\title{
فوضى الفتوى
}

\section{وأبعادها الدينية، والاجتماعية، والسياسية}

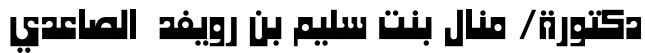

أستاذ الفقه المشارك - كلية الثريعة والار اسات الإسلامية

جامعة أم القرى - المملكة العربية السعودية ولهاية

$$
\text { بسم الله الرحمن الرحيم }
$$

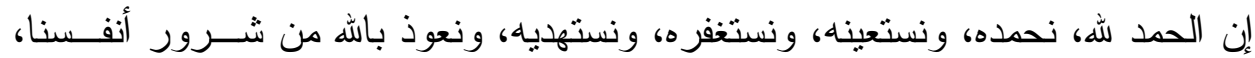

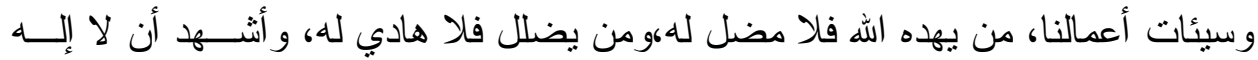

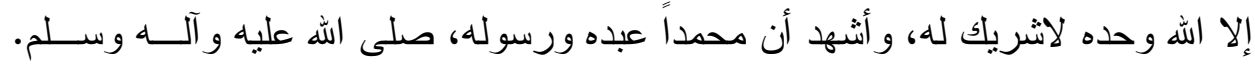
وبعد:

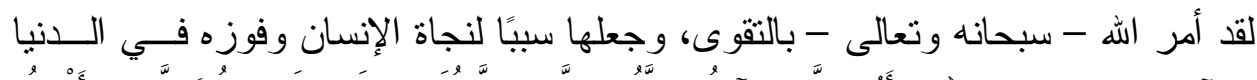

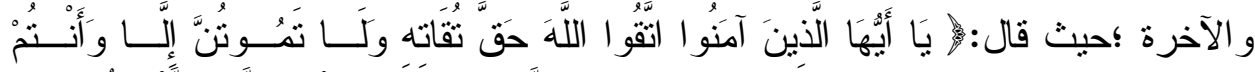

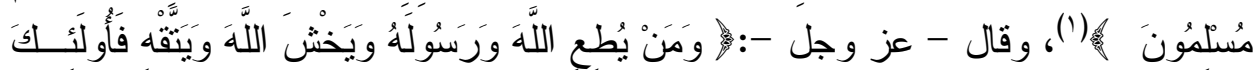

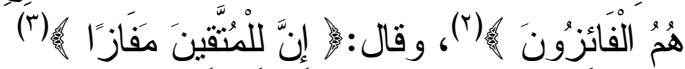

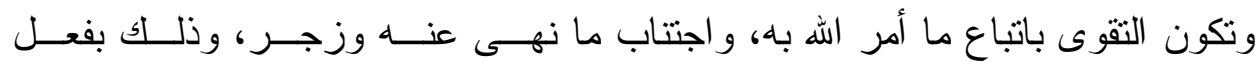
الطاعات، و اجتتاب المعاصي و المحرمات. و على كل مسلم أن بكون حريصًا على دينه

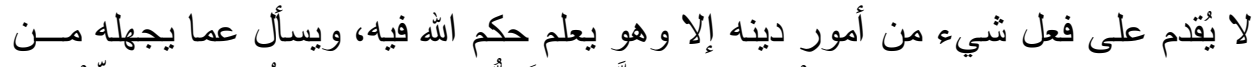

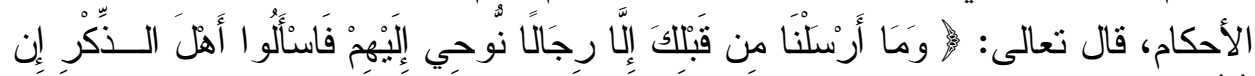

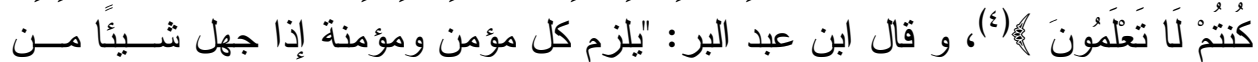

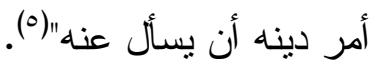

$$
\begin{aligned}
& \text { (' ) سورة آل عمران، آية r. (1. }
\end{aligned}
$$

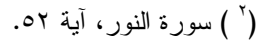

$$
\begin{aligned}
& \text { (" ) سورة النبأ، آية آس. } \\
& \text { (" (") سورة النحل، آية سأع. }
\end{aligned}
$$

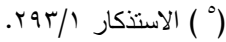




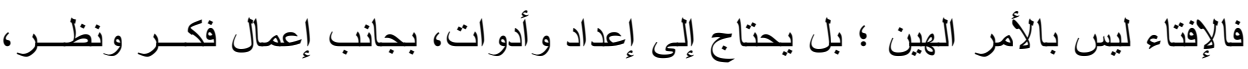

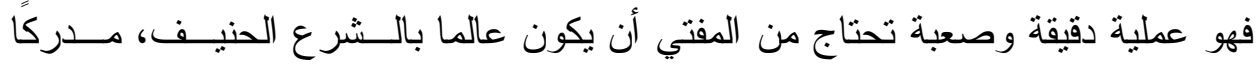

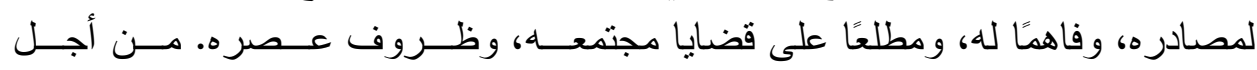

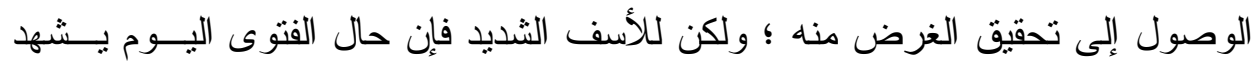

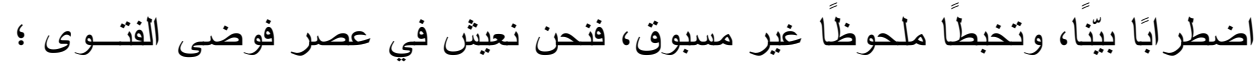

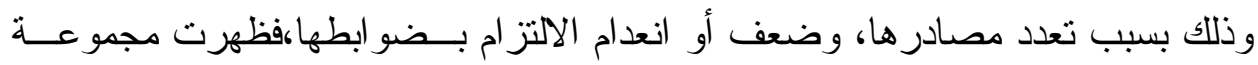

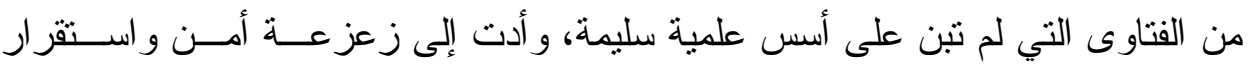

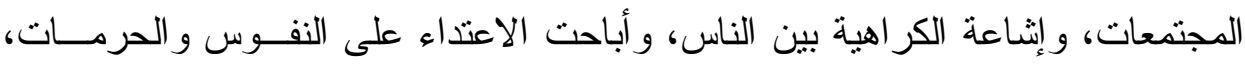

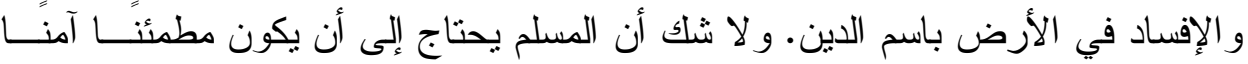

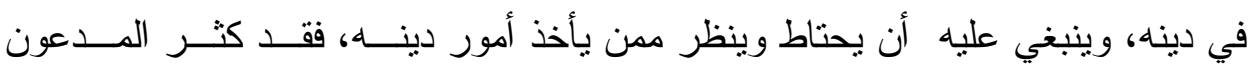

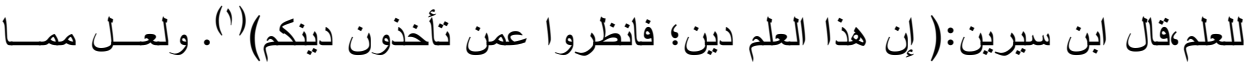

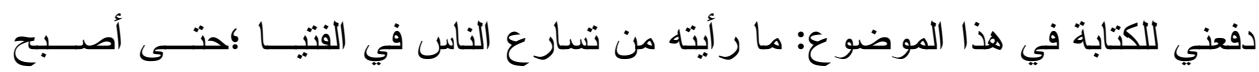

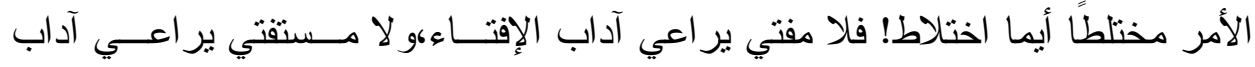

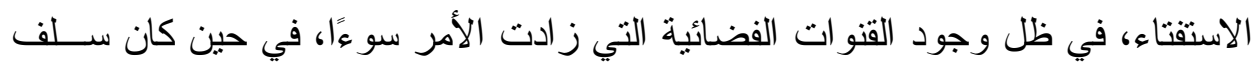

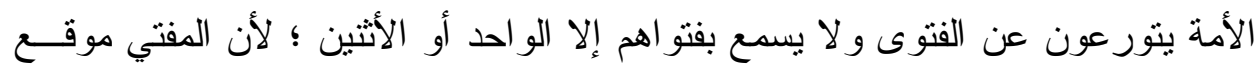

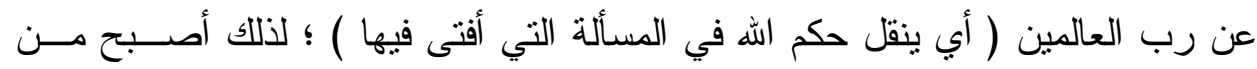

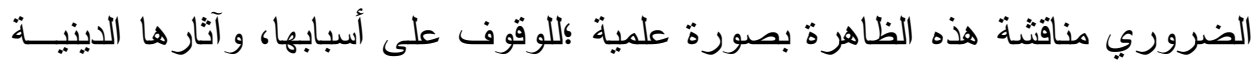
و الاجتماعية و السياسية ؛ للوصول للأمن في الفتوى ؛ فالأمن الفقهي لا يقل أهمية عـن الفن الأمن الفكري و الأسري.

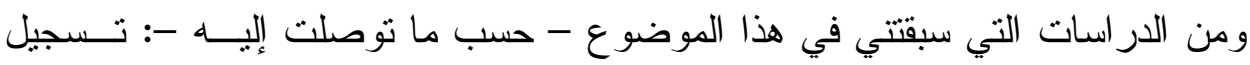

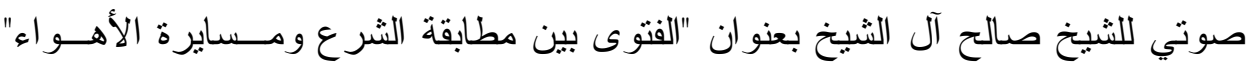
تحدث فيه عن تعريف الفتوى، و الفرق بينها وبين القضاء، و الفرق بين الاجتهاد المطلق

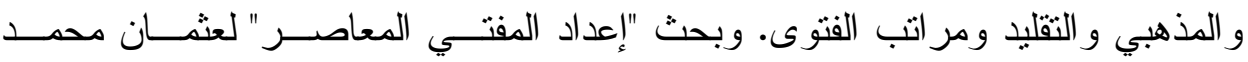

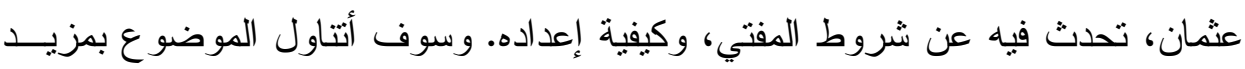

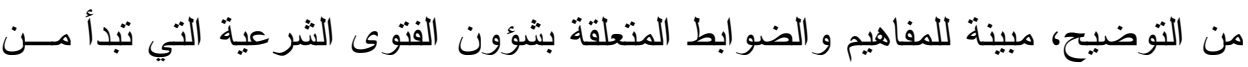

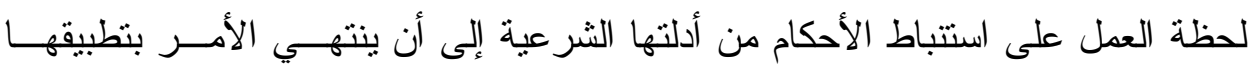
وتتزيلها على الوقائع، وربطها بمشكلات الناس وحياتهم المعاصرة. 
وقد اعتمدت في هذا البحث على المنهج الاستقرائي، ثم المنهج التحليلي. وقد اصطلحت

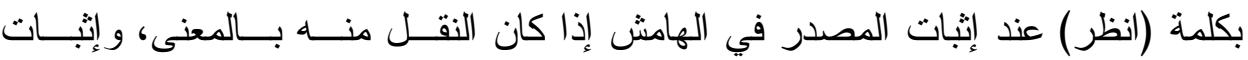

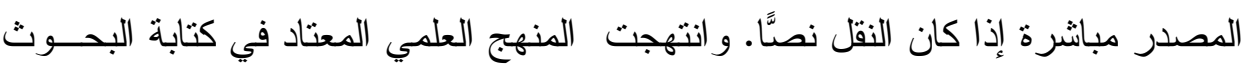

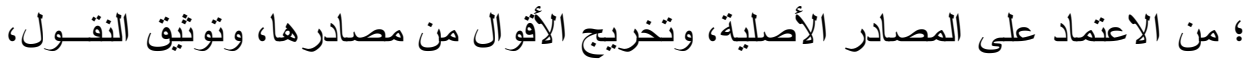

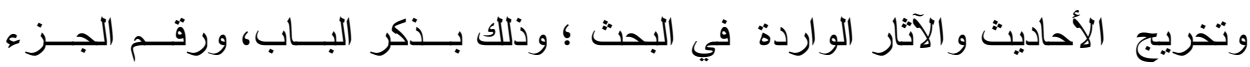

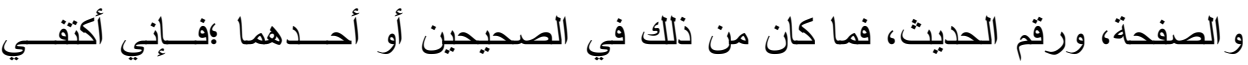

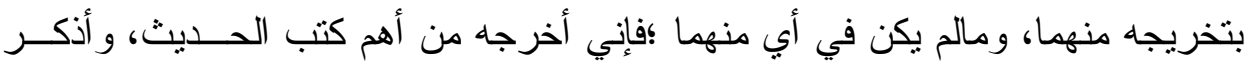

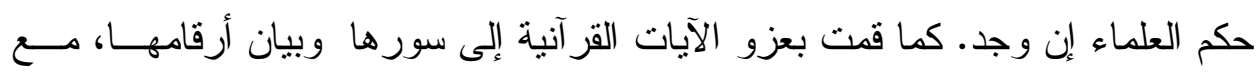

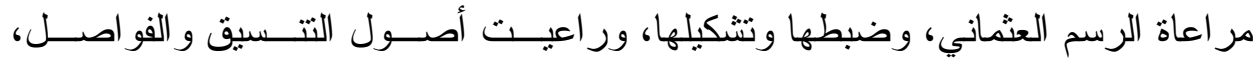

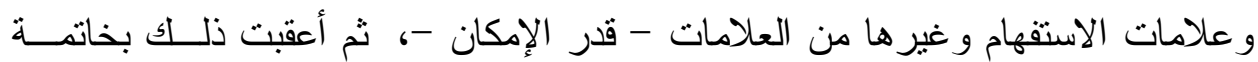

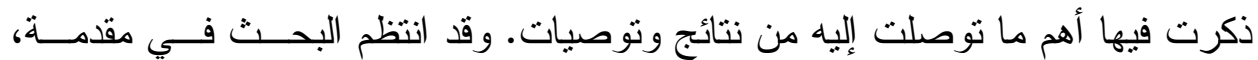

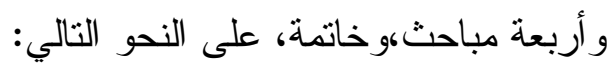

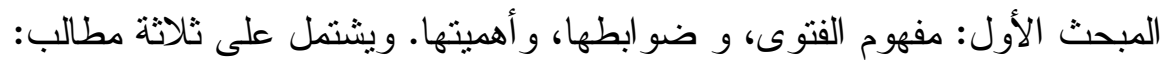

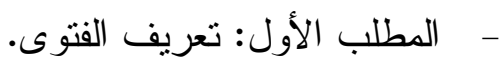

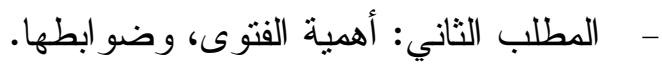
- - المطلب الثالث : آداب المفتي،و المستفتي.

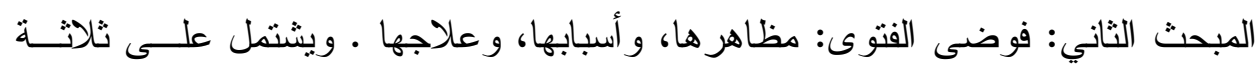
مطالب: - - المطلب الأول: مظاهر فوضى الفتوى.

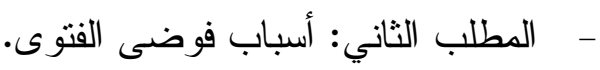
- - المطلب الثالث: علاج فوضى الفتوى. المبحث الثالث : سلطة الحاكم في تقييد الفتوى و أثرها في الأمن الفقهي.

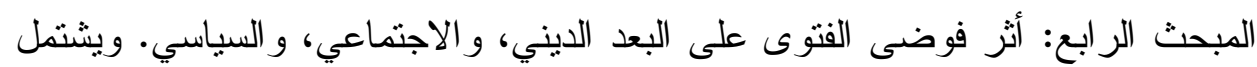
على ثلاثنة مطالب:

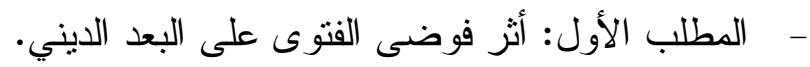

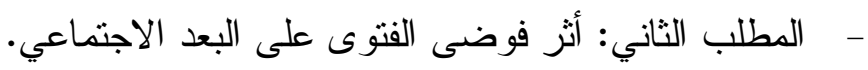
- المطلب الثالث: أثر فوضى الفتوى على البعد السياسي. 
المبحث الأول: مفهوم الفتوى، وضوابطها، وأهميتها. ويشتمل على ثلاثة مطالب: المطلب الأول: تعريف القتوى. تعريف الفتوى لغة:

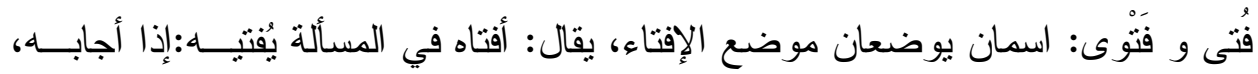

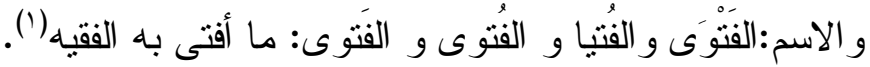

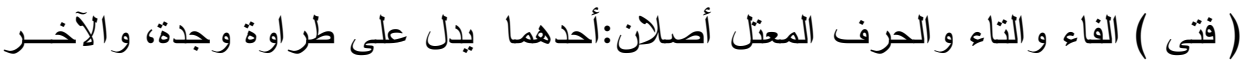

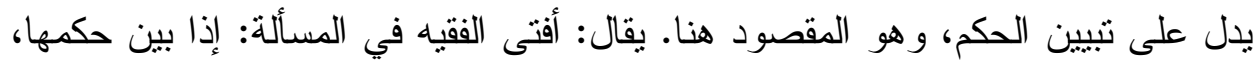

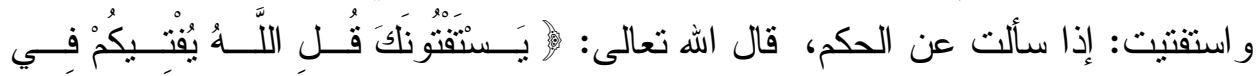

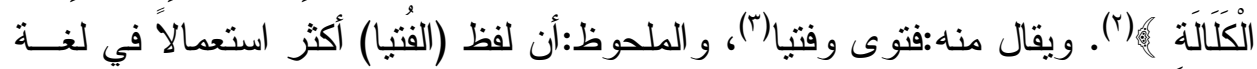
العربَ و أفصح من لفظ (الفتوى) (أ). تعريف الفتوى اصطلاحًا:

عرف العلماء الإفتاء بعدد من التعريفات المنقاربة في المعنى ؛ ومنها:

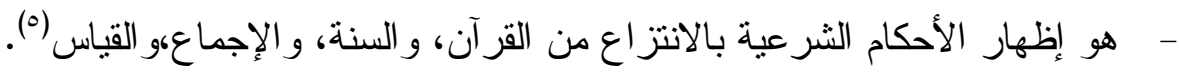

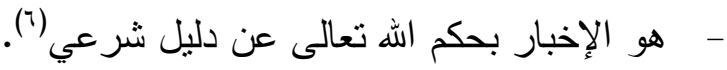

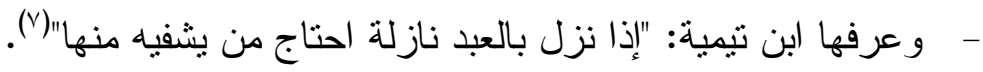

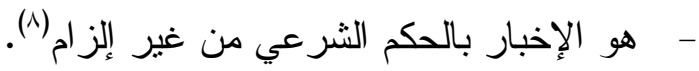

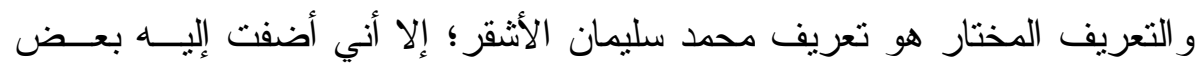

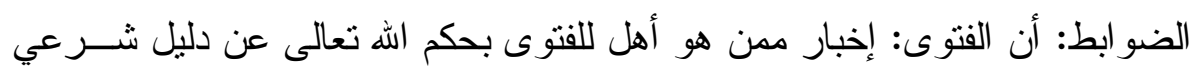

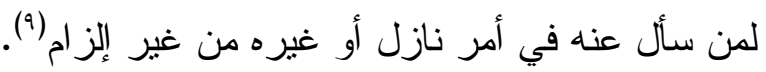

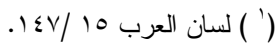

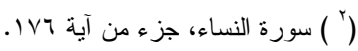

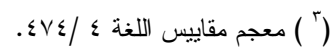

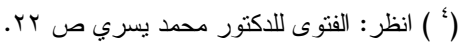

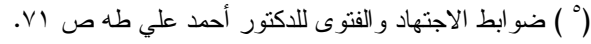

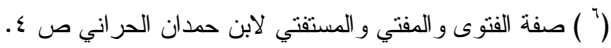

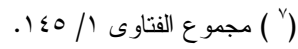

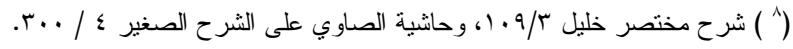

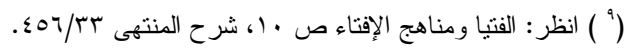




\section{شرح التعريف:}

- الإخبار :هو الإعلام بالثيء(') يدخل فيه الفتوى و غيرها.

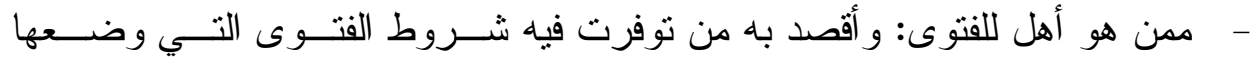

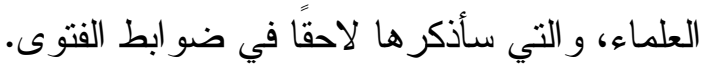

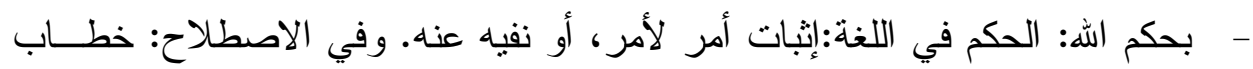

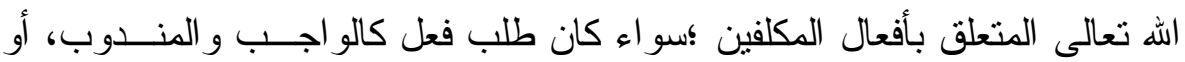

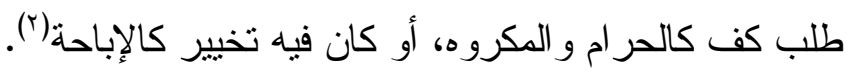

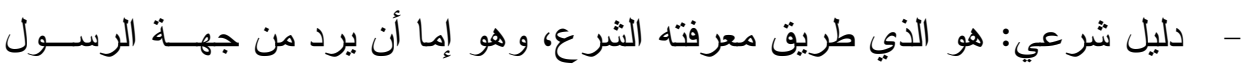

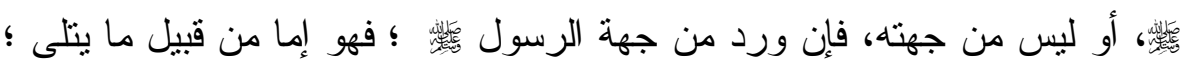

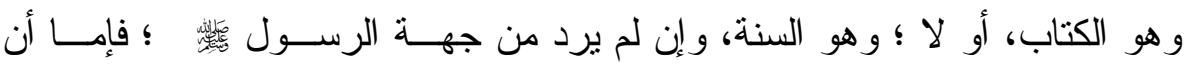

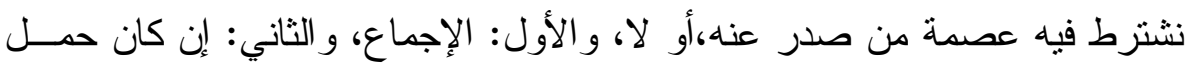

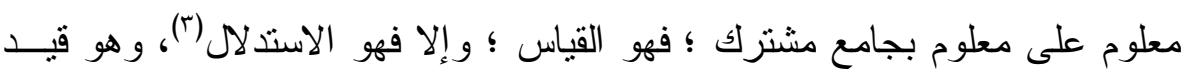

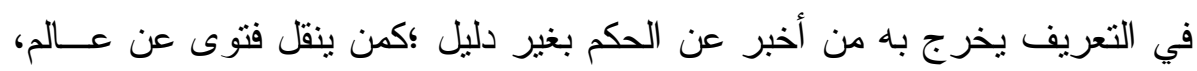

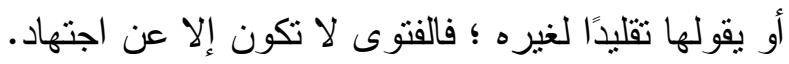

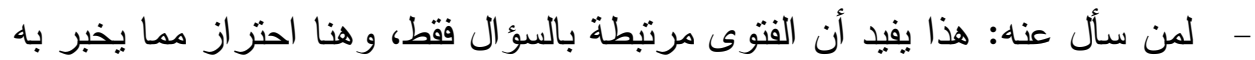

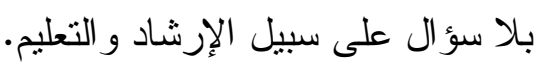

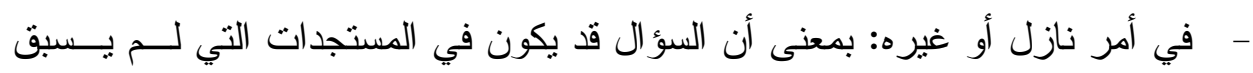
حدوثها، وقد تكون في أمر ليس بمستجد؛ ولكن السائل يجهله،أو أنه يختلف بحسب فئ فئ حال السائل ؛كالأمور المتعلقة بالطلاق و اليمين و غير هما.

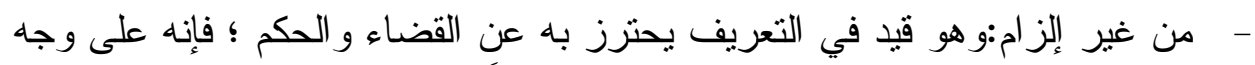

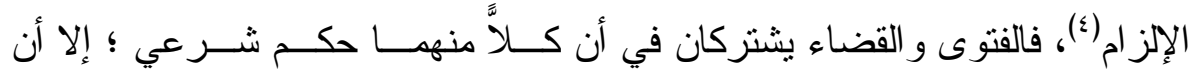

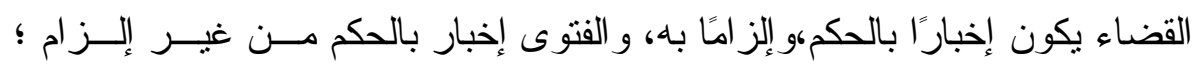
بمعنى: أن الحكم في القضاء لا يجوز نقضه بحكم آخر، في حين أن الفتوى قابلــــة

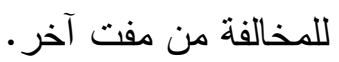




\section{المطلب الثاني: أهمية الفتوى، وضو ابطها.}

أهمية الفتوى:

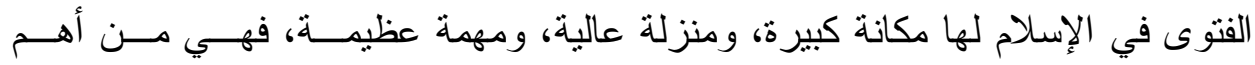

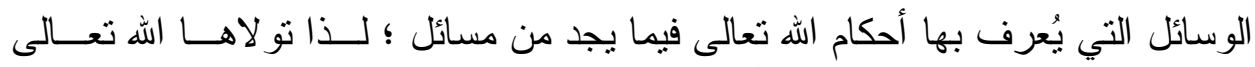

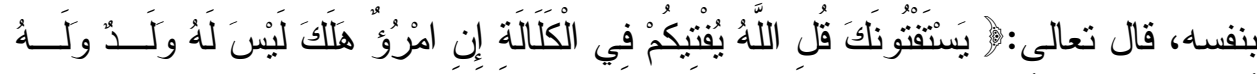

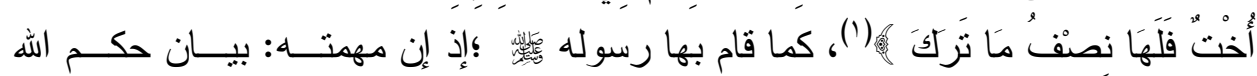

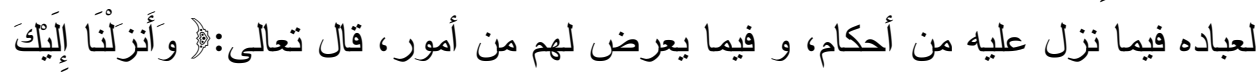

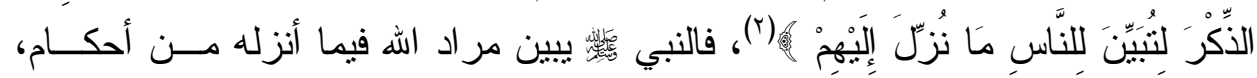

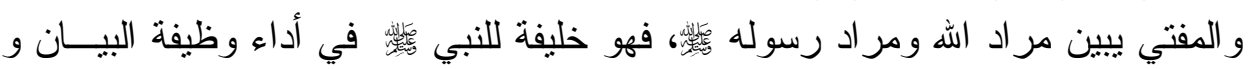

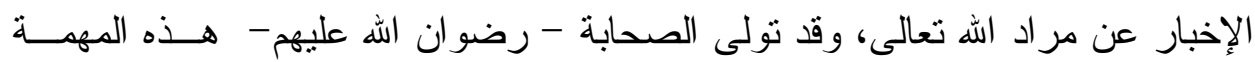

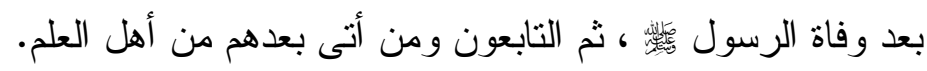

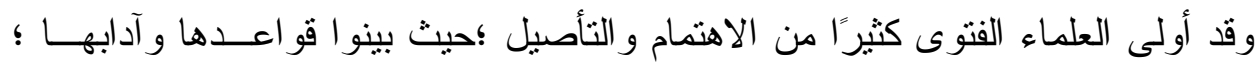
لأن المفتي خطره عظيم؛ فإنه موقع عن الله ورسوله، زاعم أن الله أمر بكذا وحرم كذا،

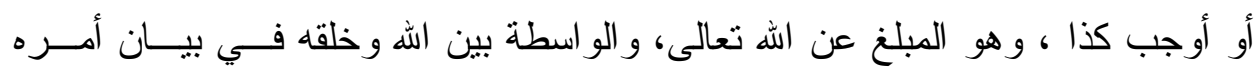

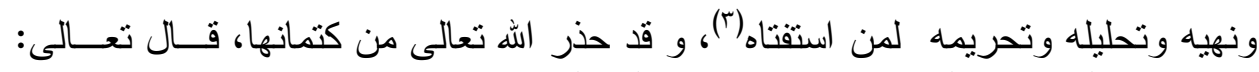

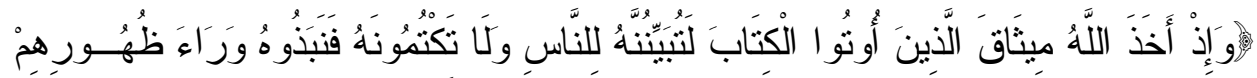

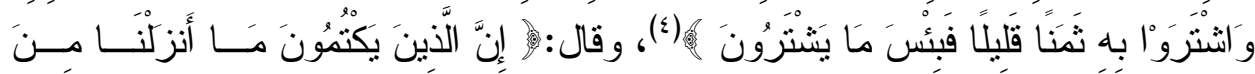

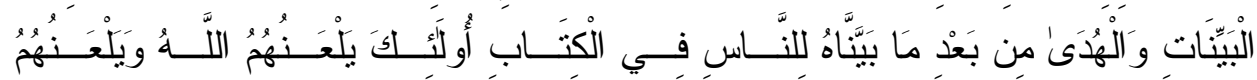

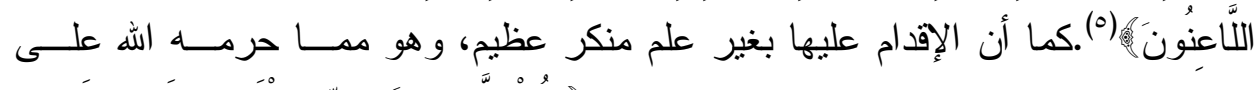

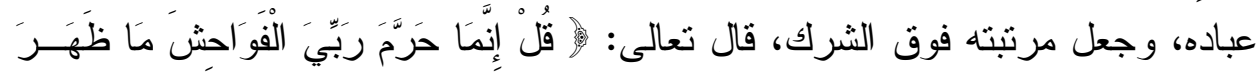

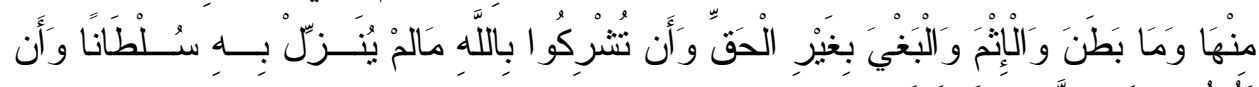

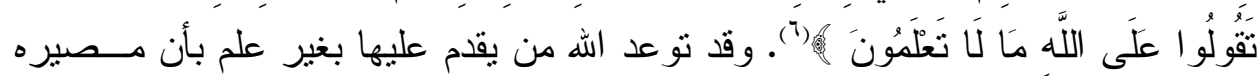

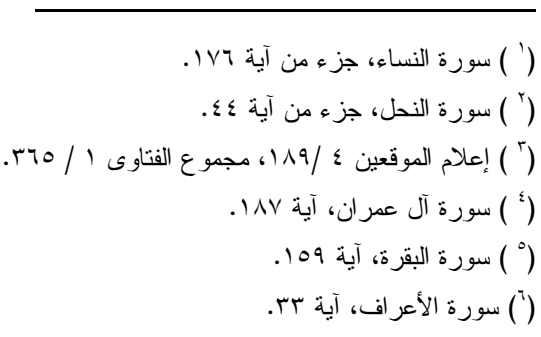




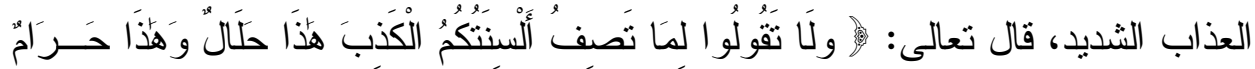

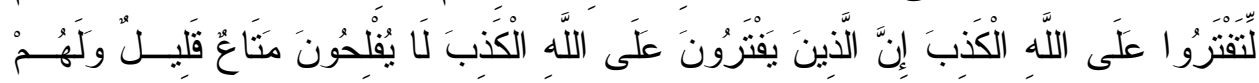

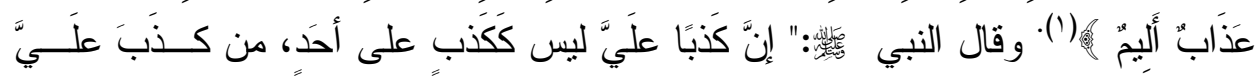

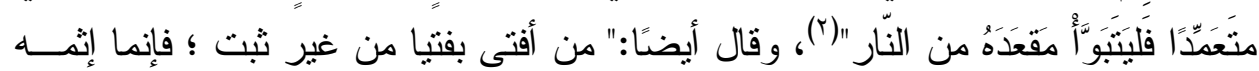

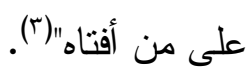
لذلك كان كثير من الصحابة لا يجيب عن مسألة حتى يأخذ رأي صاحبه، وكان الخلفاء

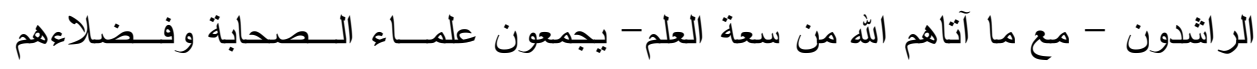

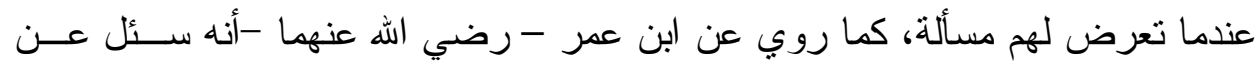

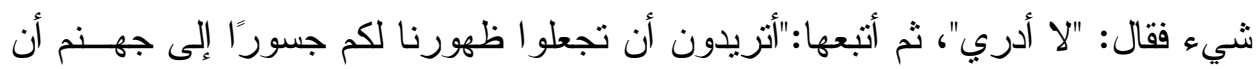

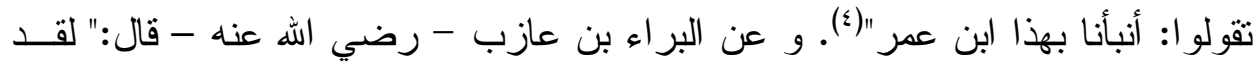

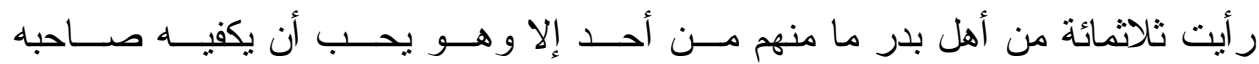

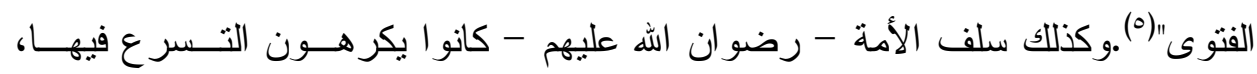

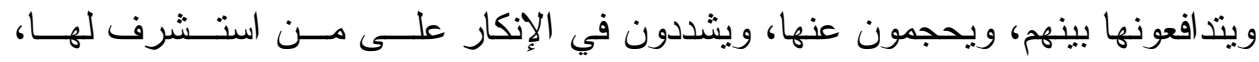

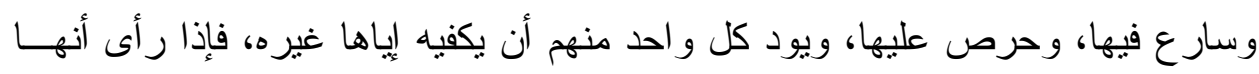

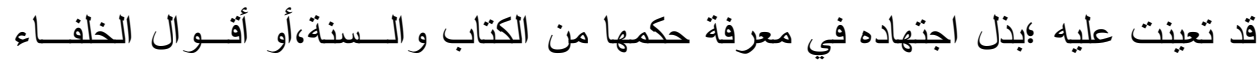

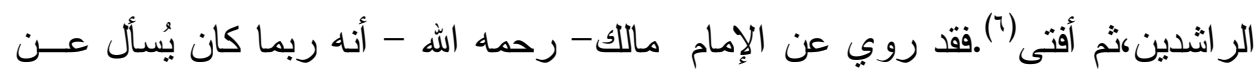

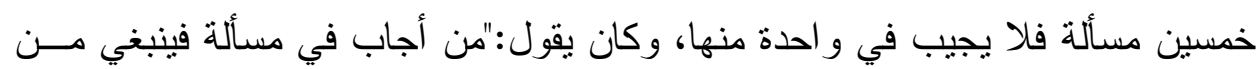

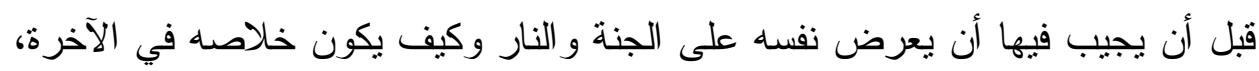

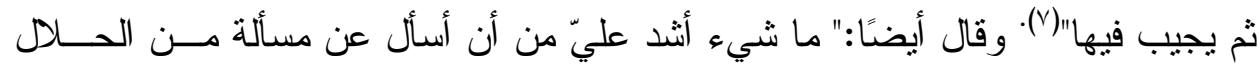

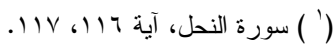

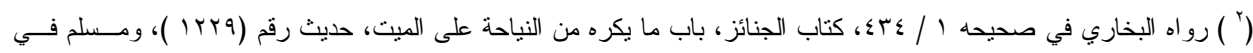

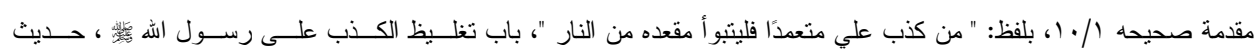

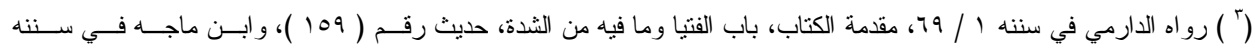

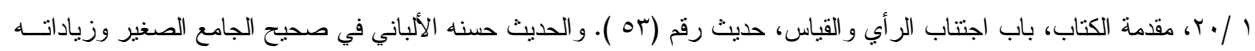

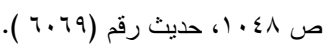

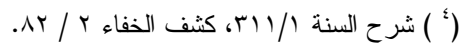

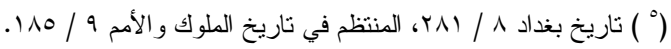

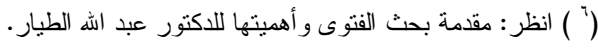

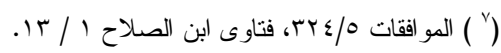


و الحر ام؛ لأن هذا هو القطع في حكم اللههولقد أدركنا أهل العلم ببلــدنا وإن أحــدهم إذا

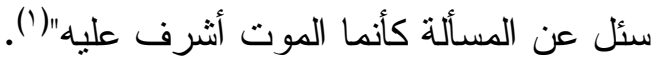
ضوابط الفتوى : لن

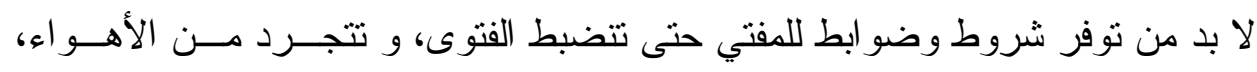

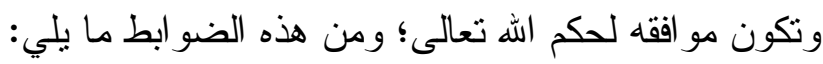

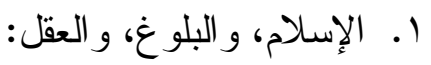

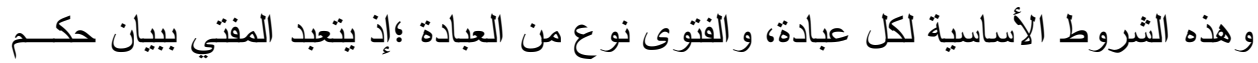

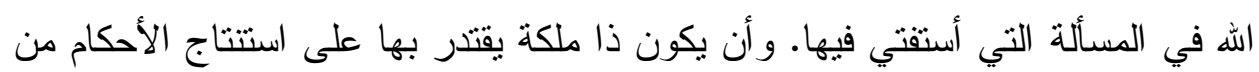

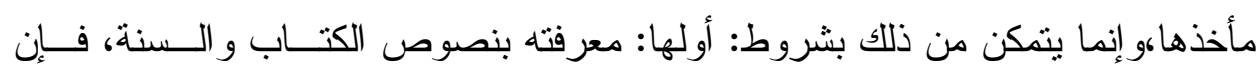

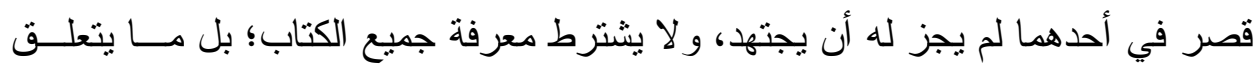

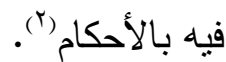

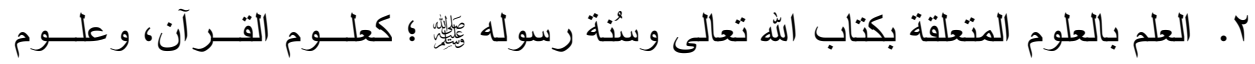

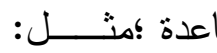

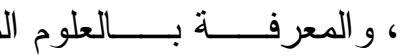

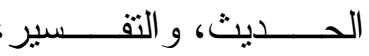

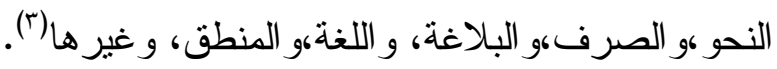

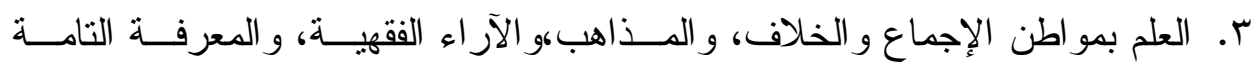

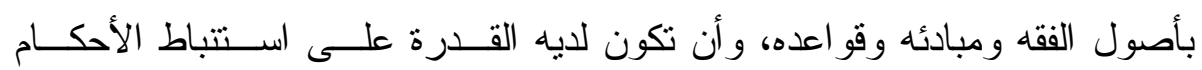

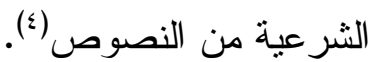

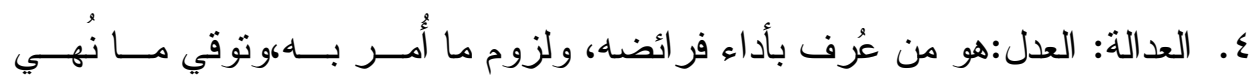

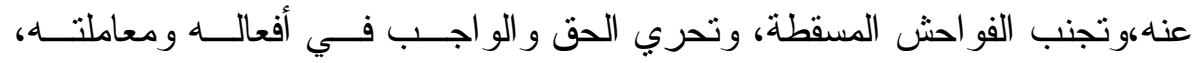

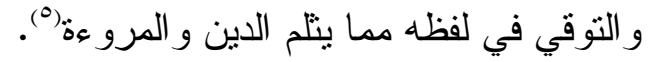

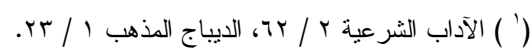

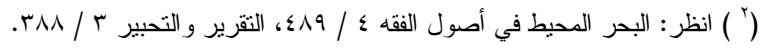

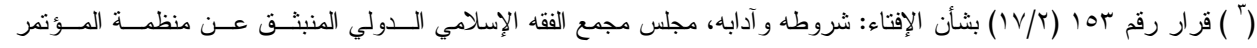

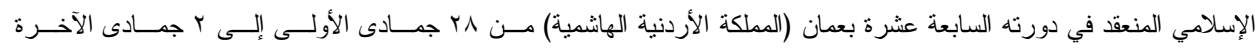


ه. الرجوع إلى أهل الخبرة في التخصصـات المختلفة لتصور المسألة المسؤول عنهــــا

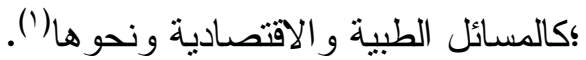

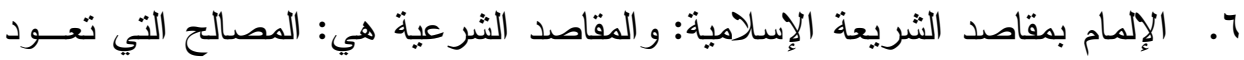

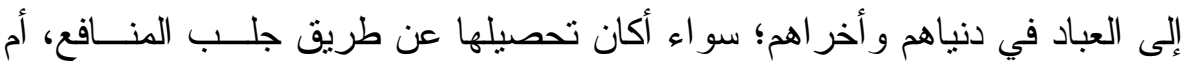

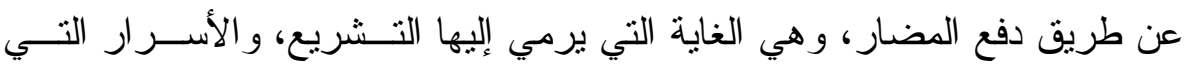

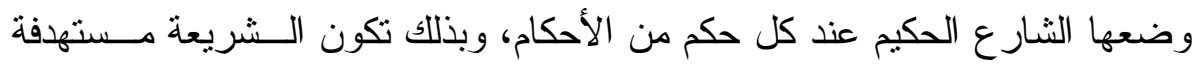
تحقيق مقصد عام ؛ وهو إسعاد الأفراد و الجماعة، وحفظ النظام، وتعمير الدنيا بكل

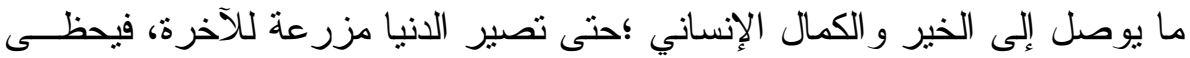

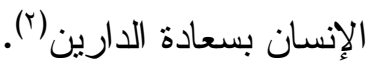

ونجد أن أحكام الثريعة في مجموعها معللة، وأن ور اء ظو اهر ها مقاصد هدف الــشرع إلى تحقيقها، وأن من أسماء

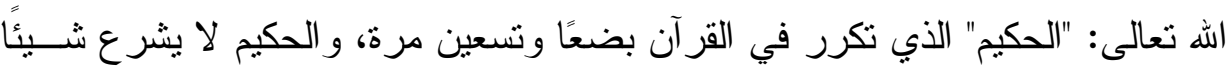

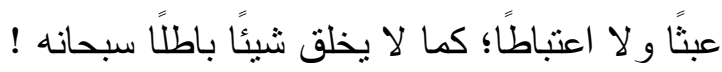

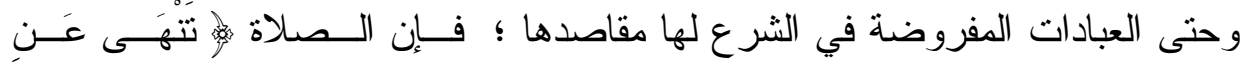

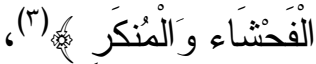

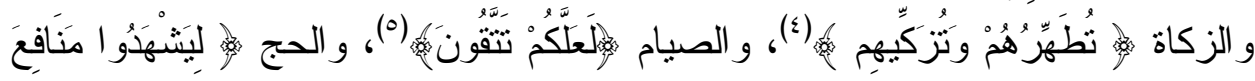

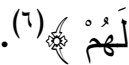
فيجب على من يتصدى للفتوى أن يدرك مقصود الشرع من التكاليف؛ حتى يعمل علــى

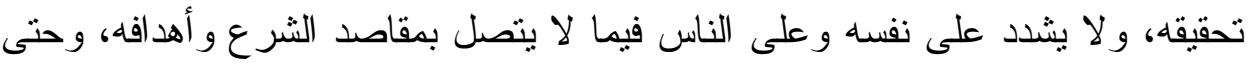

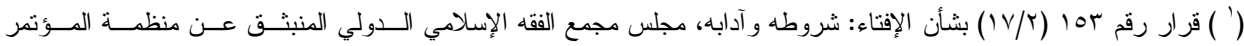

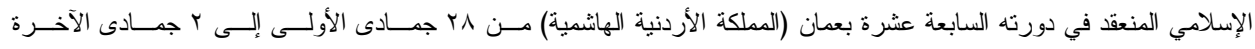

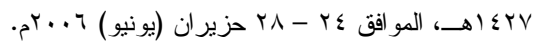

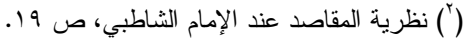

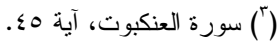

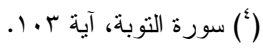

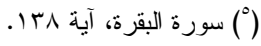

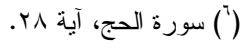


لا يكون قصده مخالفًا لقصد الثار ع ؛ فلا نؤتي أعماله ثمار ها، ويكون أخذه بالمـشروع

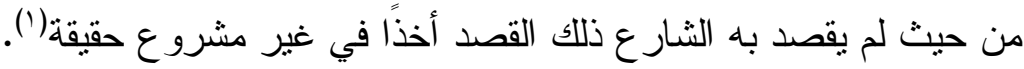

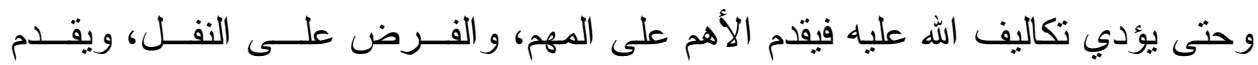

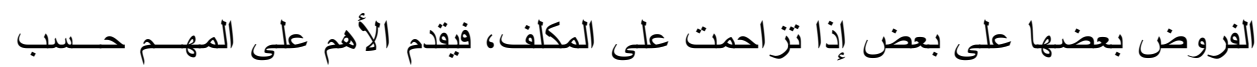
مقاصد الشار ع من تزتيب الأحكام حسب أهميتها (؟). V. الإلمام بقو اعد ودرجات المصالح من حيث الكبر و الأهمية:

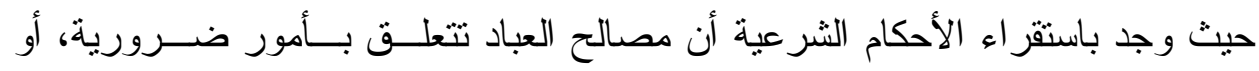

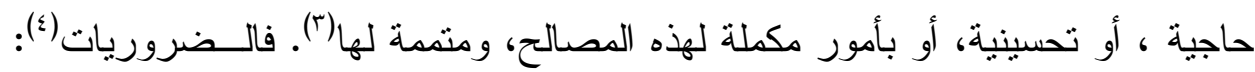

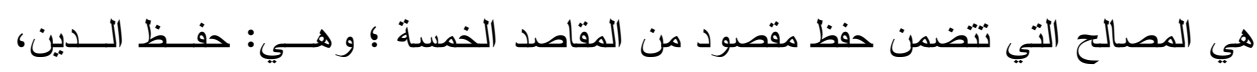
و النفس، و العقل،و المال، و النسب.

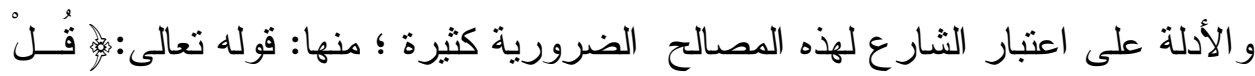

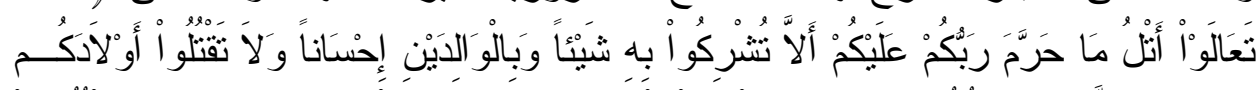

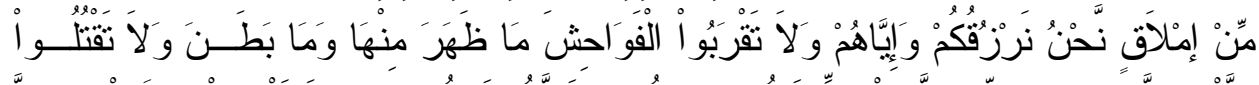

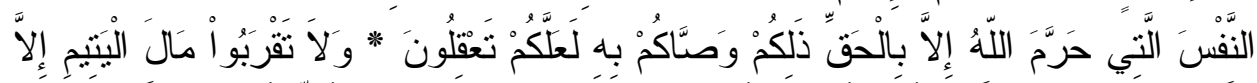

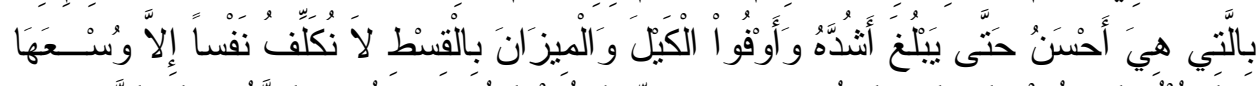

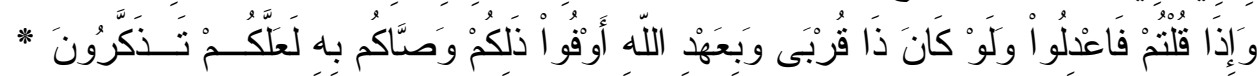

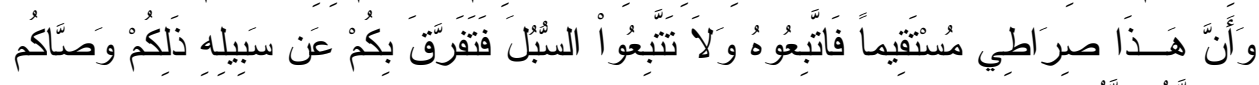

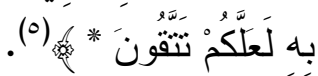

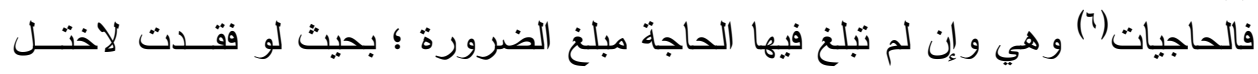

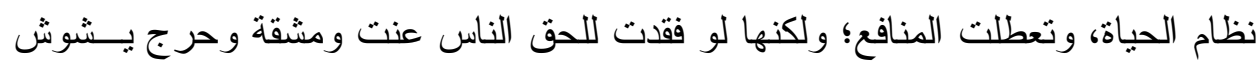

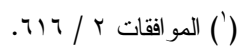

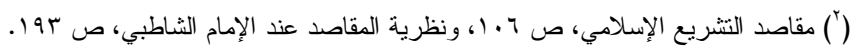

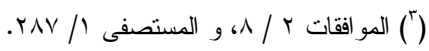

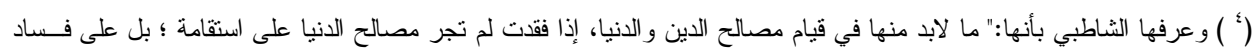

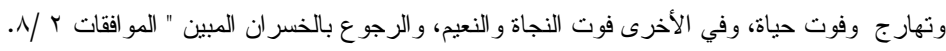

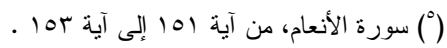

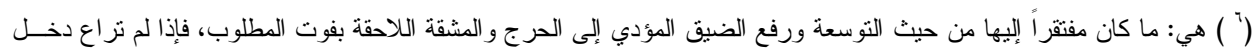

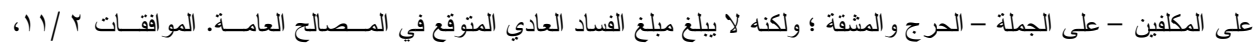

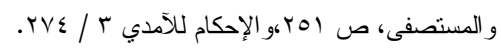


عليهم عباداتهم،ويعكر عليهم صفو حياتهم،وربما أدى ذللك إلى الإخــلهل بالــضروريات

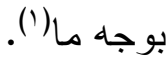

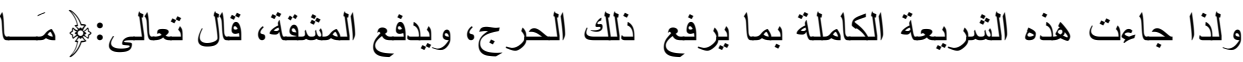

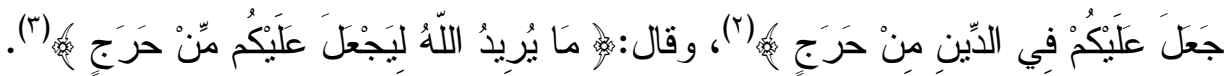

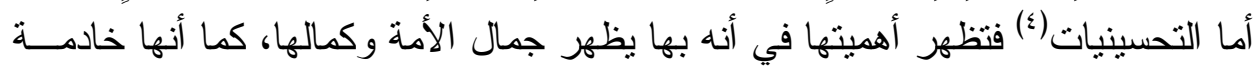

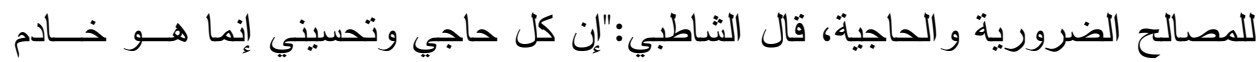

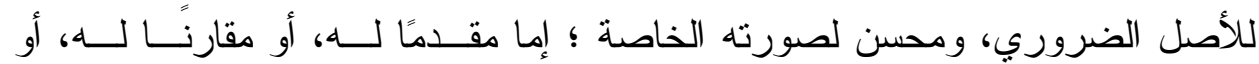
تابعًا....... (0) ومن أمنلة اعتبار الثشار ع لهذه التحسينيات: حث الإسلام على كل ما يتعلق بالطهارة في

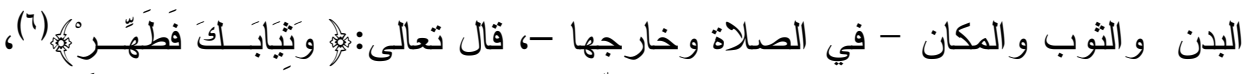

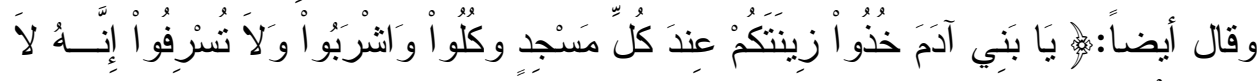

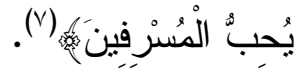
^. الإلمام بحاجة العصر وضرورياته (فقه الو اقع):

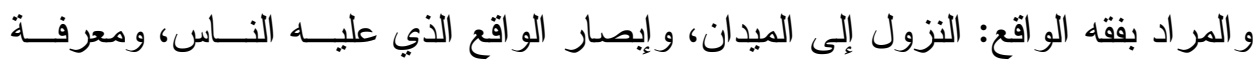

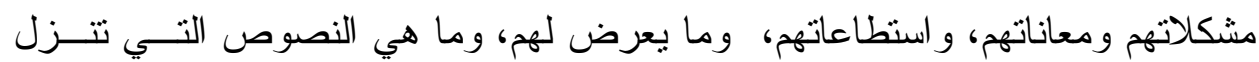

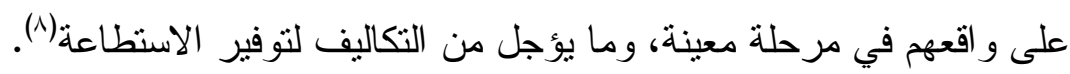

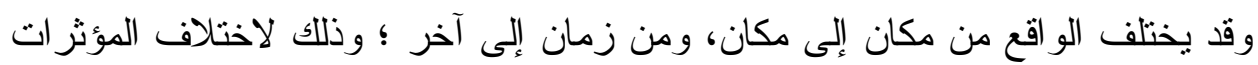
و المستجدات وتتوعها.

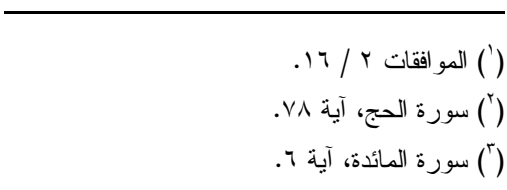

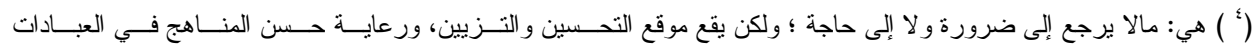

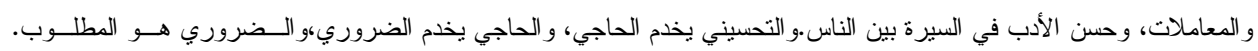

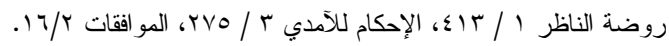

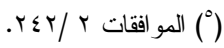

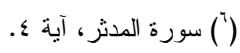

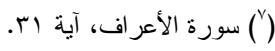

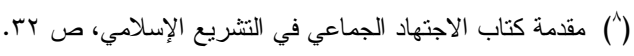




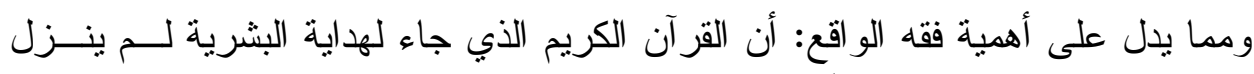

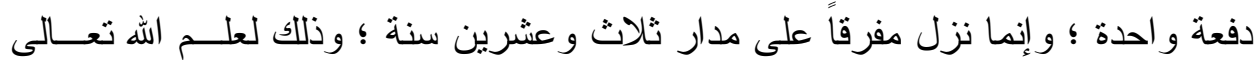

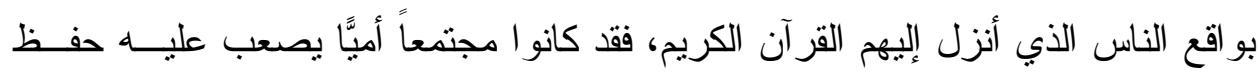

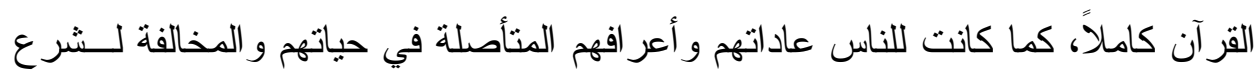

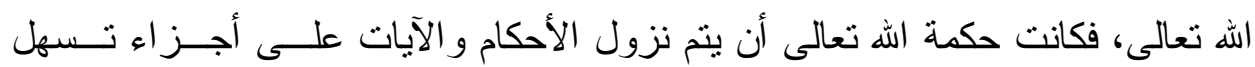

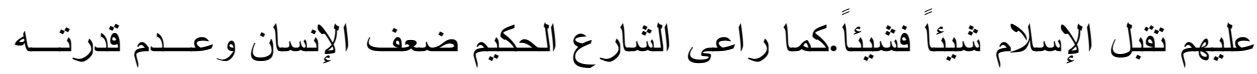

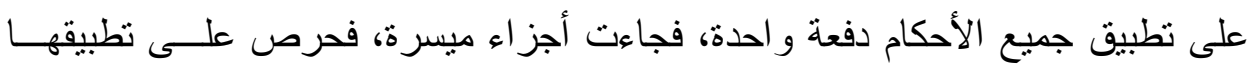

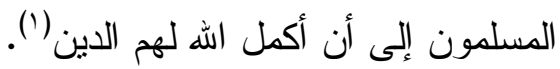

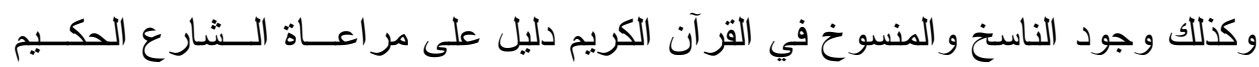

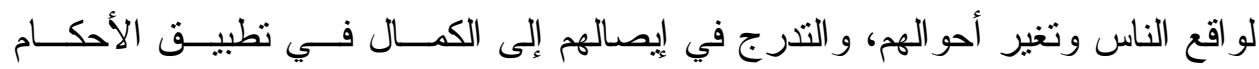

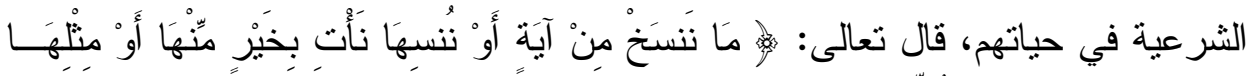

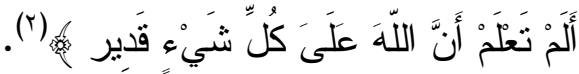
قال القرطبي - رحمه الله -: " لفظة (خير) هنا صفة تفضيل فيل، و المعنى: بأنفع لكم أيهــا

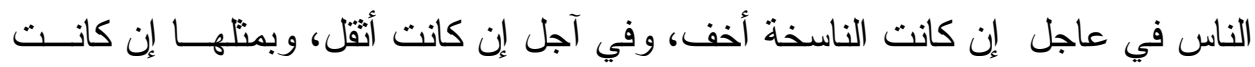

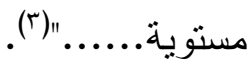

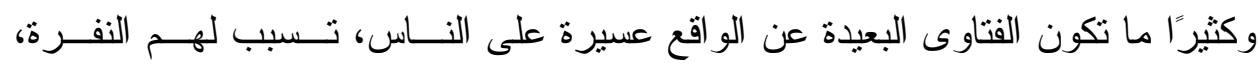

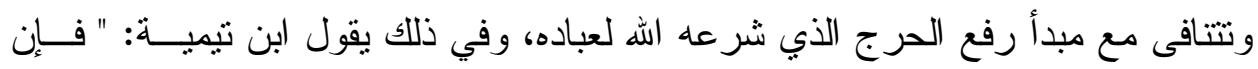

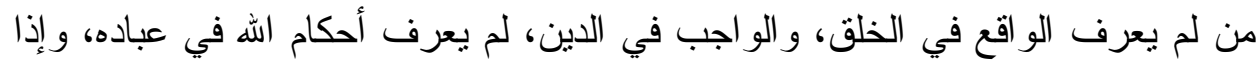

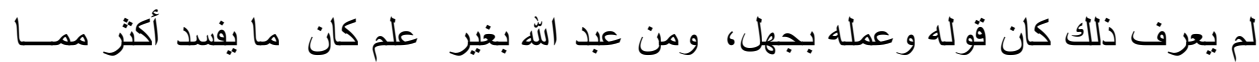

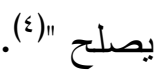

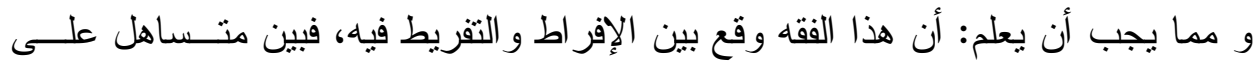

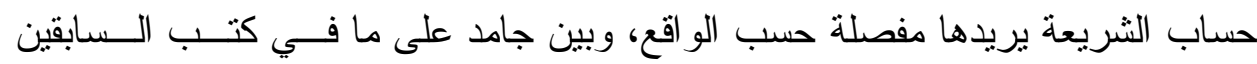

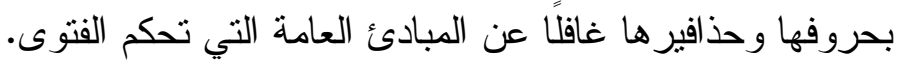

$$
\begin{aligned}
& \text { (') فقه الموازنات الدعوية، ص ع ع. }
\end{aligned}
$$

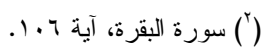

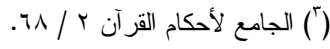

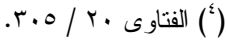




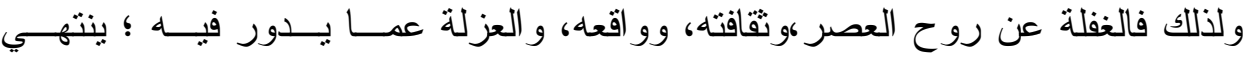

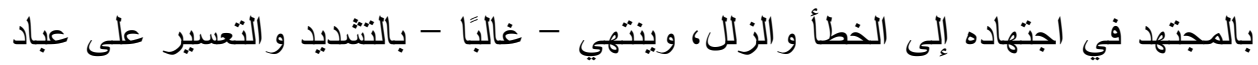
الله حيث يسر الله عليهم ('). المطلب الثالث : آداب المفتي،و المستفتي.

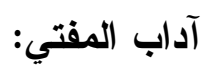
هناك آداب ينبغي أن يتحلى بها المفتي ذكرها العلماء في كتبهم منها:

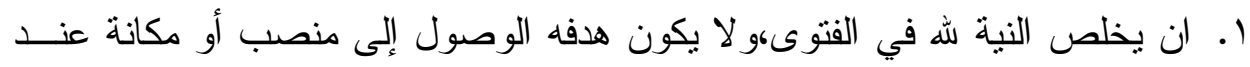

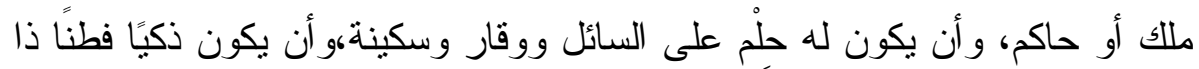

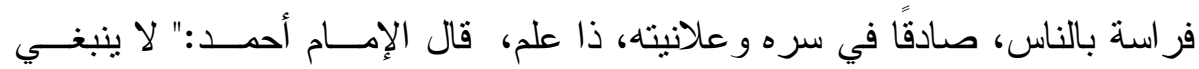

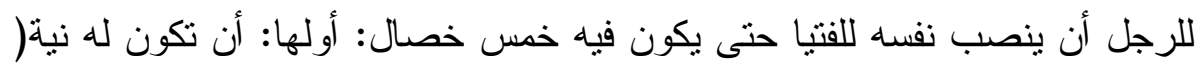

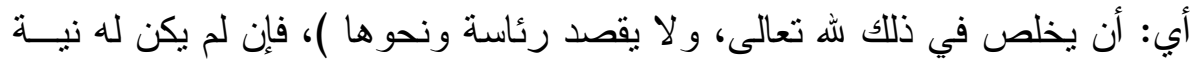

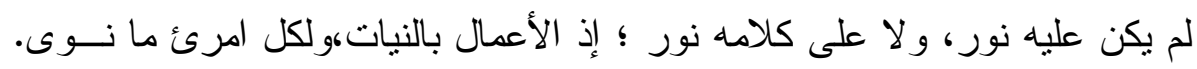

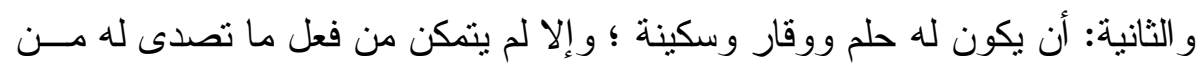

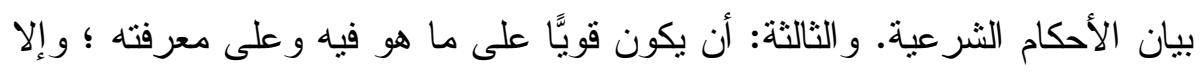

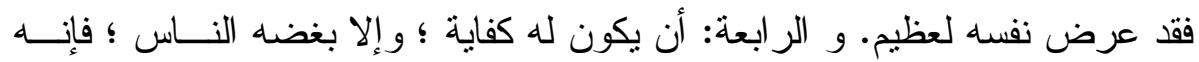

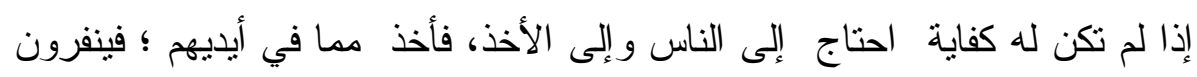

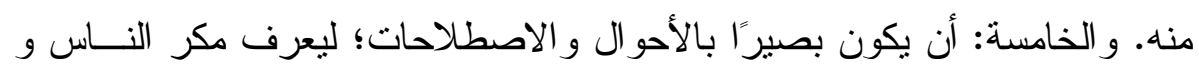

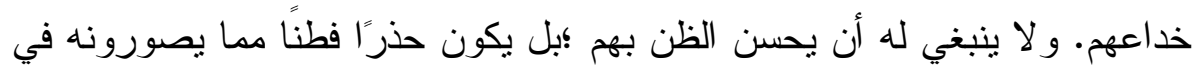

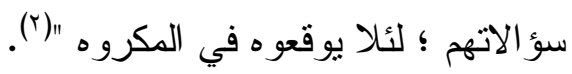

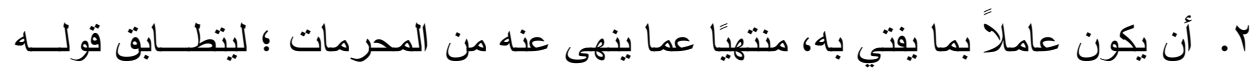

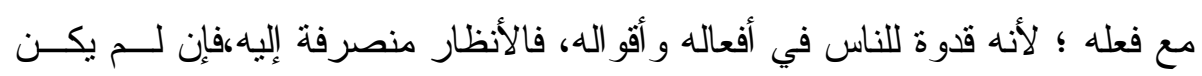

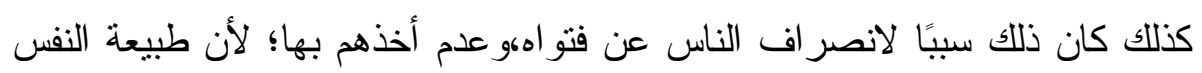

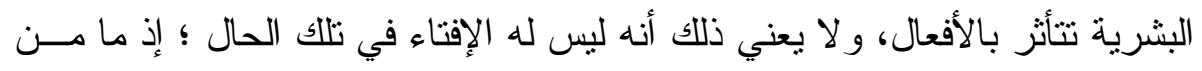




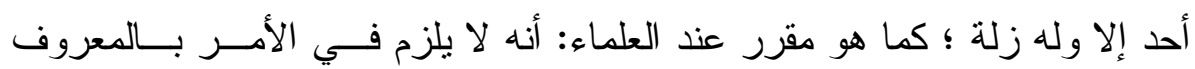

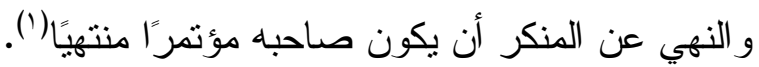
r. ينبغي للففتي أن يحسن زيه، مع التقيد بالأحكام الثرعية في ذلك، فئرئ فير اعي الطهارة

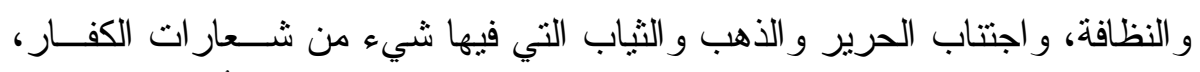

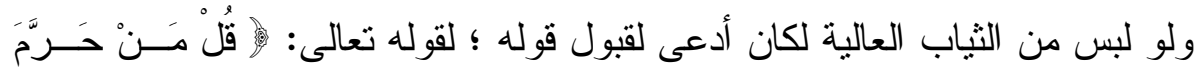

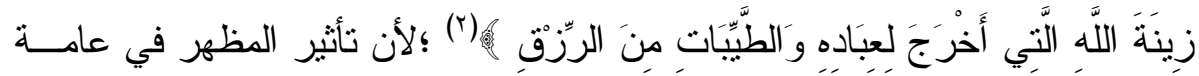
الناس لا ينكر، وهو في هذا الحكم كالقاضي (َ).

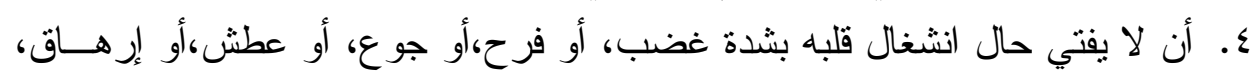

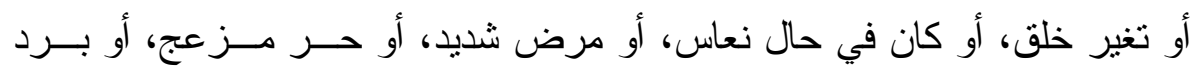

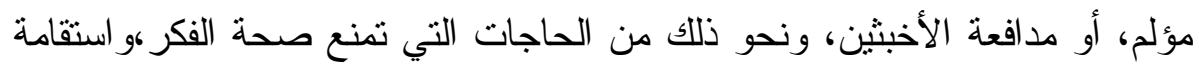

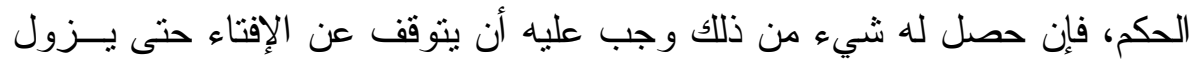

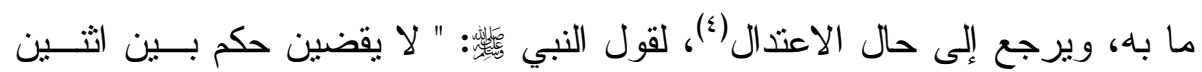
و هو غضبان" (0). ه. على المفتي كتمان أسر ار المستقتين، فهو بطلع من أسرار الناس وعور اتهم على ما

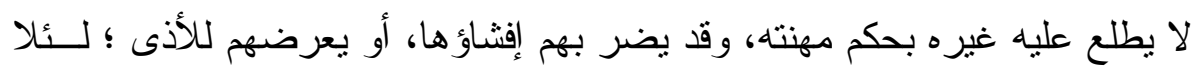

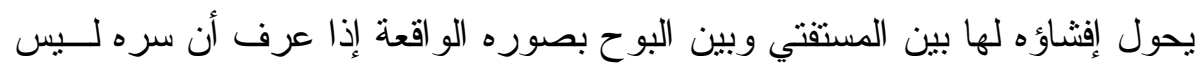

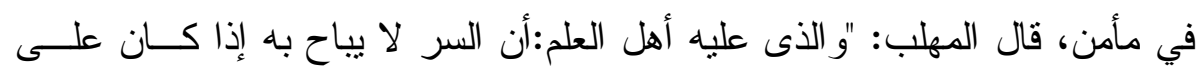

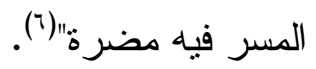

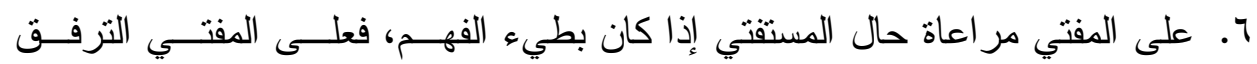

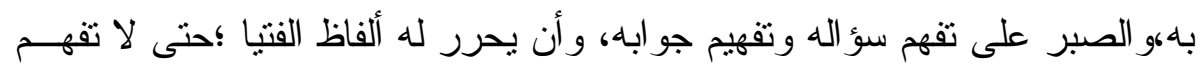

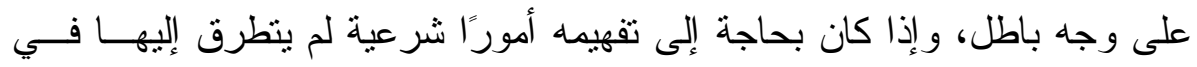

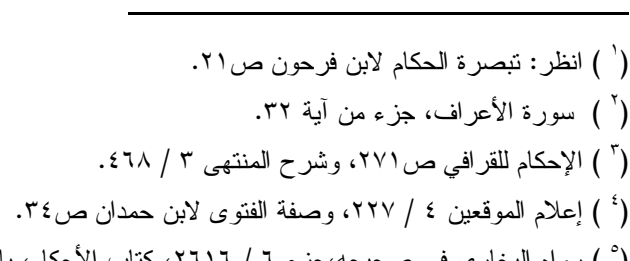

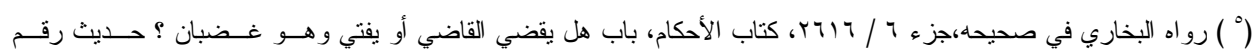




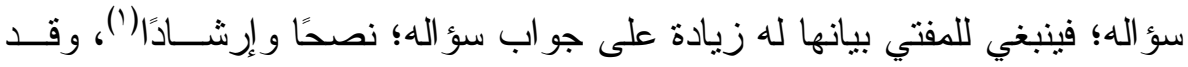

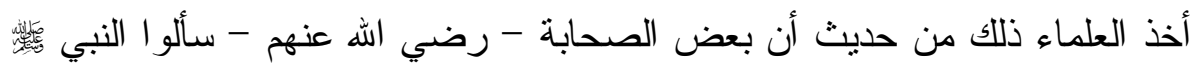

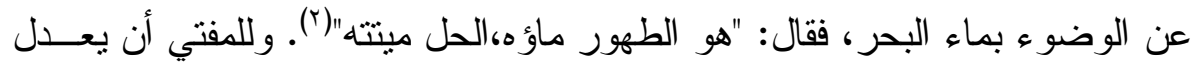

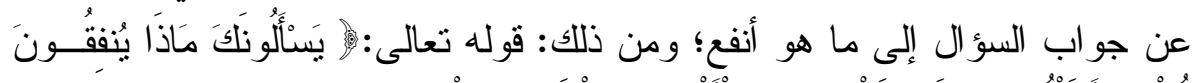

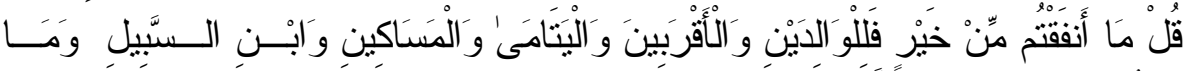

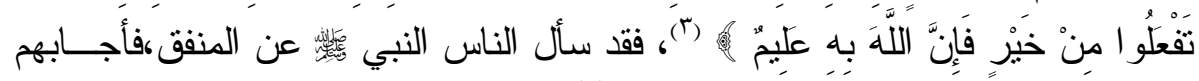

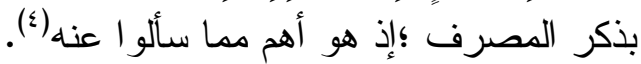

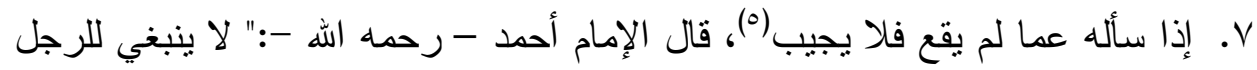

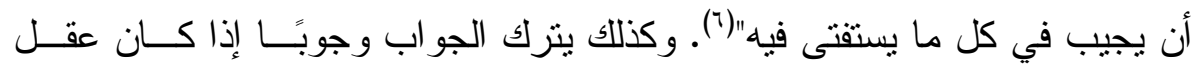

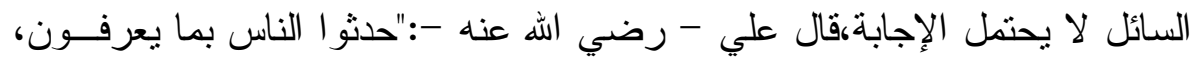

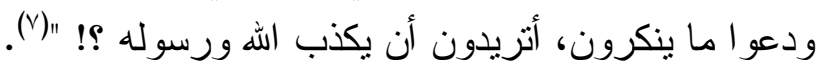

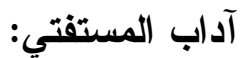

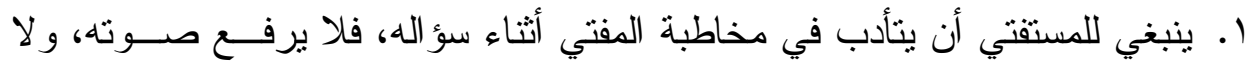

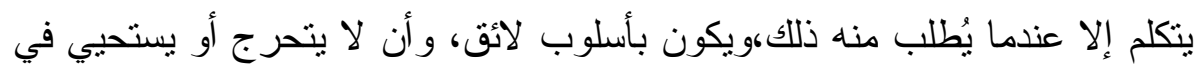

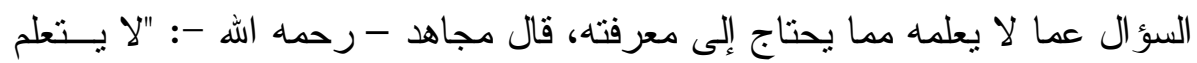

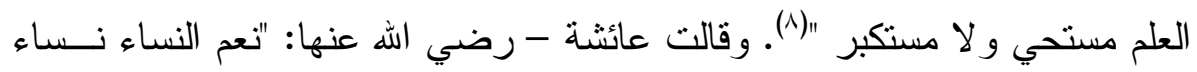

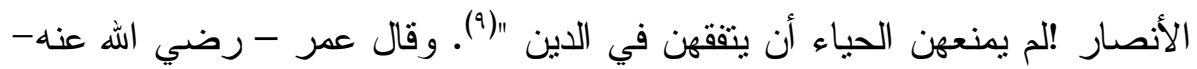

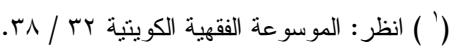

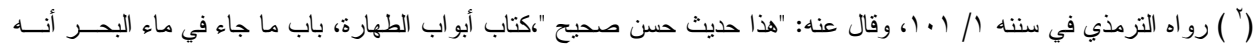

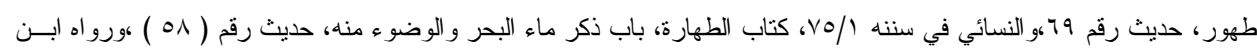

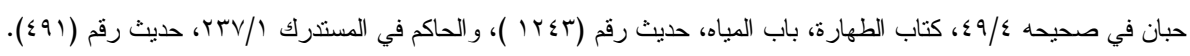

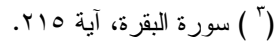

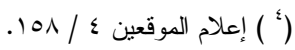

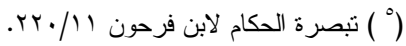

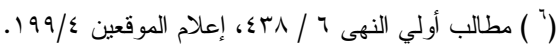

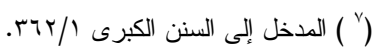

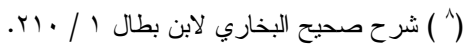

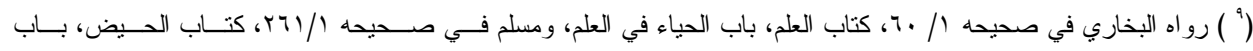

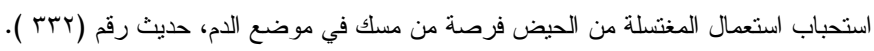




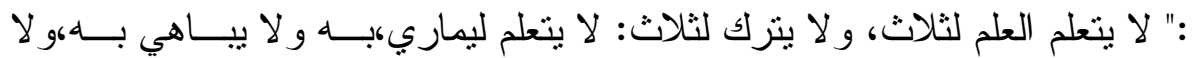

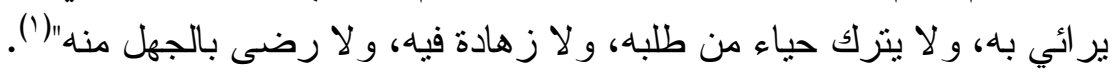

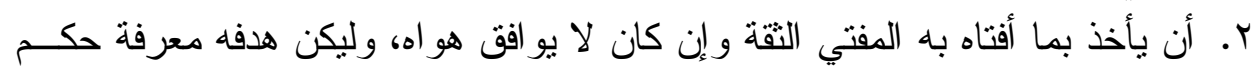

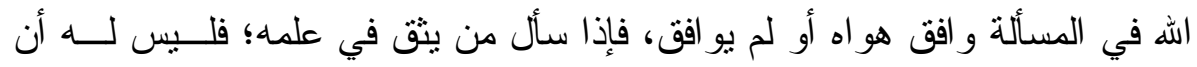

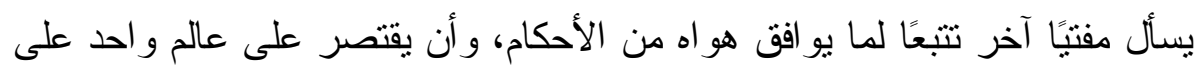

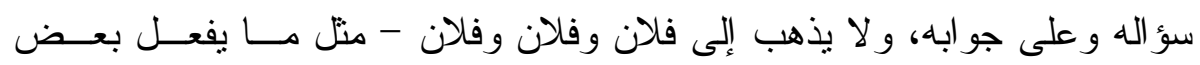

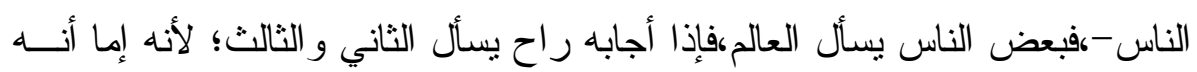

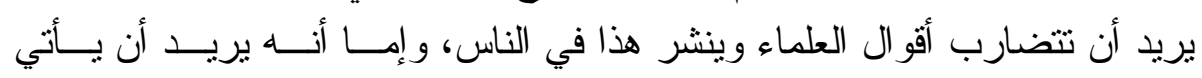

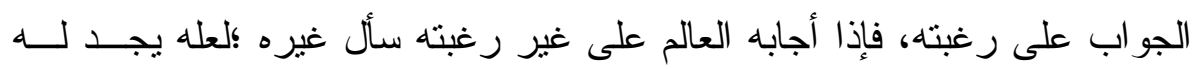

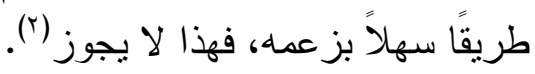

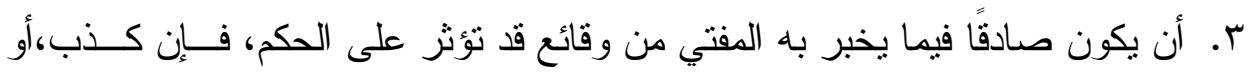

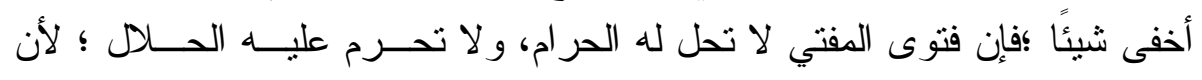

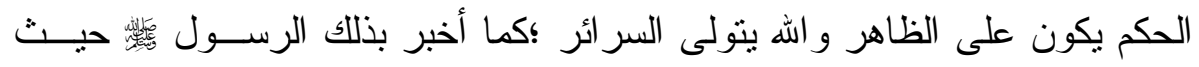

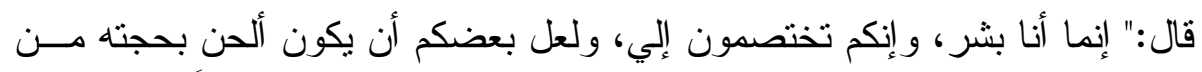

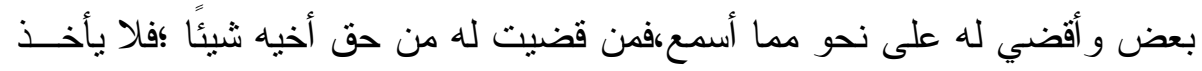

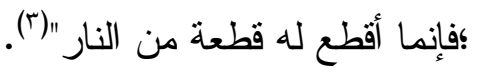

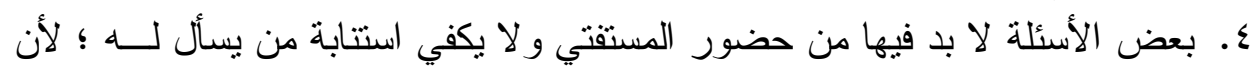

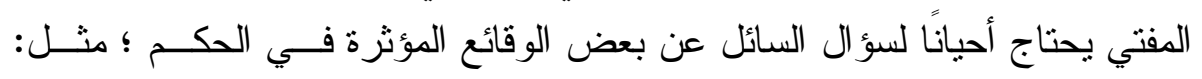

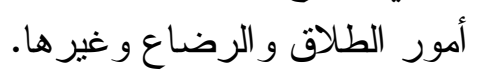

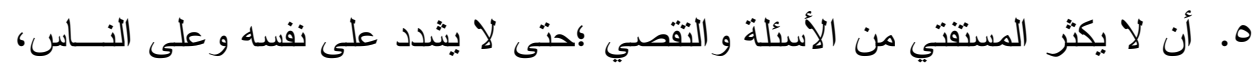

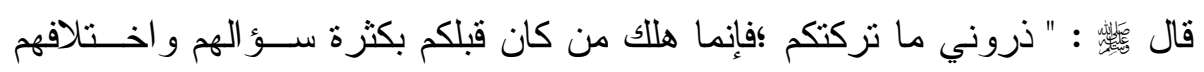

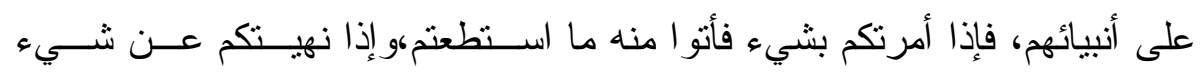

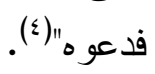

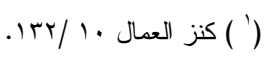

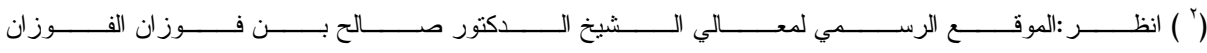
.ht t ps://mww.al f awzan.af org.sa

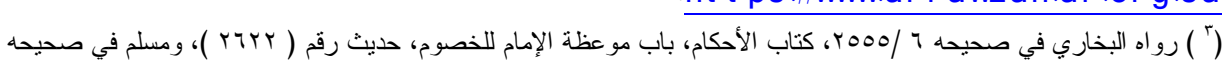

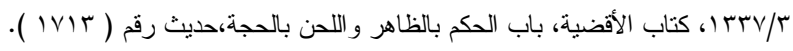

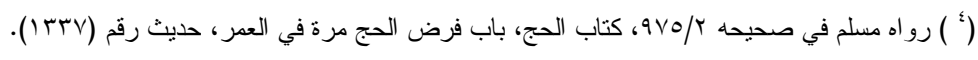


المبحث الثاني: فوضى الفتوى: مظاهرها، وأسبابها، وعلاجها،وأثرها علــى الأمــن الفقهي، ويشتمل على ثلاثة مطالب: المطلب الأول: مظاهر فوضى الفتوى.

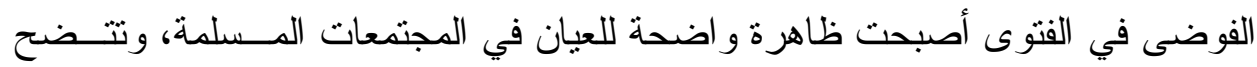
مظاهر هذه الظاهرة فيما يلي:

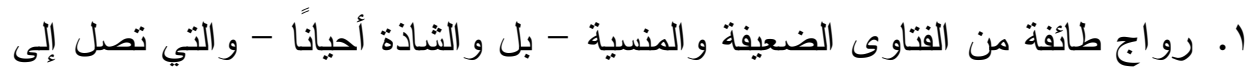

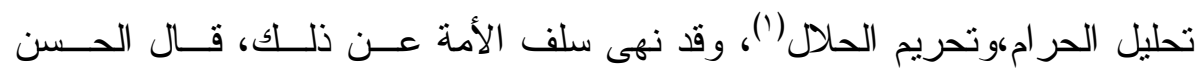
البصري- رحمه الله -:" شرار عباد الله ينتقون شرار المسائل يعمون بهـــا عبــاد الهه"(r). وقال مالك - رحمه الله --: "قال رجل للشعبي: إني خبأت للك مسائل، فقال:

\section{أخبئها لإبليس حتى تلقاه فتسأله عنها!"(").}

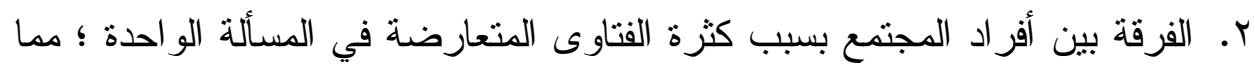

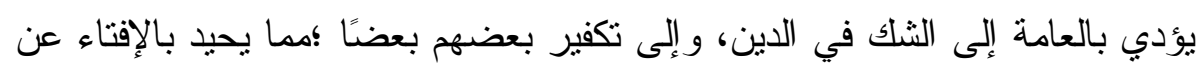

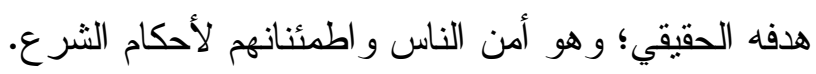

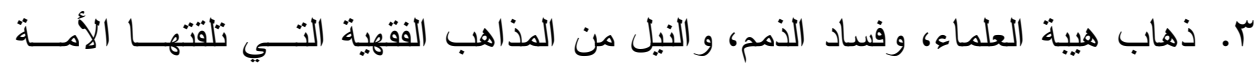

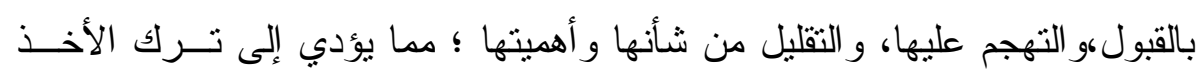

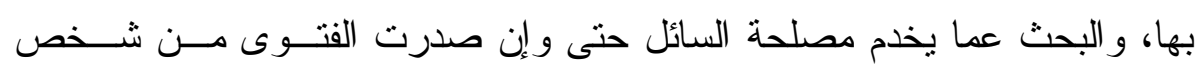
مجهول الهوية الفقهية.

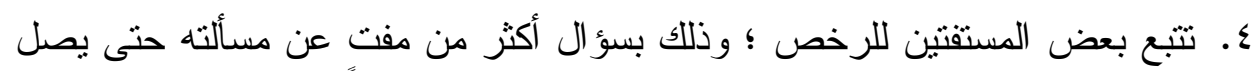

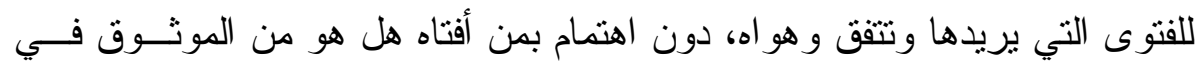

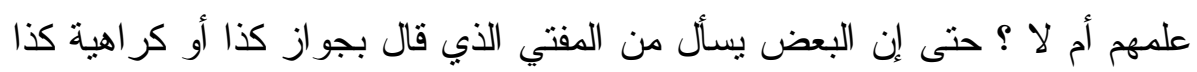

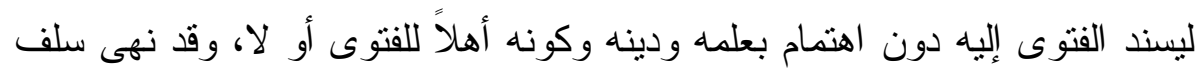

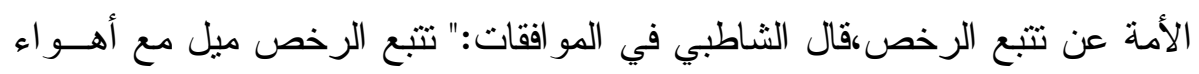

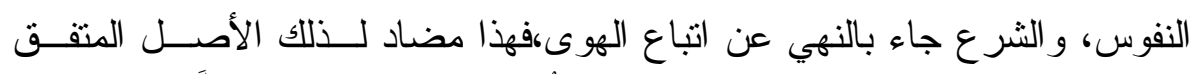

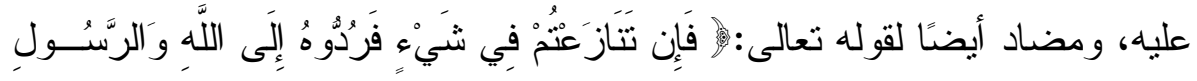

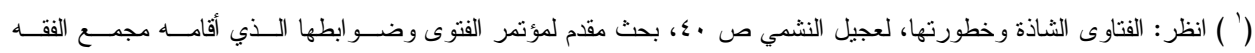




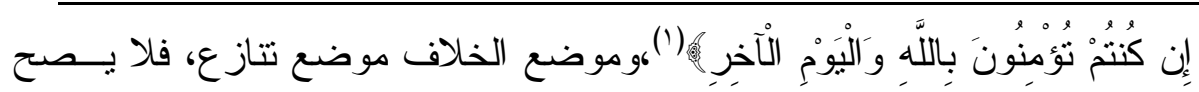

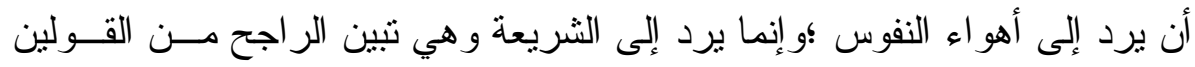

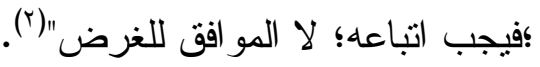

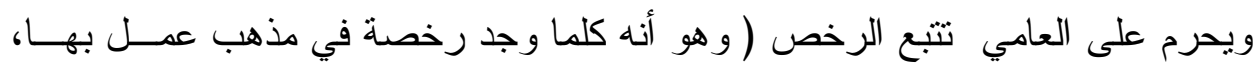

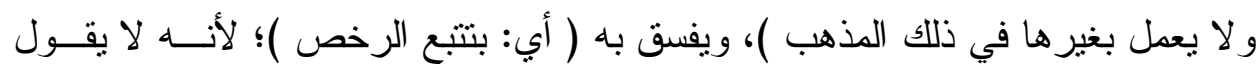

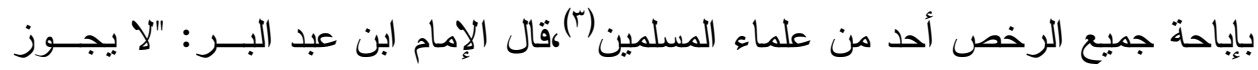

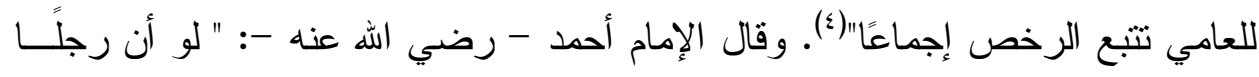

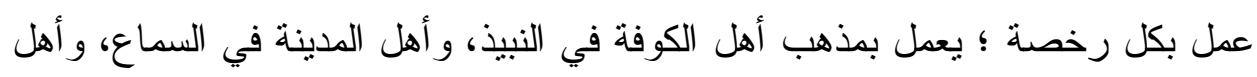
مكة في المتعة؛ لكان فاسقًا"(0).

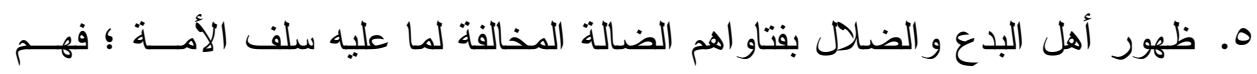
يردون النصوص التي تخالف عقائدهم بحجة مخالفتها للمعقول، ويستعملون الأقيسة

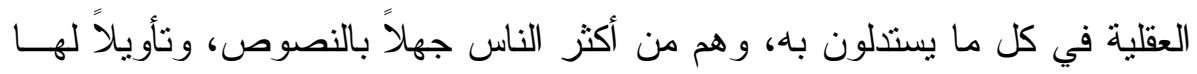

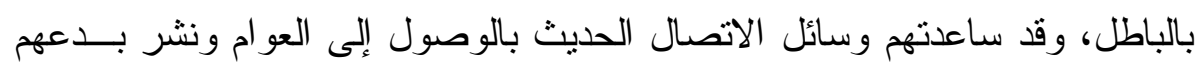

$$
\text { وفتاو اهم الضالة. }
$$

المطلب الثاني: أسباب فوضى الفتوى.

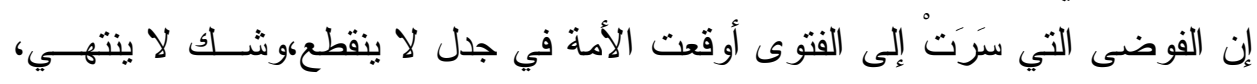

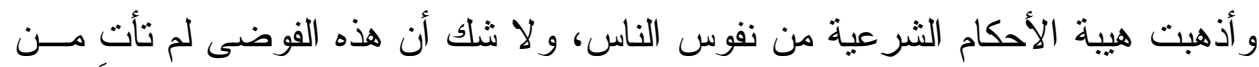

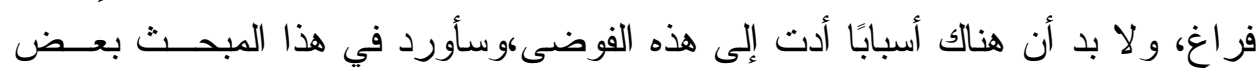

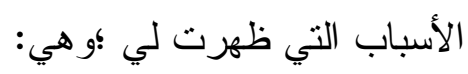

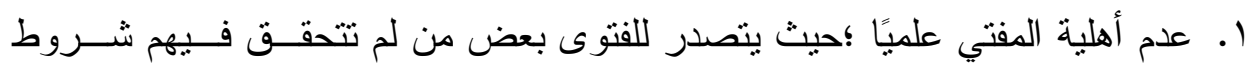

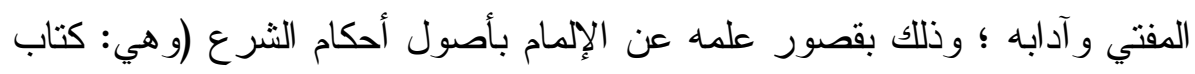

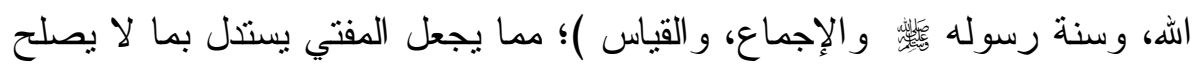

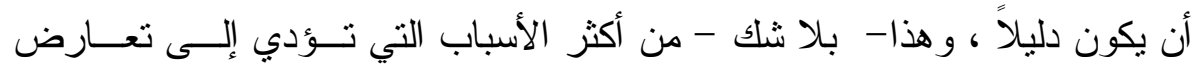

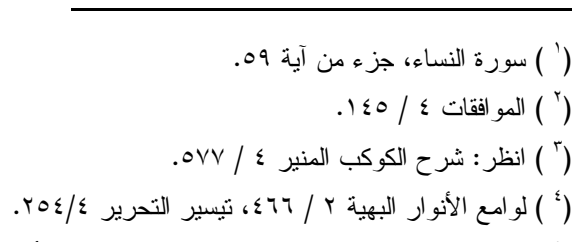

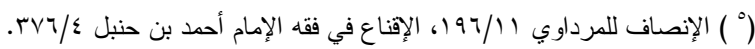


الفتوى مع غير ها. وتصدر مثل هؤلاء للفتوى ليس بالأمر الجديد،فهو أمر قد عانت

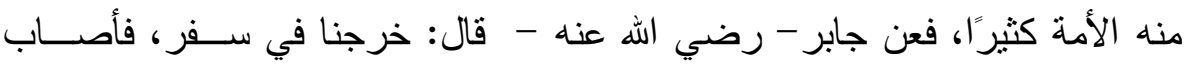

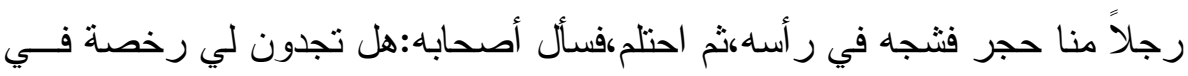

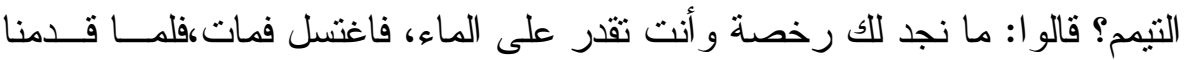
على رسول اله لهي

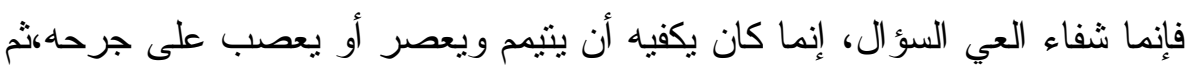

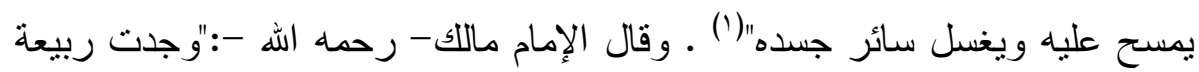

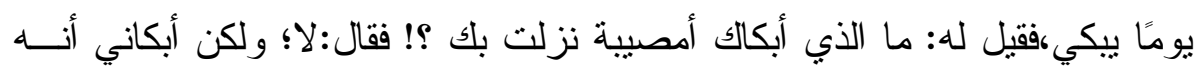

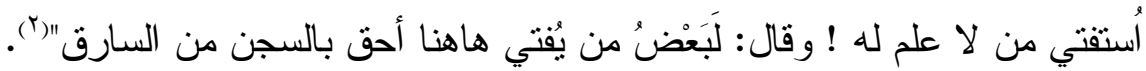

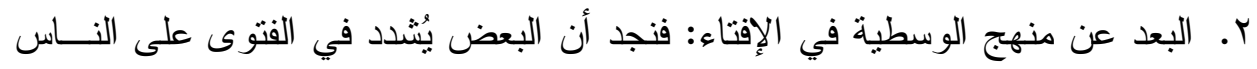

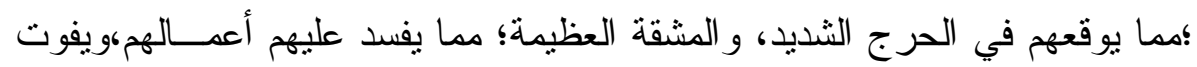

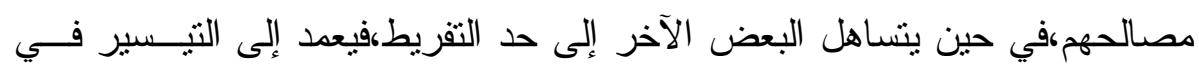

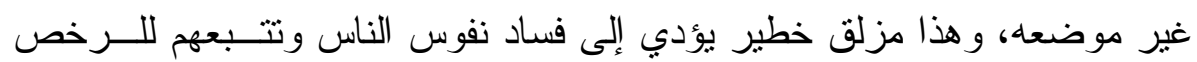
دون مسوغ شر عي، و استهانتهم بالأحكام الشر عية.

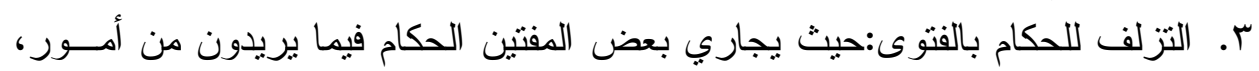

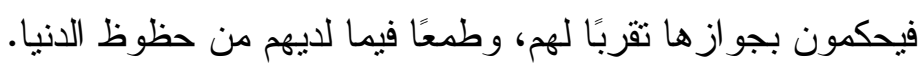

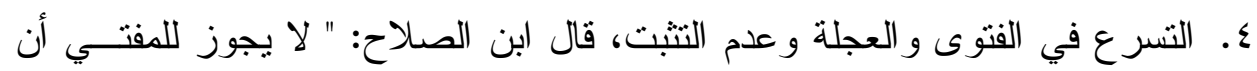

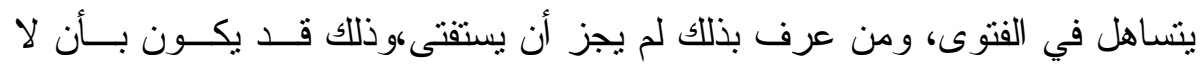

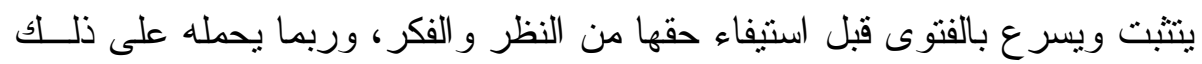

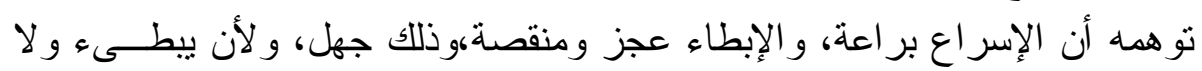

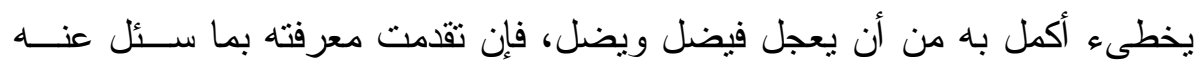

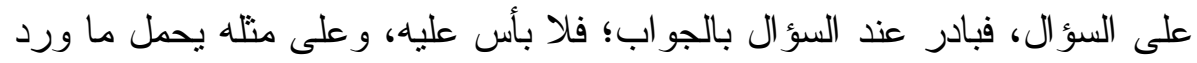

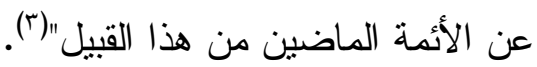

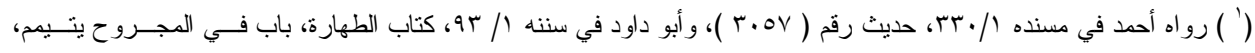

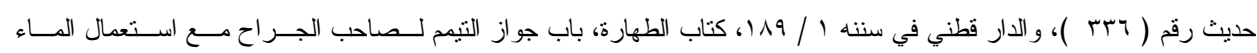

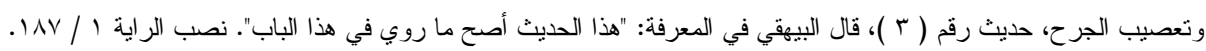

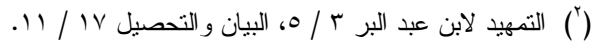

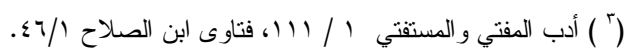


ويظهر هذا التسرع و اضحًا وجليًا في بر امج الفتاوى التي تكون مباشرة على القــــوات الفضائية،حيث يُلقي السائل سؤ اله ويجاب عنه واضه مباشرة.

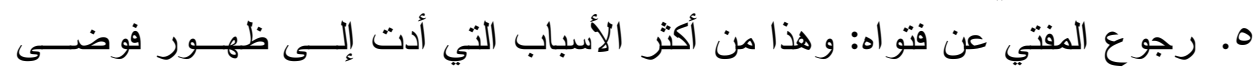
الفتوى.

7. الجهل بحال المستفتي: وحال المستفتي أمر معتبر في الفتوى قد تتغير الفتوى بسببه

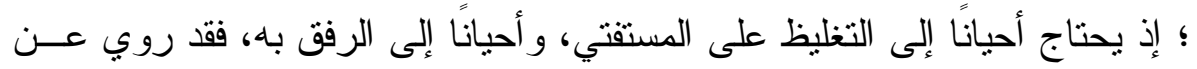

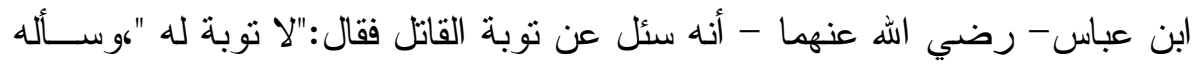

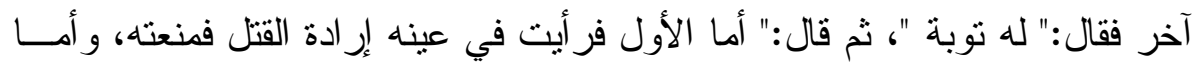

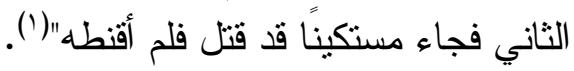

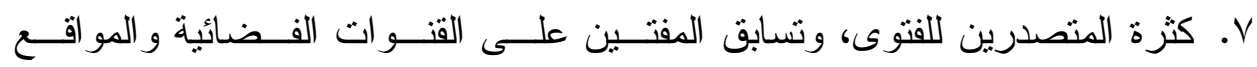

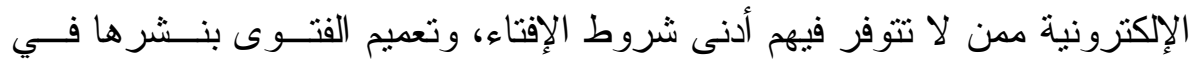

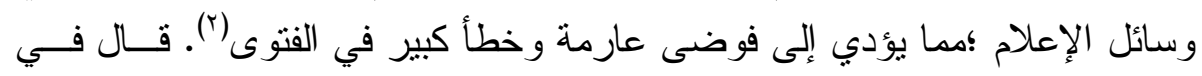

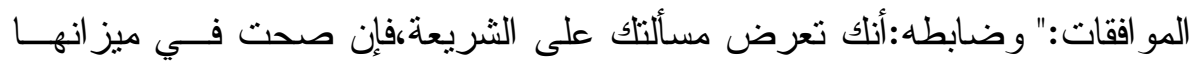

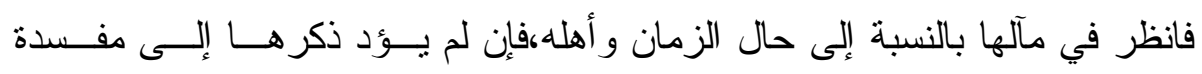

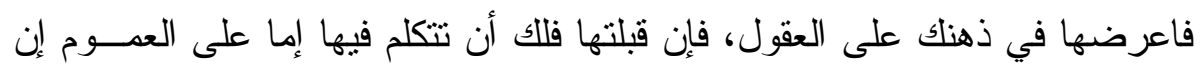

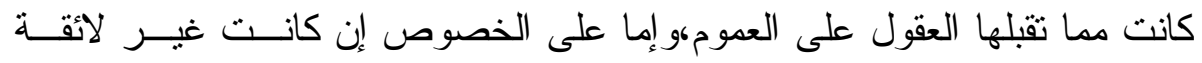

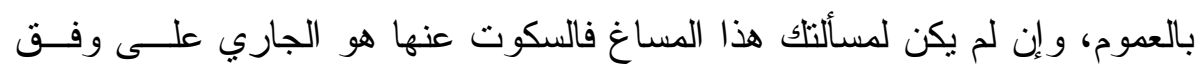

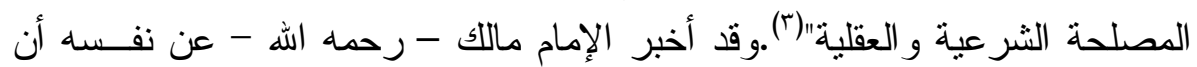

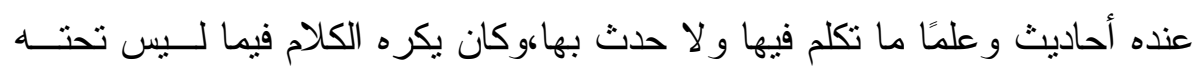

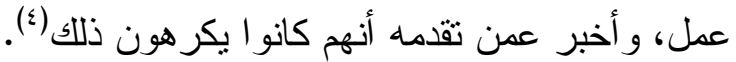

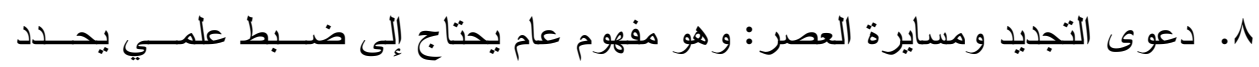
المفهوم بصورة و اضحة، وكذلك الدعوة إلى التيسير في الإسلام (ْ).

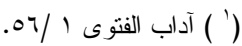

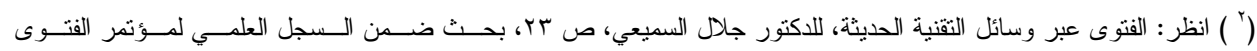
و استنشر اف المستقبل.

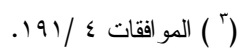

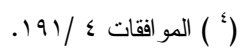

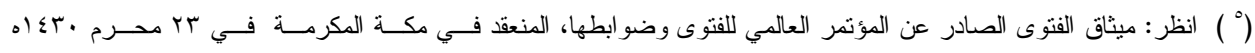


9 . . عدم خبرة المفتي في نتزيل الأحكام على الوقائع، وقلة عدد المؤهلين للفتوى الــذين تتوفر فيهم شروط المفتي و آدابه (').

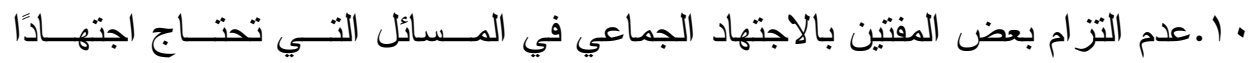

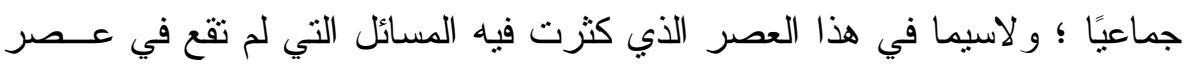

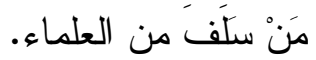

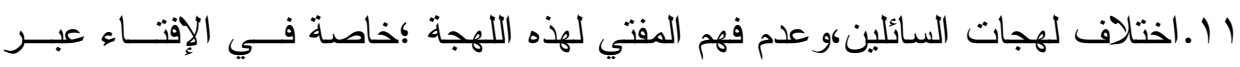
الفضائيات، فقد يفهم المفتي معنى غير مر اد السائل.

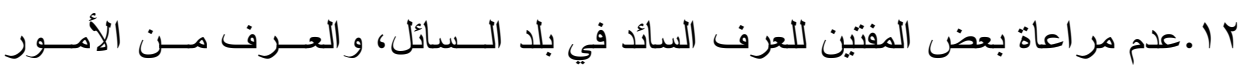

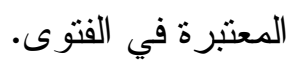
المطلب الثالث: علاج فوضى الفتوى لفوى.

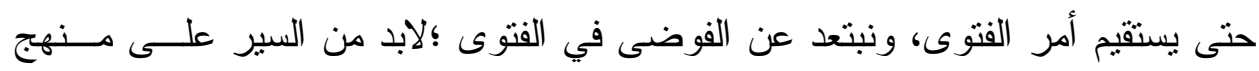

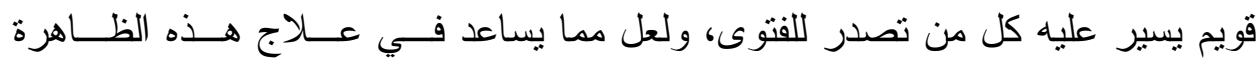

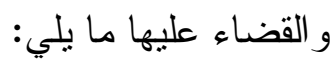

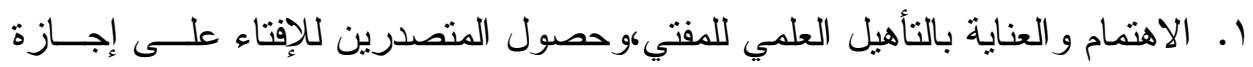

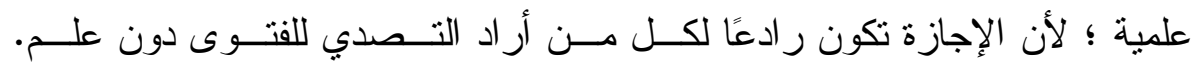

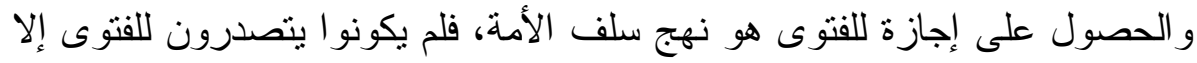

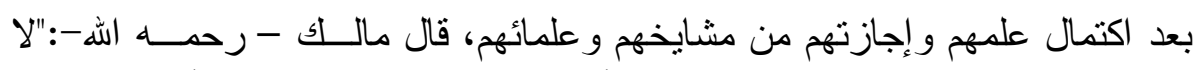

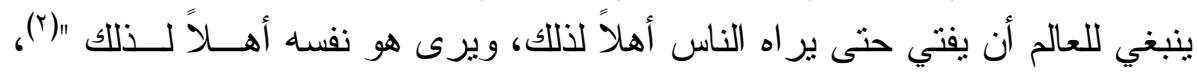

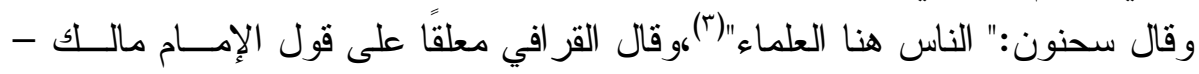

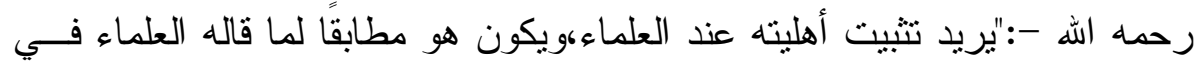

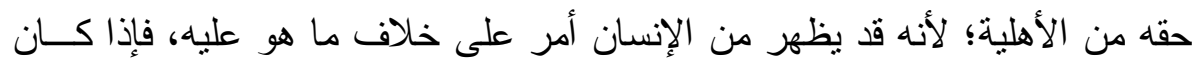

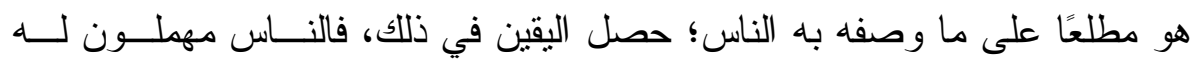

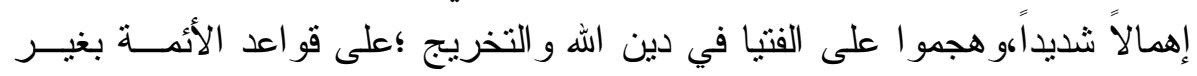

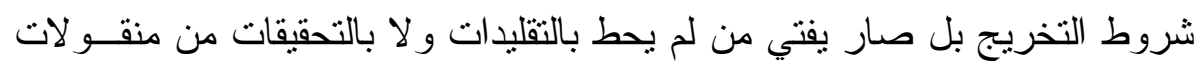

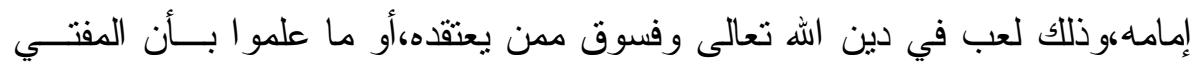


مخبر عن الله تعالى، وأن من كذب على الله تعالى،أو أخبر عنه مع عدم ضبط ذللك

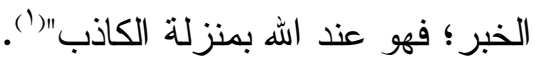

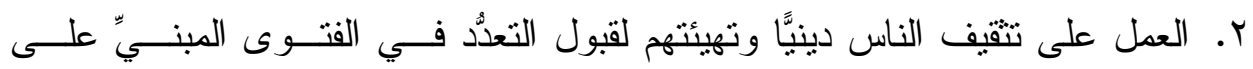

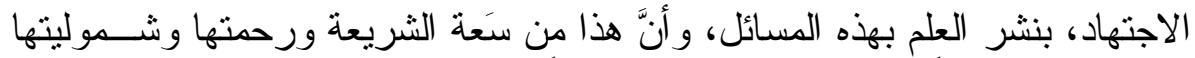

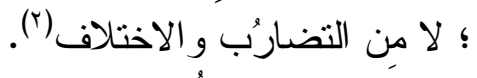

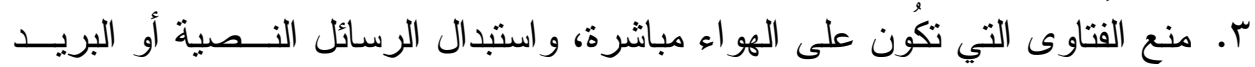

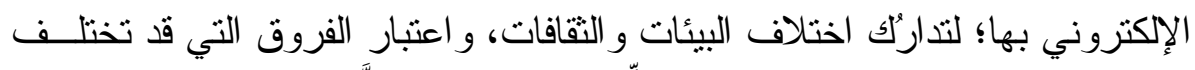

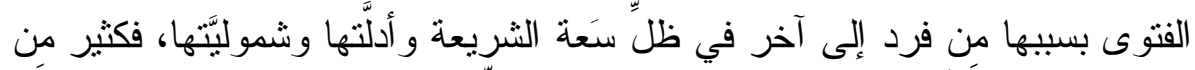

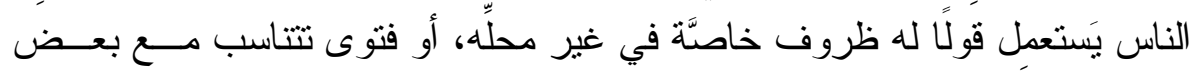

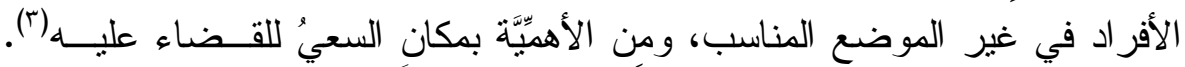

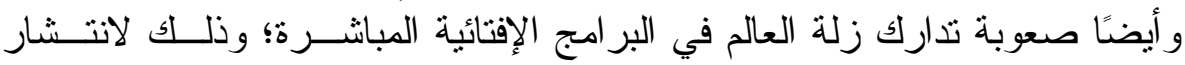

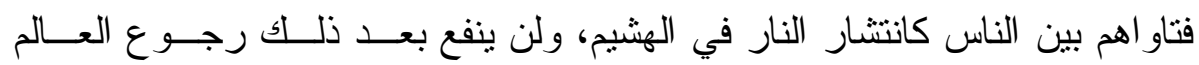
عنهاءأو رد العلماء عليها (أ).

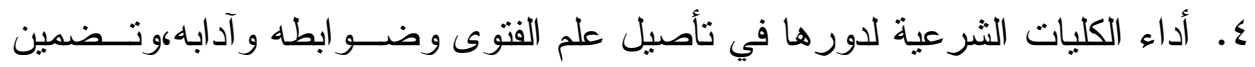

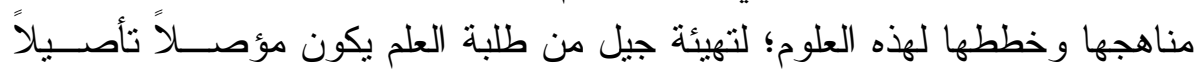

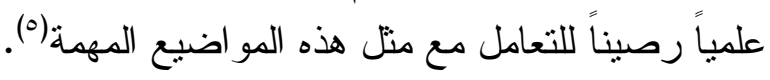

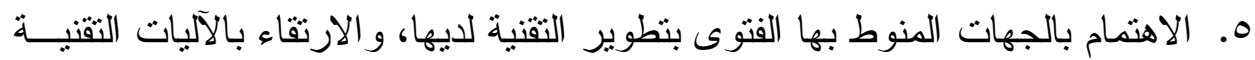

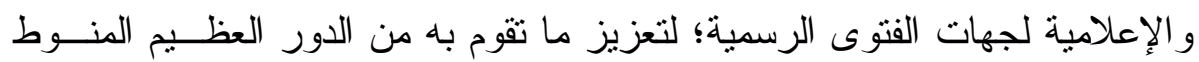

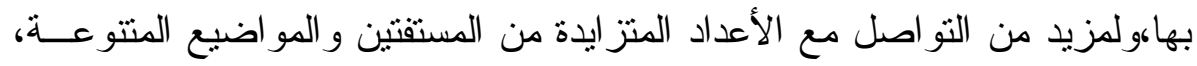

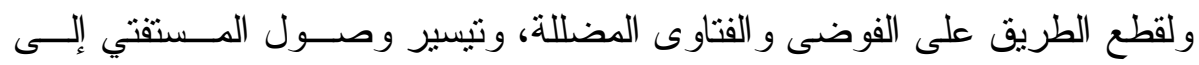
المو اقع الرسمية، وتقريغ طلبة العلم لهذه المو اقع (؟).

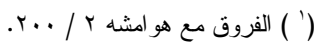

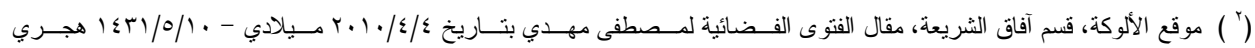
.ht t ps://umw.al ukah.net /shari a

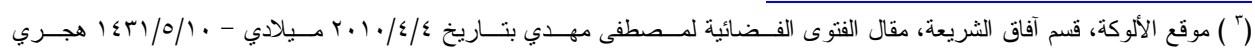
.ht t ps://www.al ukah.net /shari a

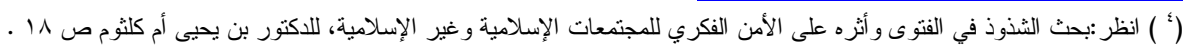

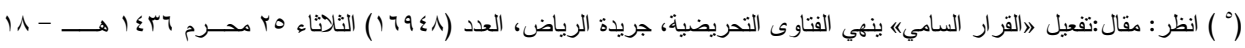


المبحث الثالث: سلطة الحاكم في تقييد الفتوى وأثرها في الأمن الفقهي

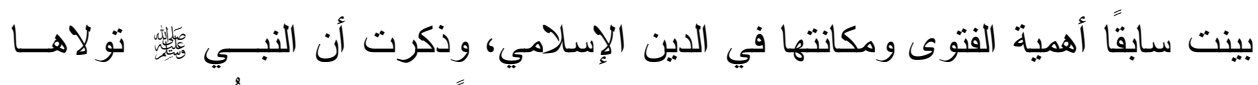

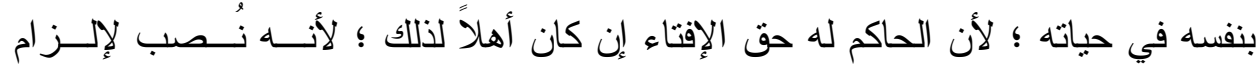

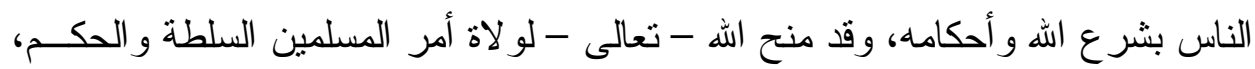

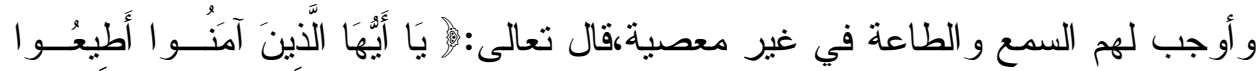

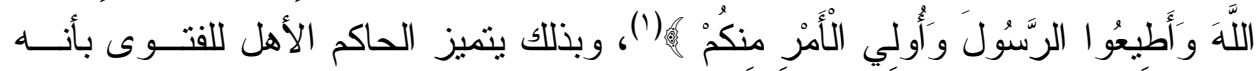

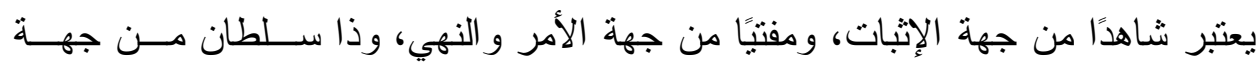

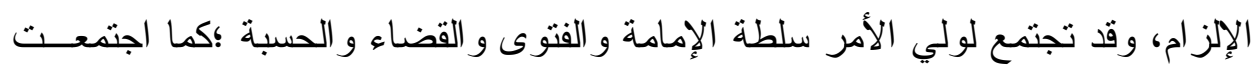

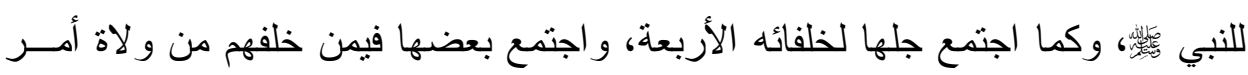

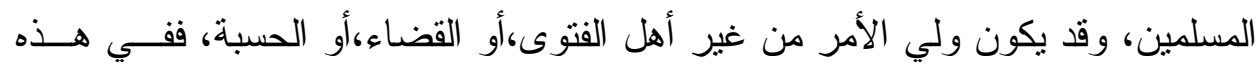

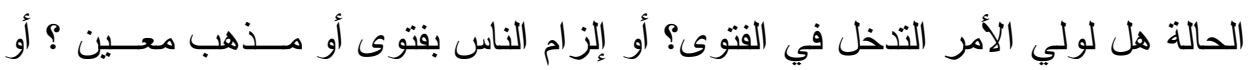
تقييد الفتوى بجهة معينة أو مفتٍ معين ؟ وما أثر ذلك على فلى الأمن الفقهي ؟

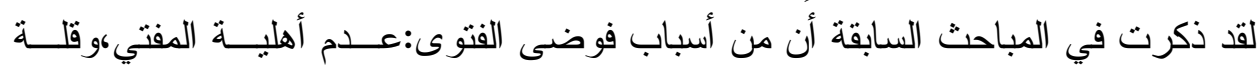

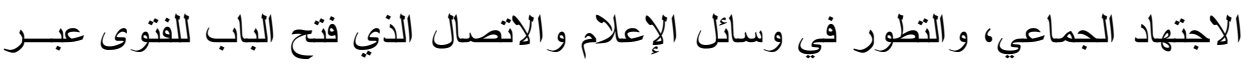

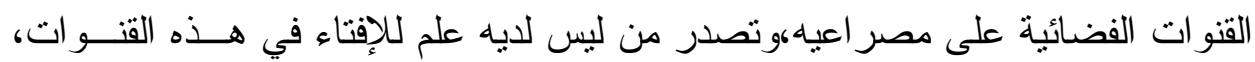
وذكرت أيضًا أن من مظاهر هذه الفوضى:ظهور فتاوى أهل البدع و الضاله، وتـسـاهل

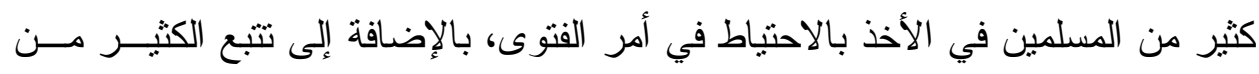

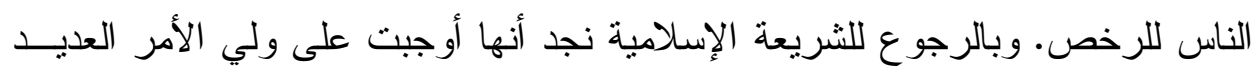

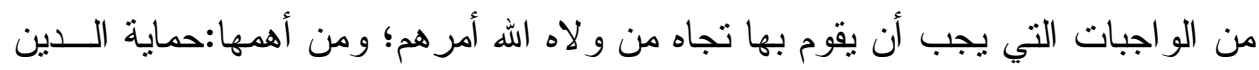

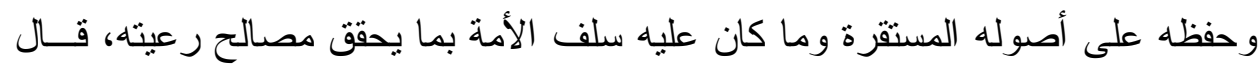
ئس

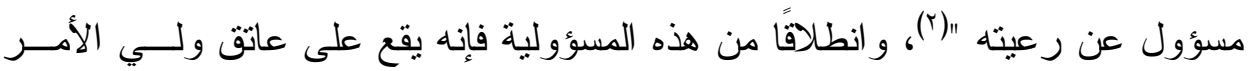

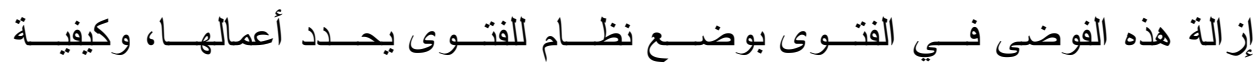

(' (' سورة النساء، جزء من آية 09.

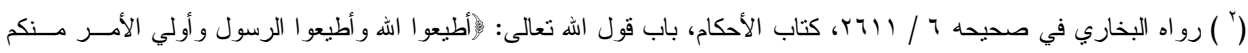

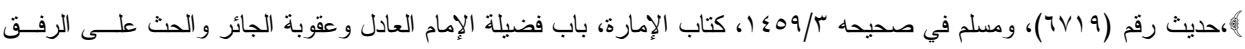

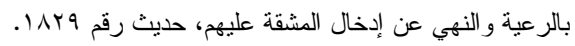




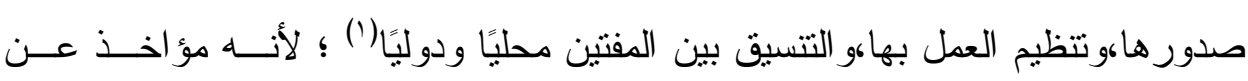

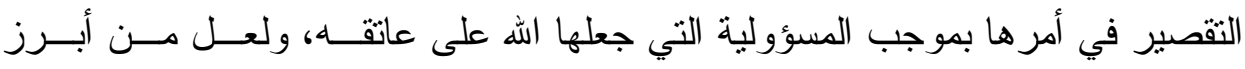

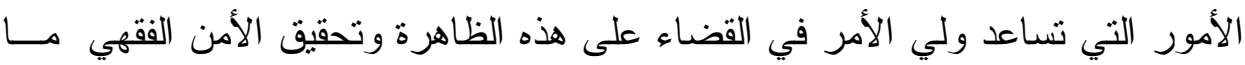

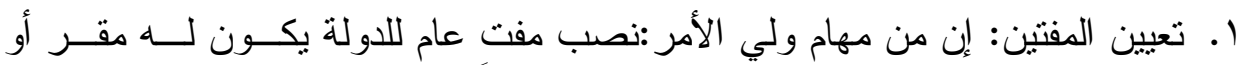

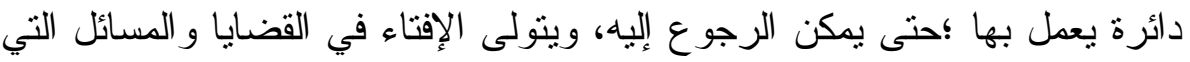

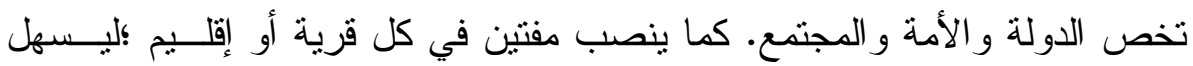

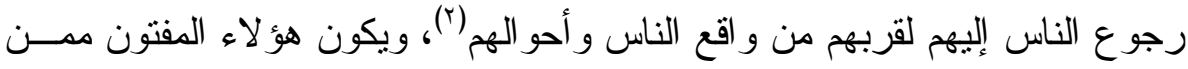

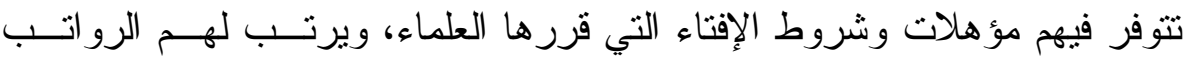

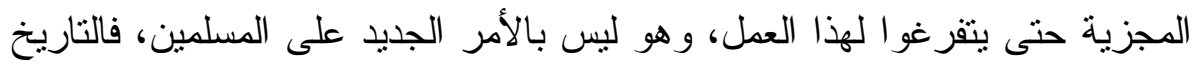

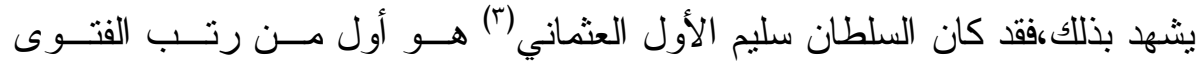

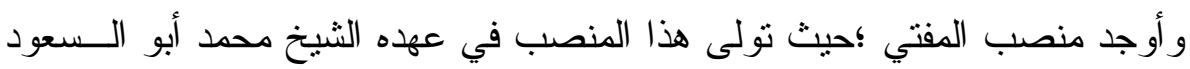

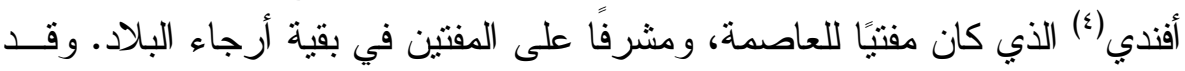

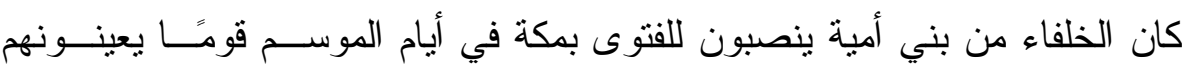

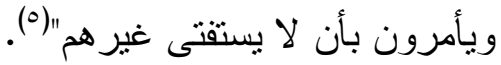

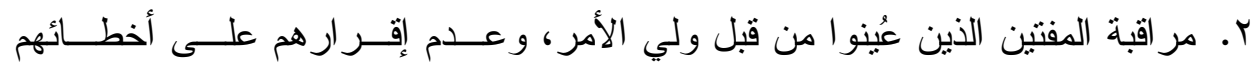

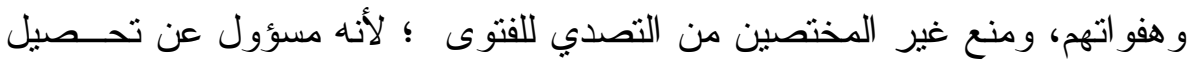

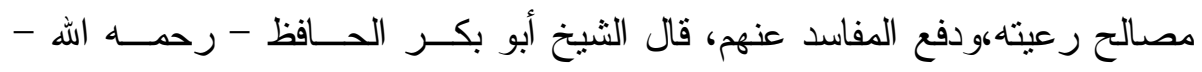

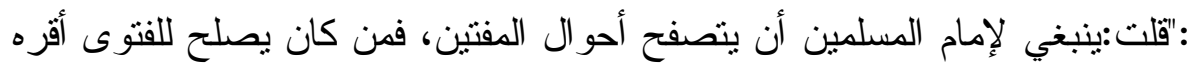

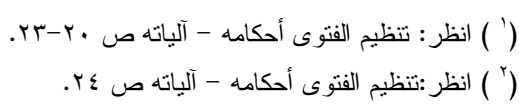

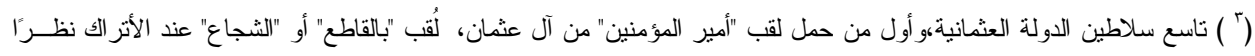

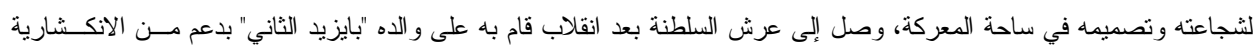

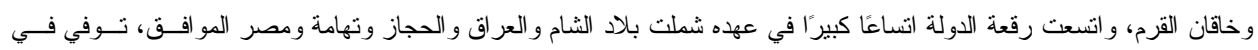

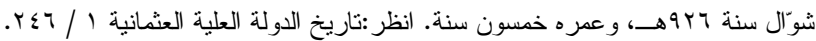

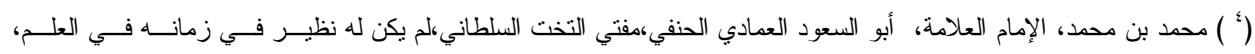

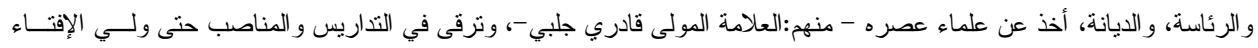

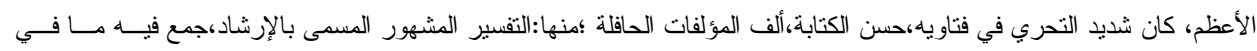

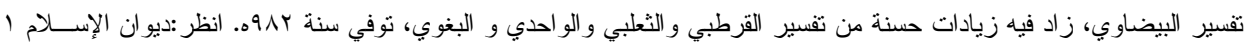


عليها، ومن لم يكن من أهلها منعه منها، وتقدم إليه بأن لا يتعرض لهــا، وأوعـــهـ

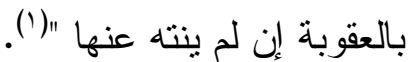

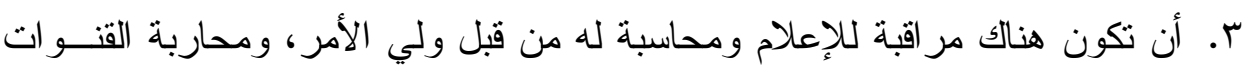

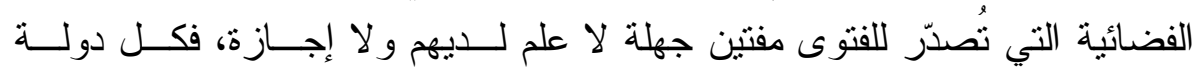

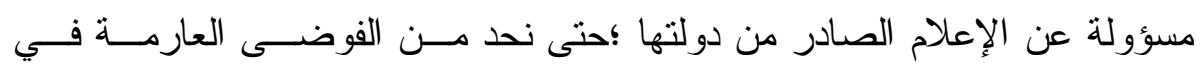

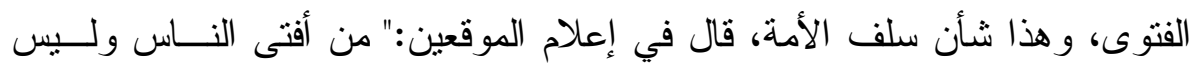

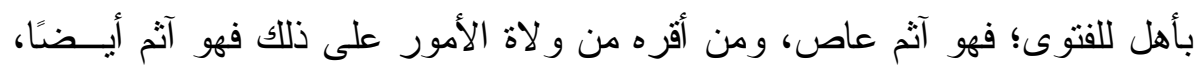

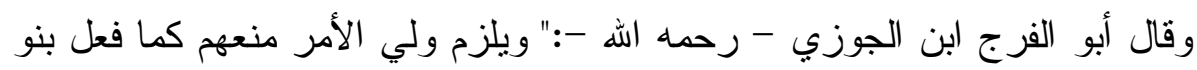

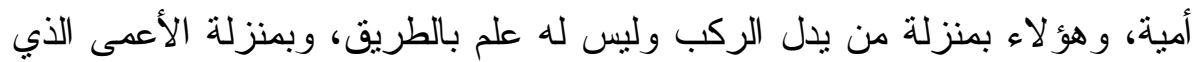

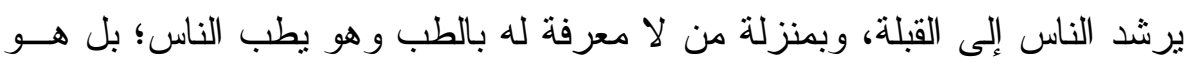

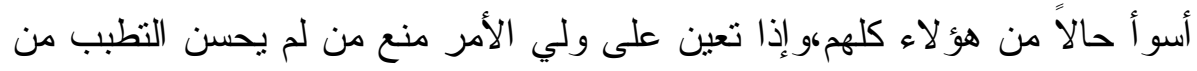

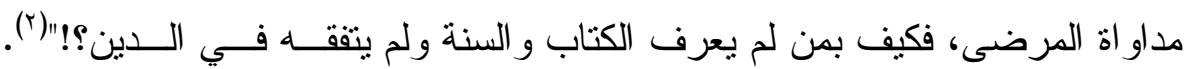

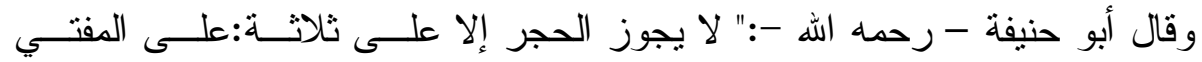

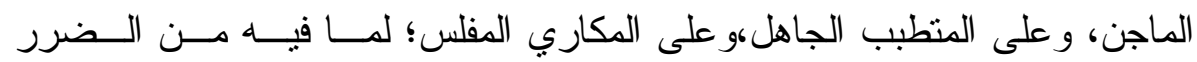

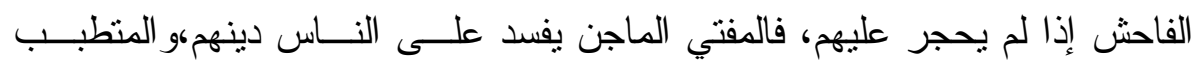

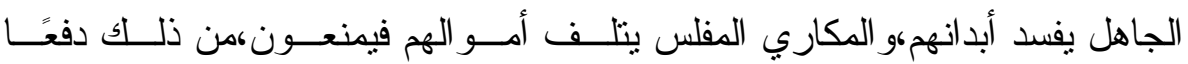

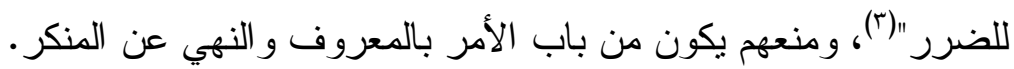

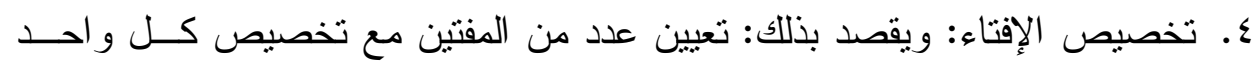

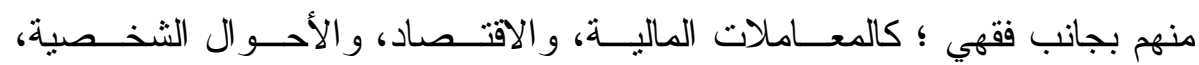

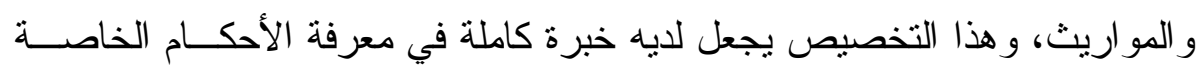

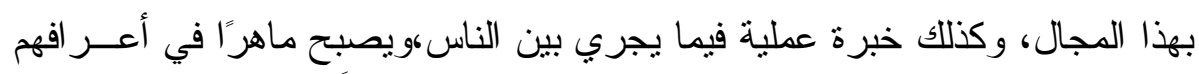

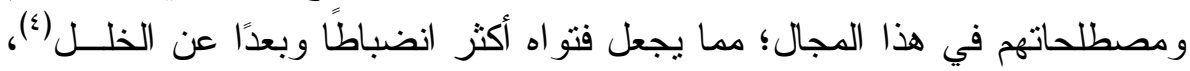

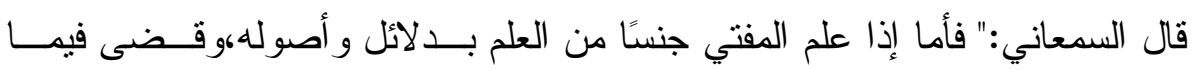
سو اه - كعلم الفر ائض وعلم المناسك - ؛لم يجز أن يفتي في غيره"(ه).

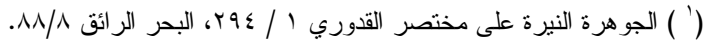

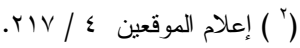

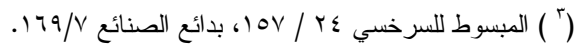

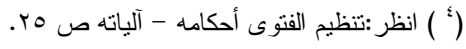

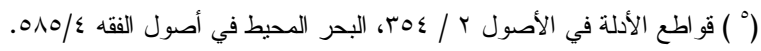




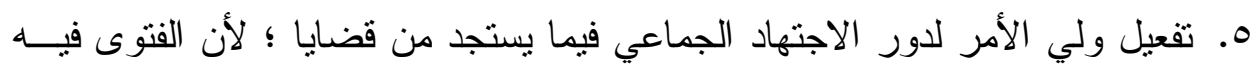

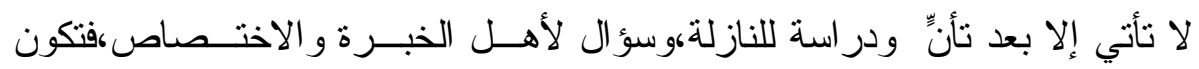

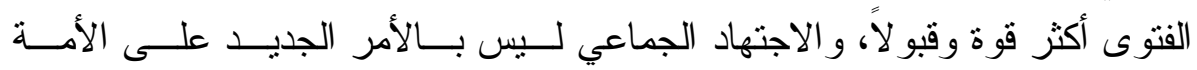

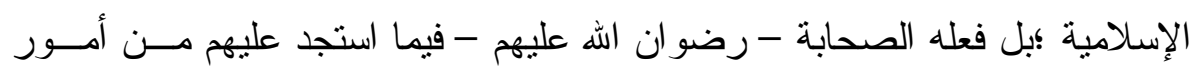

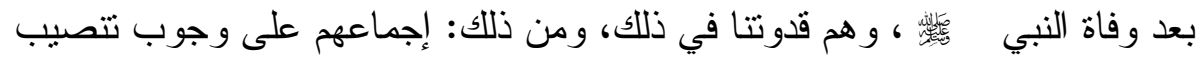

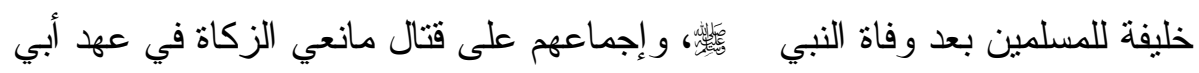

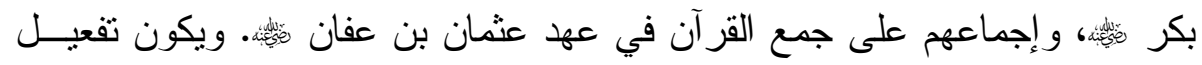

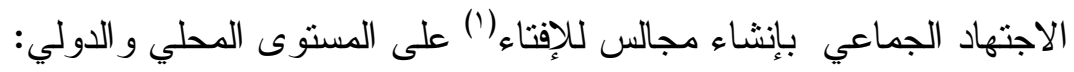

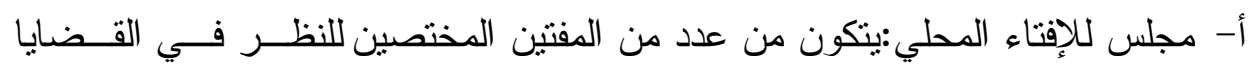

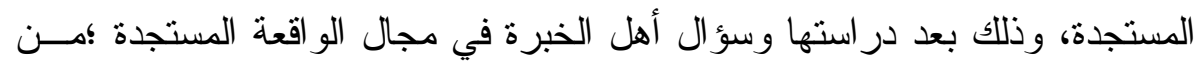

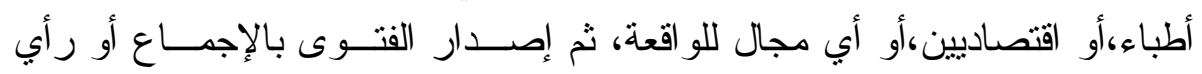

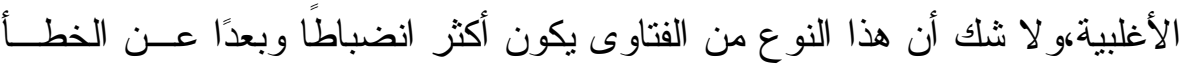

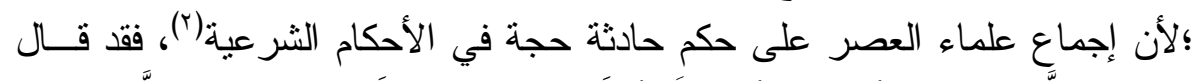

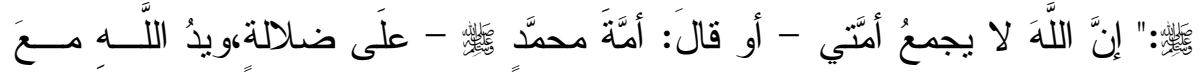

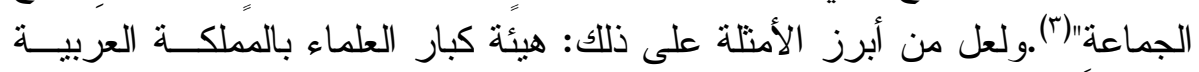

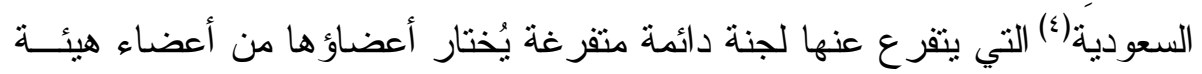

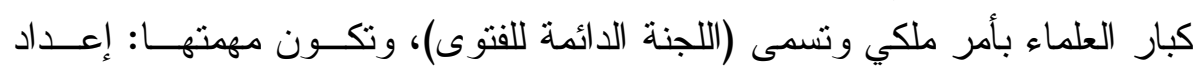

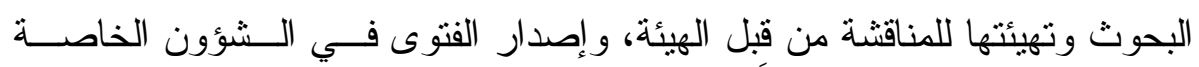

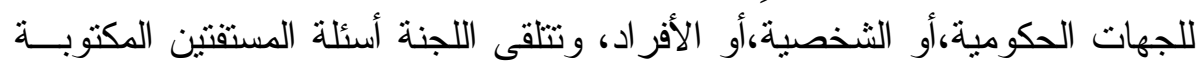

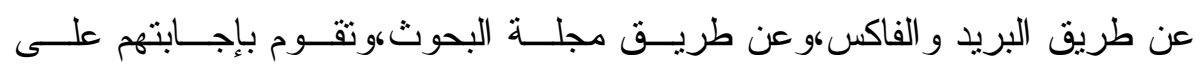

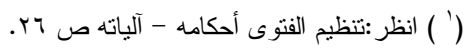

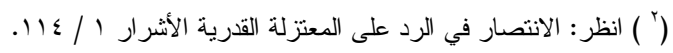

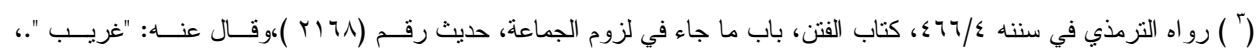

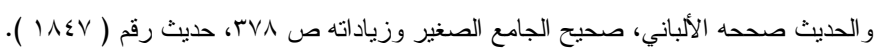

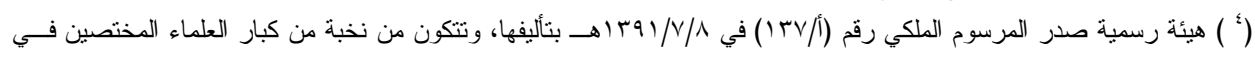

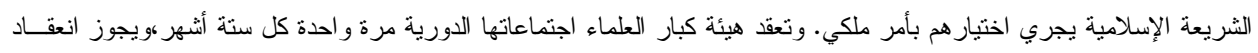

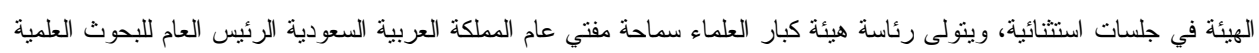

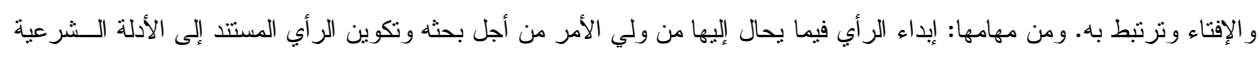

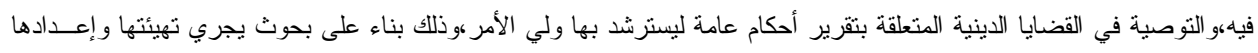
بهذا الخصوص. الموقع الرسمي لهيئة كبار العلماء ht t p://www.ssa.gov.sa. 
عناوينهم، أما بالنسبة للأسئلة الثفهية فيتم الاتصال بأعضاء اللجنة مباشرة(' هوقـــ

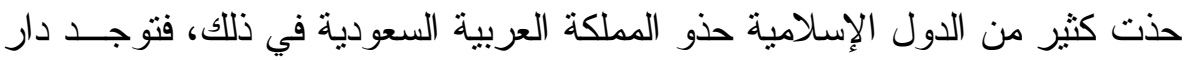
للإفتاء في مصر و الأردن ودول الخليج وماليزيا وغير ها من الدول الإسلامية.

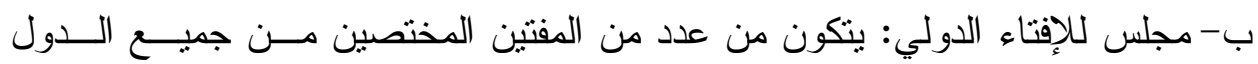

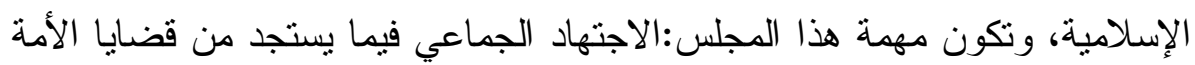

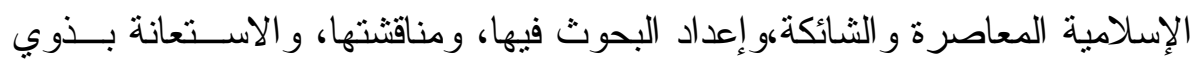

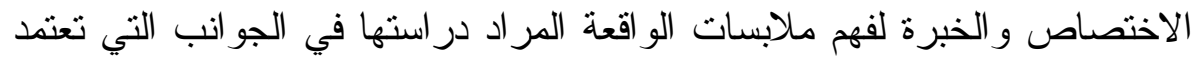

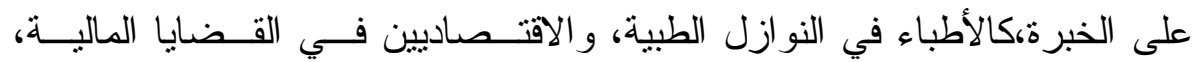

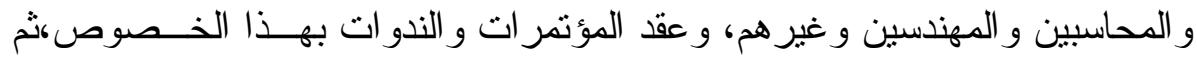

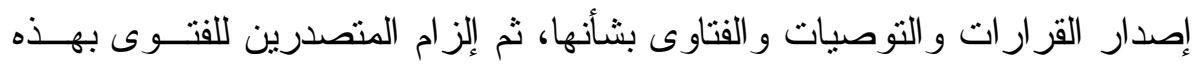

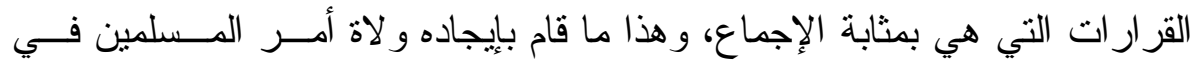

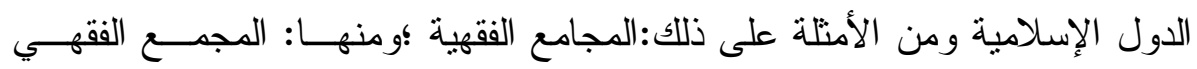
التابع لر ابطة العالم الإسلامي ومقره في المملكة العربية السعودية، ومجمع البحوث الإنه

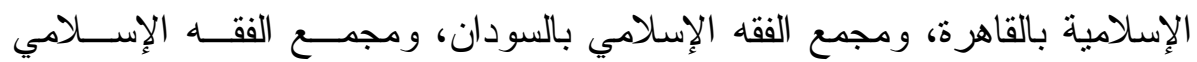

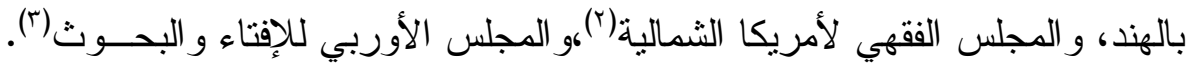

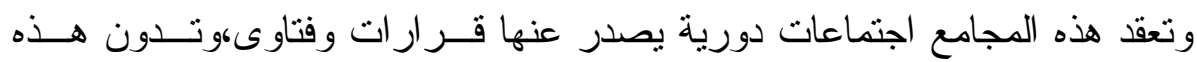

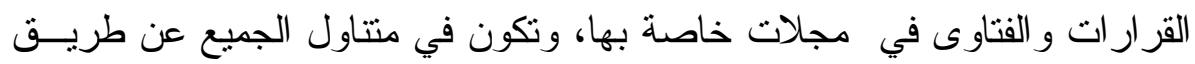
نسخ إلكترونية من هذه المجلات على مو اقعهم الإلكترونية.

(') الموقع الرسمي لهيئة كبار العلماء ('ht t p://www.ssa.gov.sa.

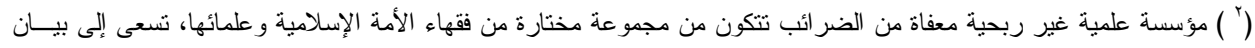

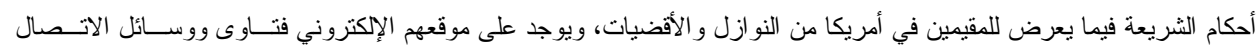

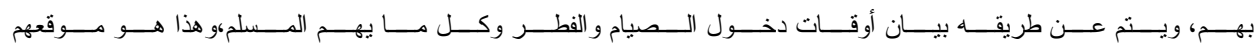

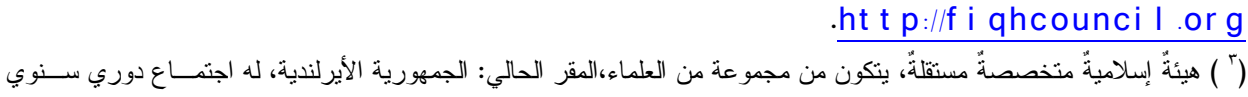

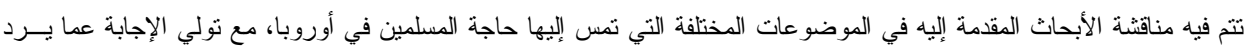

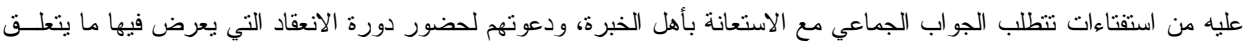

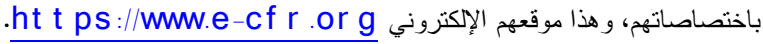


المبحث الر ابع: أثر فوضى الفتوى على البعـــ الــديني، والاجتمــاعي، والــي ويشتمل على ثلاثة مطالب:

المطلب الأول: أثر فوضى الثله مطاب: الفتوى على البعد الديني.

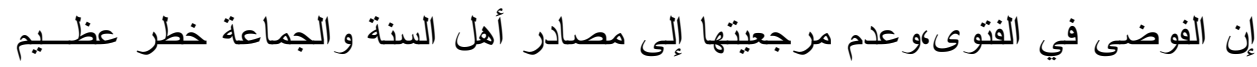

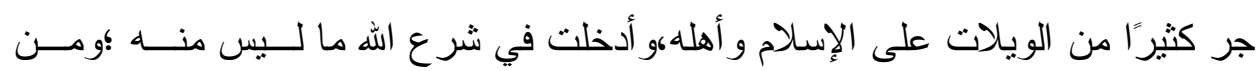

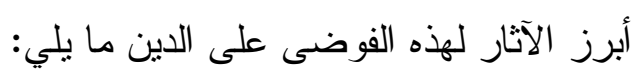

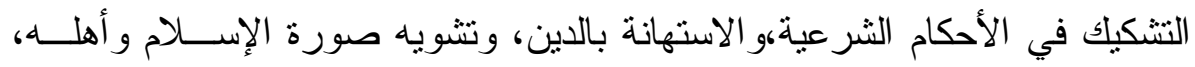

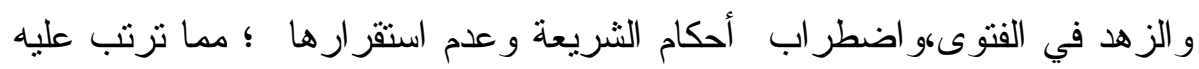

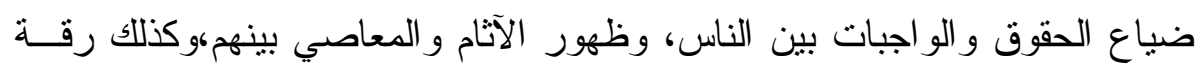
الدين،واستمر اء الحر ام (').

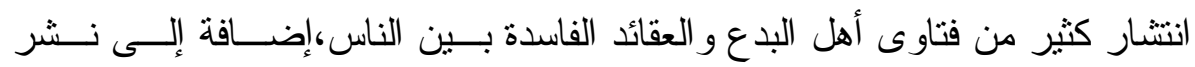

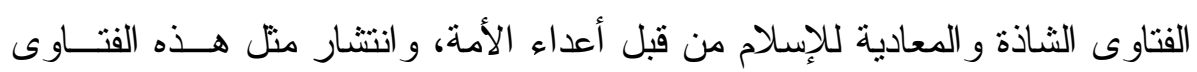
يلبِّسُ على المسلمين دينهم، وينفر غير هم من الاخول فيه.

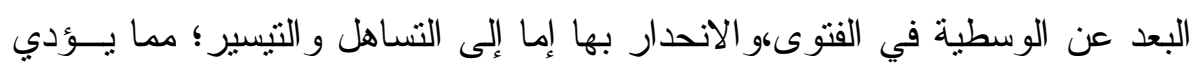

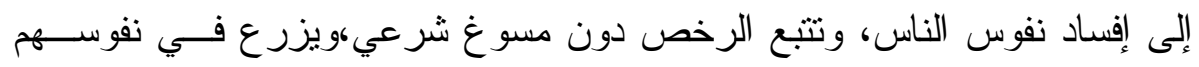

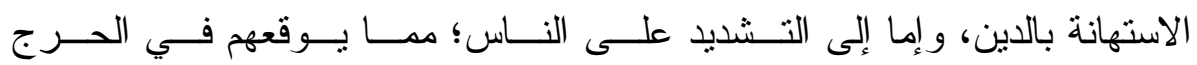

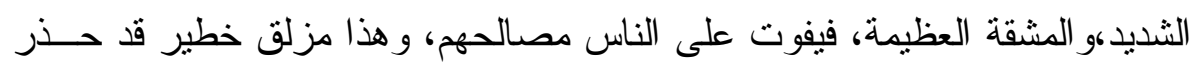

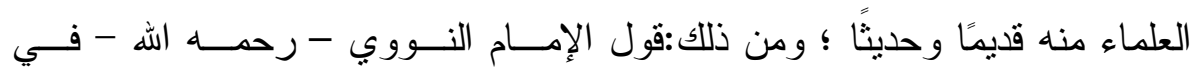

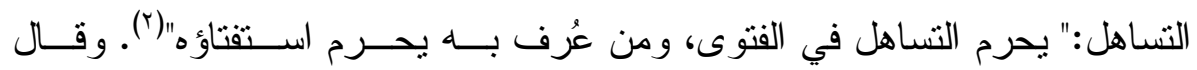

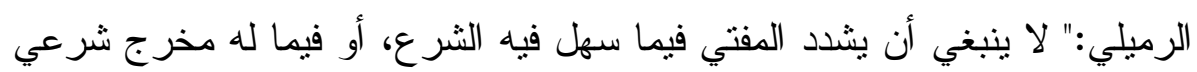

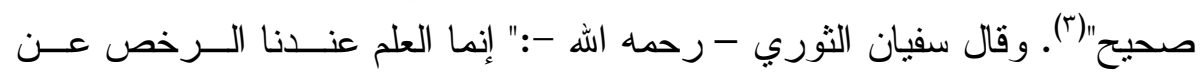

النقات، أما التشديد فكل إنسان بحسنه"(؛). 
زعزعة التقة بين العلماء و العامة بتشويه صورة العلماء، و انتقــادهم،و الطعن فــيهم وفي فتاو اهم، وسبهم، و الحكم على نياتهم، وتتفير الناس منهم، وعدم الأخذ بأقو الهم

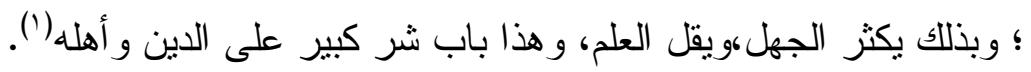

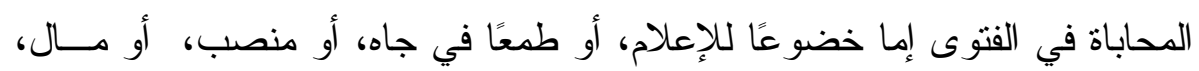

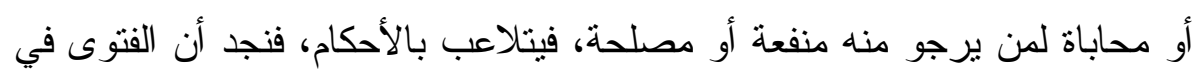

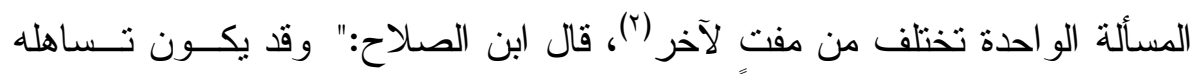

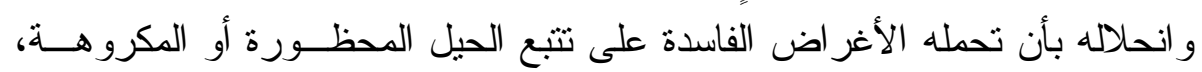

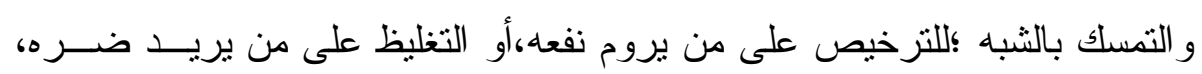

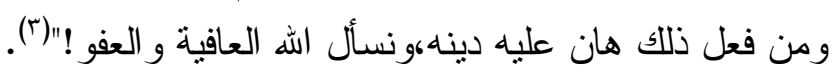
المطلب الثاني: أثر فوضى الفتوى على البعد الاجتماعي.

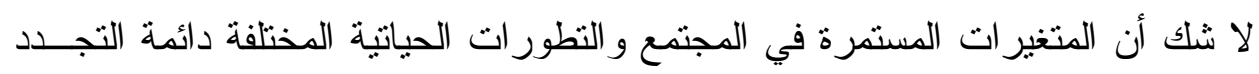

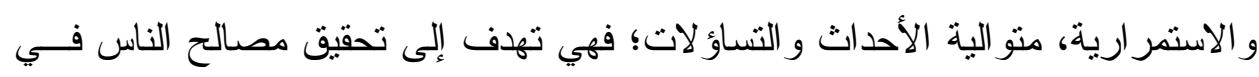

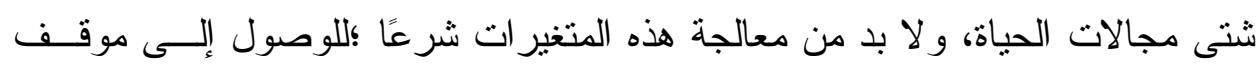

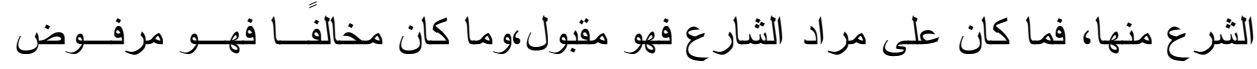

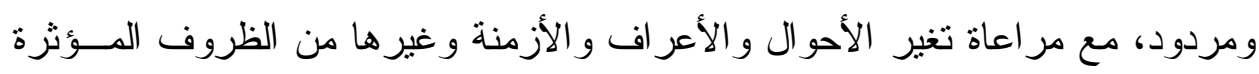

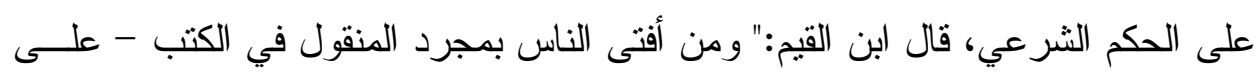

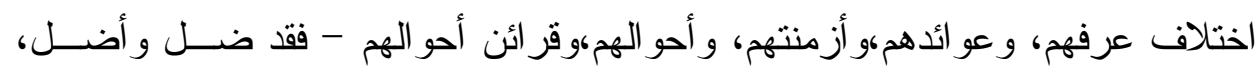

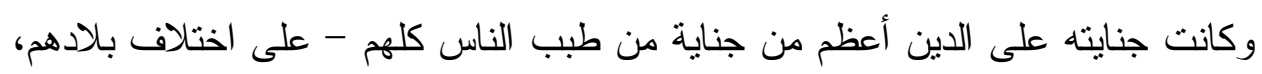

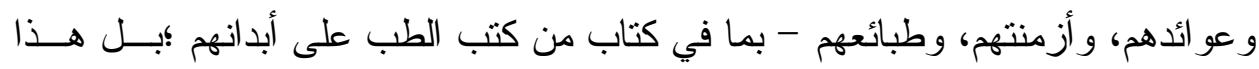

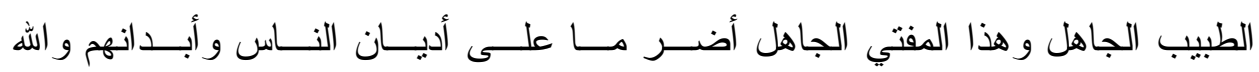

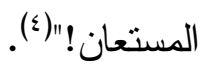

ولعل من أبرز القضايا الاجتماعية التي شهدت فوضى عارمة في الفتوى:

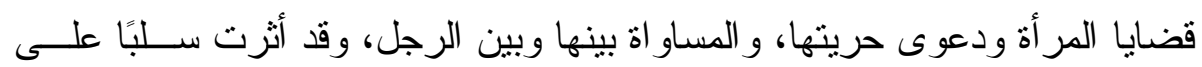

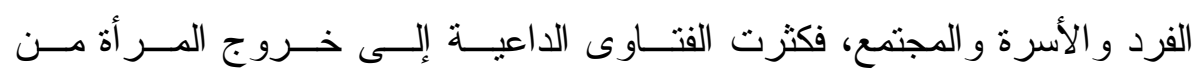




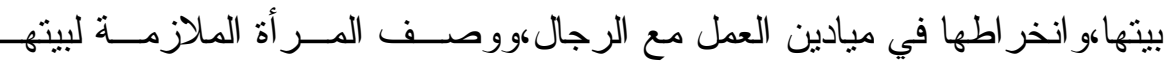

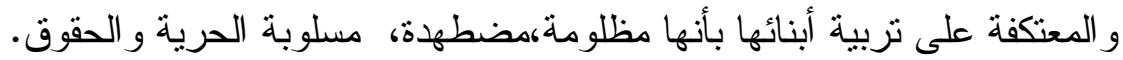

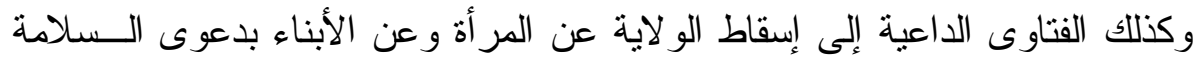

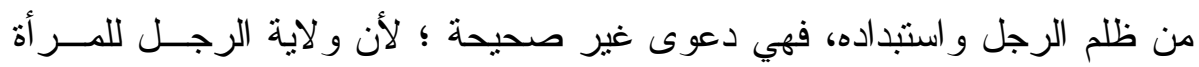

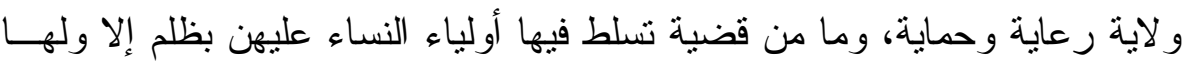

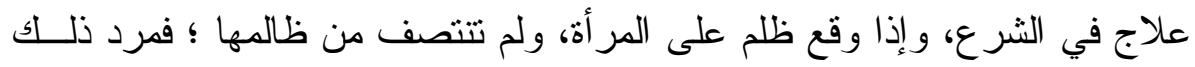

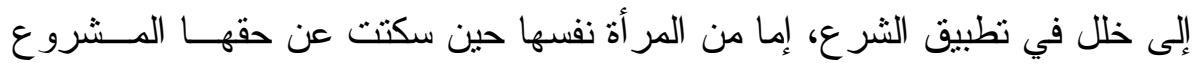

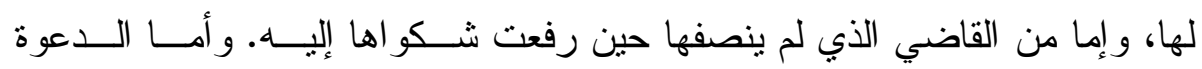
لإسقاط و لاية الرجل على المرأة بسبب ظلم بعض الأولياء؛ فهي دعوة لتعميم الظلم

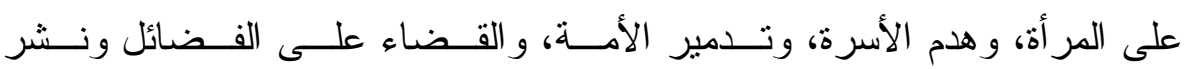

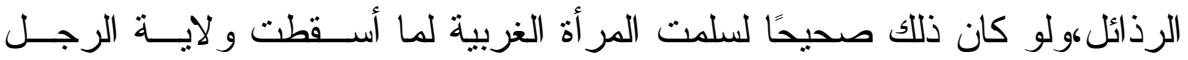

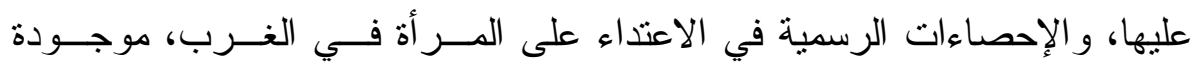

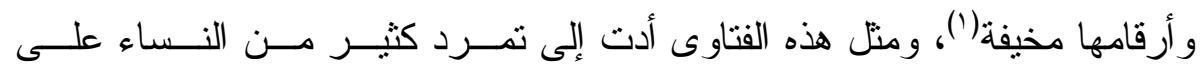

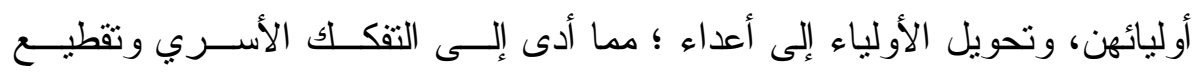
الأرحام في بعض المجتمعات.

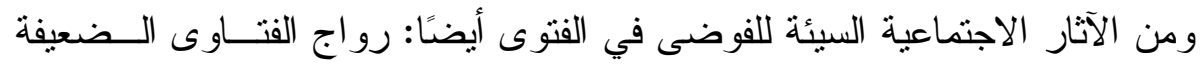

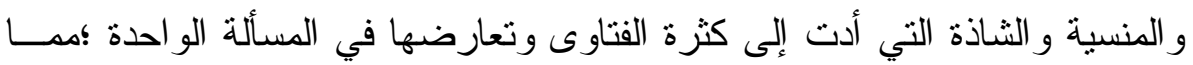

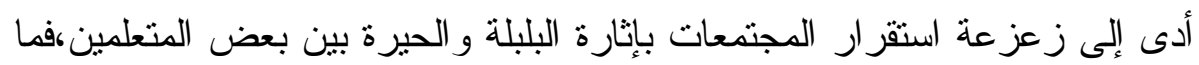

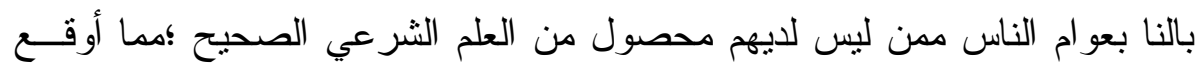

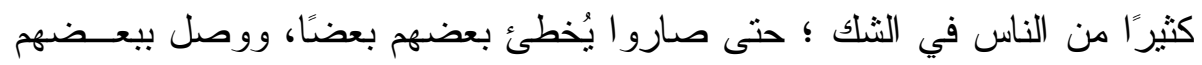

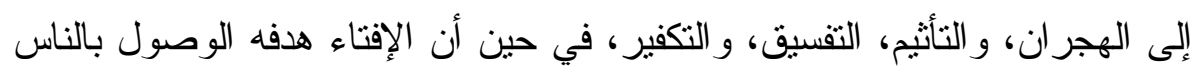

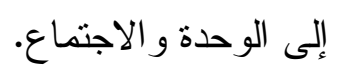

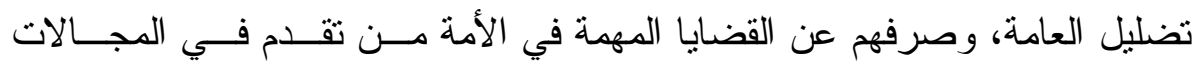

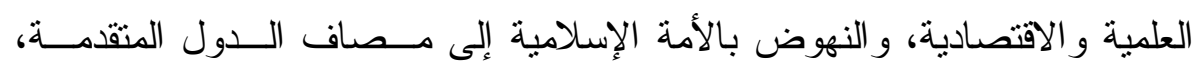

$$
\text { و الوقوف في وجه أعدائها. }
$$


تدمير اقتصاد الدول الإسلامية فبدلاً من استثمار الدول لثرو اتها في مجالات التقــدم

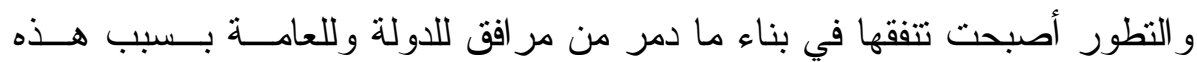
الفتاوى المضللة. المطلب الثالث: أثر فوضى الفتوى على البعد السياسي.

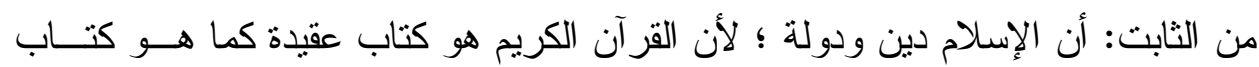

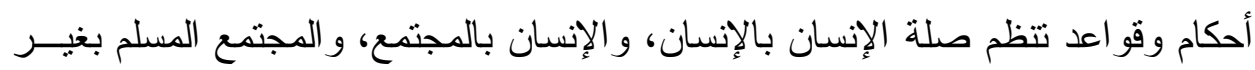

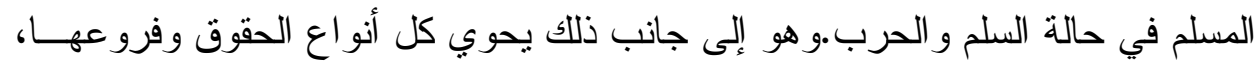

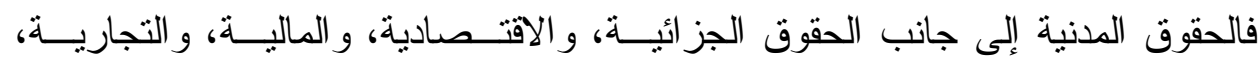
و الدولية بفر عيها العامة و الخاصة.ولم تكن هذه الحقوق مو اعظ متروكة لرغبة الإنـسـان

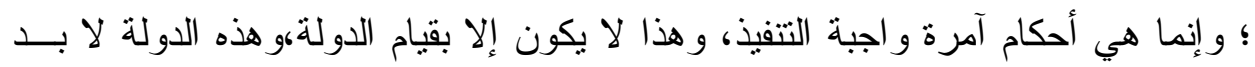

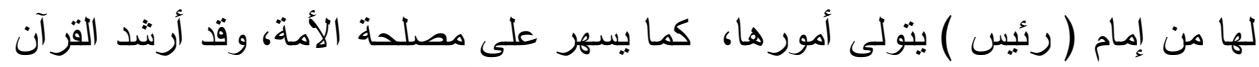

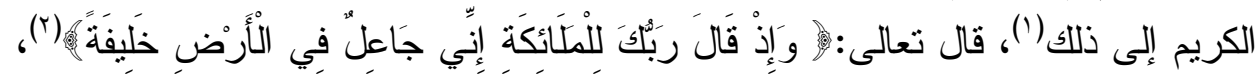
وقد أدت الفوضى في الفتوى إلى :

التوظيف السياسي للفتوى (أو ما يسمى تسييس الفتوى )لإضفاء الــشرعية الدينيـــة

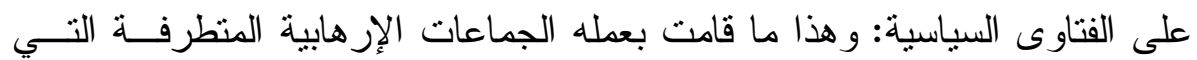

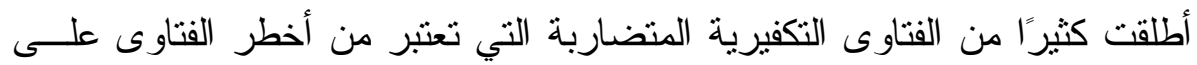
الأمة الإسلامية، فقد أدت إلى الخروج على الحكام،وظهور أعمال العنف، و إهــدار

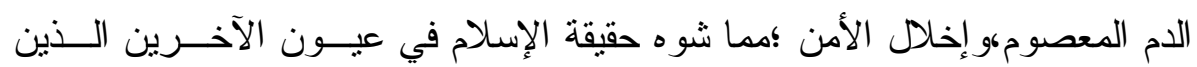

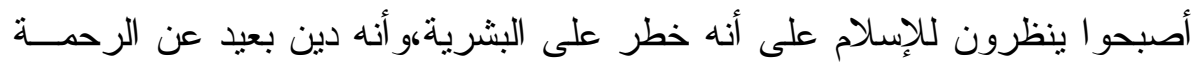

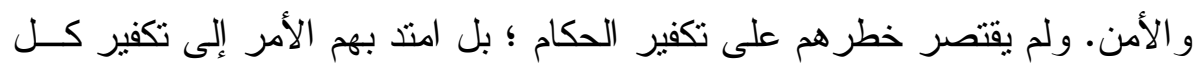

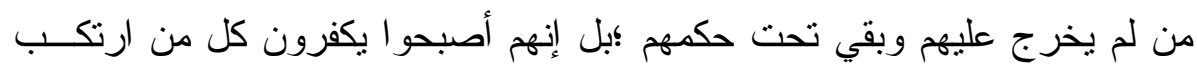

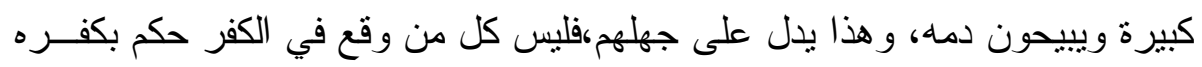

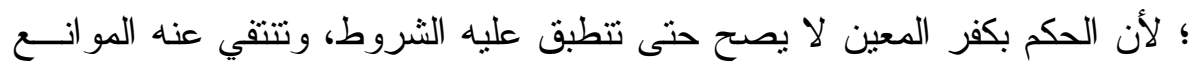

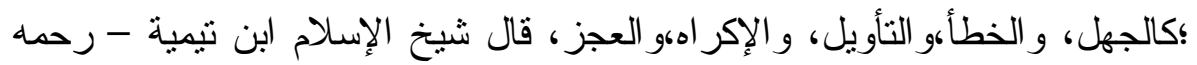

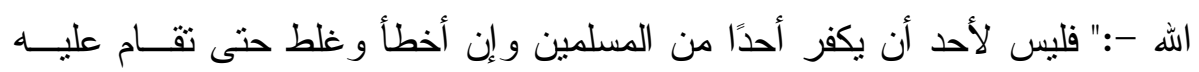




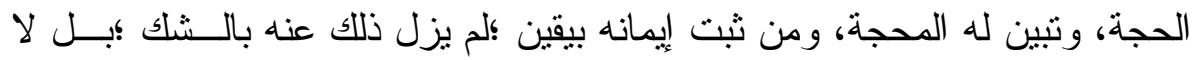
يزول إلا بعد إقامة الحجة، وإز الة الثبهة" (1). ترويع الآمنين: فهذه الفتاوى أصبحت تشكل خطرًا عظيمًا على الاستقر ار و التعايش السلمي بين الثعوب، وتحقيق الأمن الإنساني، فهذه الفتاوى أدت إلى تلى تكوين مفاهيم

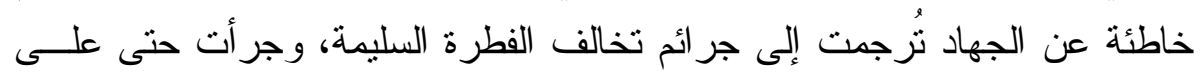
قتل المسلمين داخل المسجد الحر ام بمكة المكرمة التي لم يبح القتال فيها إلا ســـاعة

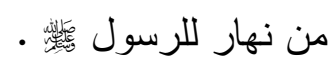

أدت هذه الفتاوى إلى إفساد المنشآت العامة التي تخدم مصالح المسلمين، و إهـــدار

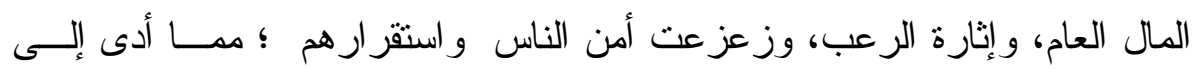

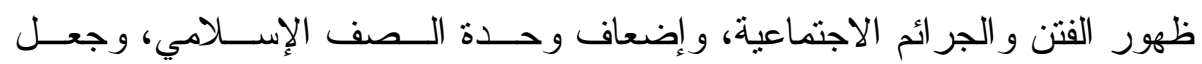

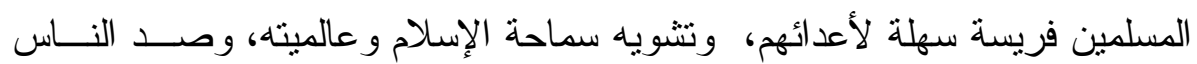

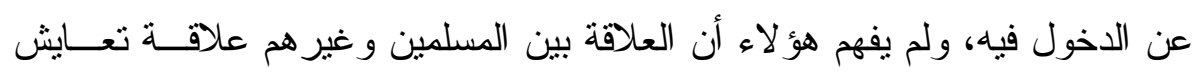

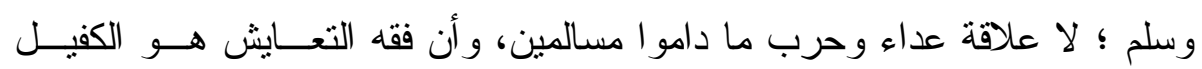

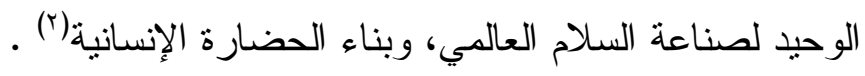




\section{الخاتمة}

الحمد لله الذي بنعمته تتم الصالحات، و الحمد لله على ما أنعم به علي من نعم عظيمــة، آلحة و آلاء جسيمة، وله الحمد على ما يسر لي وسهل من إكمال هذا البحث و إتمامه.

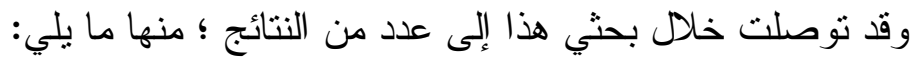

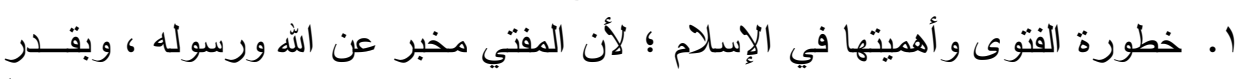

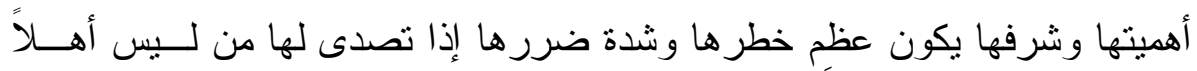
لها. r. إن ورع الصحابة - رضوان الله عليهم - و الأئمة المجتهدين مــن الـسلف عـن التصدي للفتوى مع عمهم دليل على أهمية الفتوى ومكانتها.

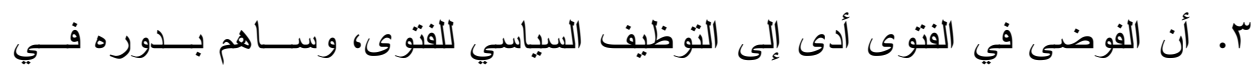

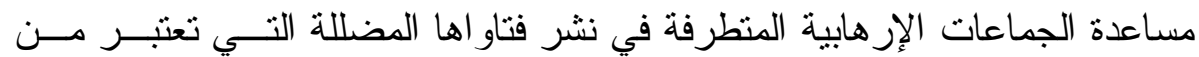
أخطر الفتاوى على الأمة الإسلامية.

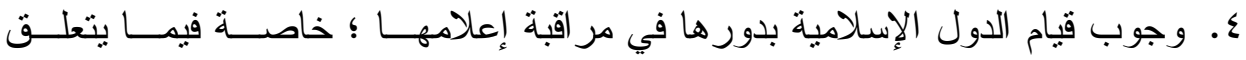
بموضوع الفتوى ؛ لحفظ الدين من عبث العابثني، ولعب الجاهلين.

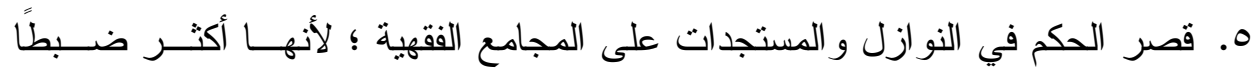

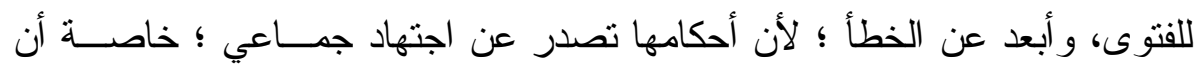
كثيرًا من النو ازل متداخلة وتحتاج إلى استشارة متخصصين في مجال الو اقعة.

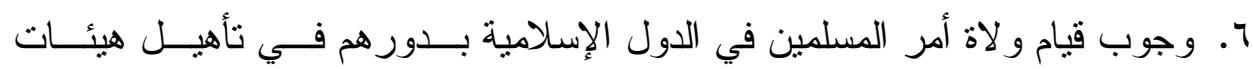

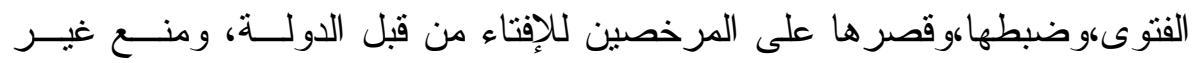
المؤهلين من التصدر للفتوى، ومعاقبتهم على ذلك.

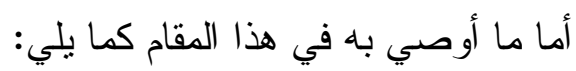
ا. إنشاء كليات أو معاهد شرعية لتأهيل المفتين مع التذريب العملي الذي يتيح لهم

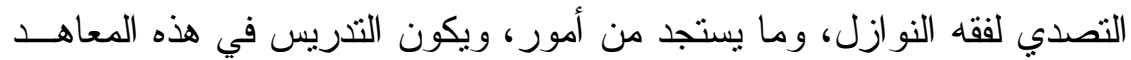
من قبل علماء العصر المشهود لهم بالعلم و الفقه.

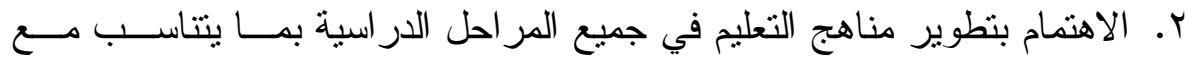
منطلبات الأمن الفقهي. 


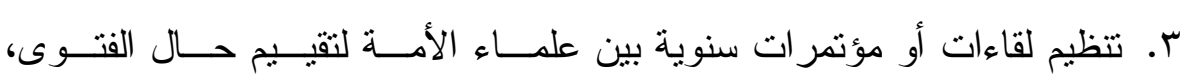
و النهوض بها.

ع. تثقيف الناس دينيًا، وتهيئتهم لقبول التعدد في الفتوى المبني على الاجتهاد، وأن ذلك من سعة الثريعة ورحمتها بالأمة.

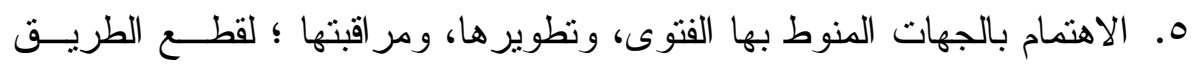
على الفوضى في الفتوى.

و أخير اً أسأل اله تعالى أن يكون فيما قدمت النفع و الفائدة لمن اطلع عليــه، وصـــلـى اله وسلم على سيدنا محمد، و على آله وصحبه أجمعين. 


\section{المر اجع}

ا. أثز الفتوى في الهحافظة على الهوية الإسلامية، للاكتور عبد الله محمد الطيار، بحث مقدم

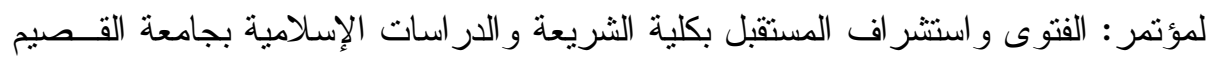

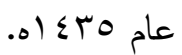

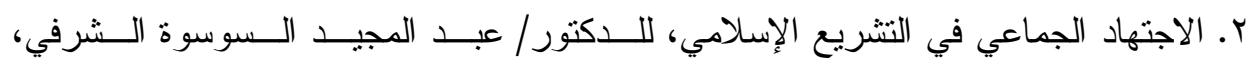

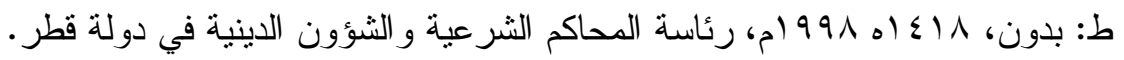

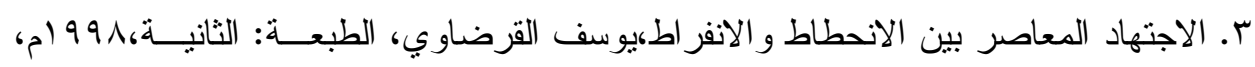
المكتب الإسلامي للطباعة و النشر . الاجن

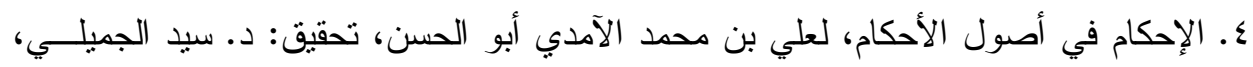

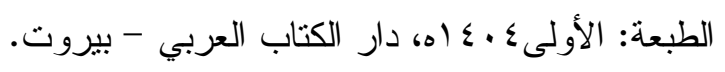

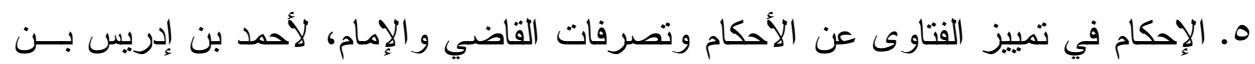

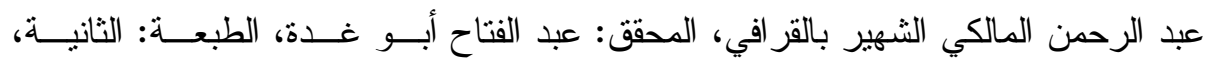

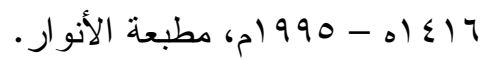
7. آداب الفتوى والمفتي و المستقتي، ليحي بن شرف النووي الدمشقي أبو زكريا، تحقق: بسام

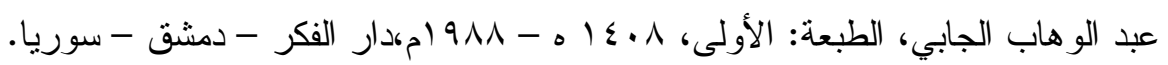

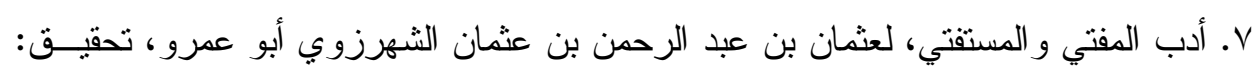

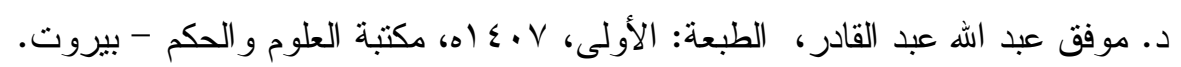

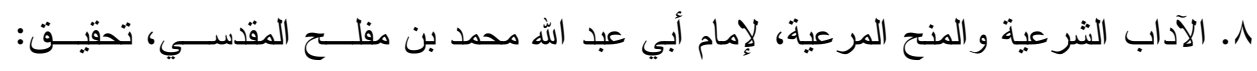

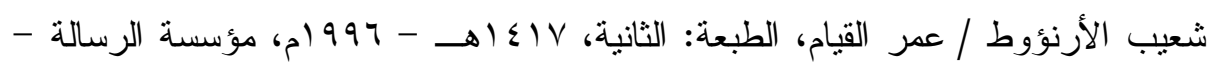
بيروت.

9. إعلام الموقعين عن رب العالمين، لأبو عبد الهه شمس الدين محمد بن أبي بكر بن أيوب بن

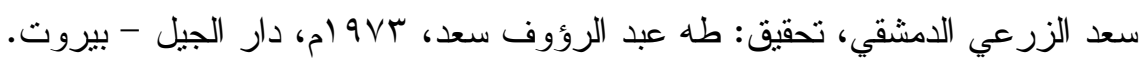

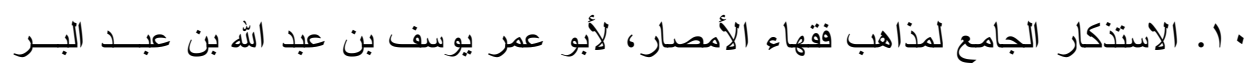

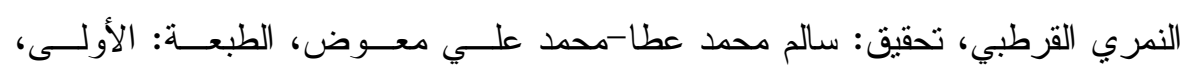

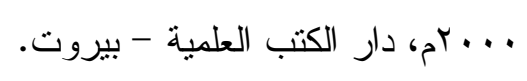

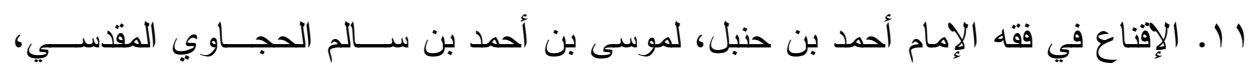
تحقيق: عبد اللطيف محمد موسى السبكي، طو تالف: بدون، دار المعرفة بيروت - لبنان. 


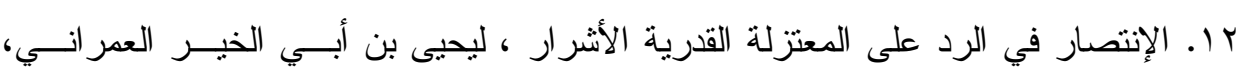

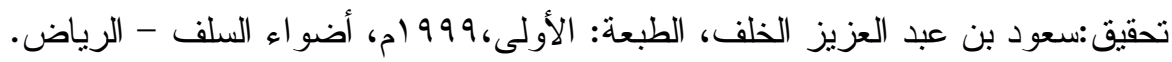

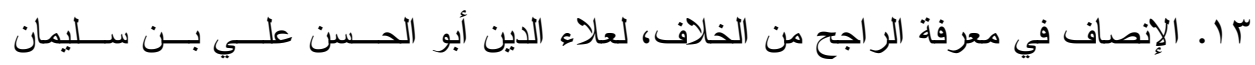

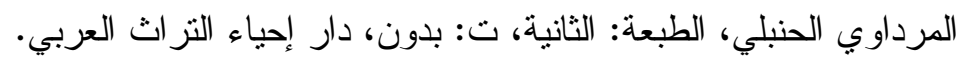

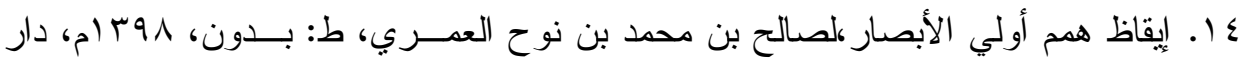

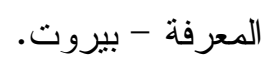

1. البحر المحيط في أصول الفقه، لبدر الدين محمد بن بهادر بن عبد اله الزركثي، تحقيق:

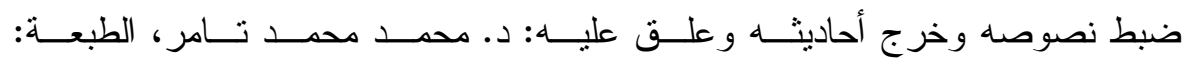

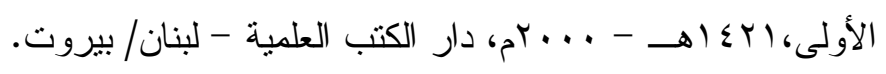

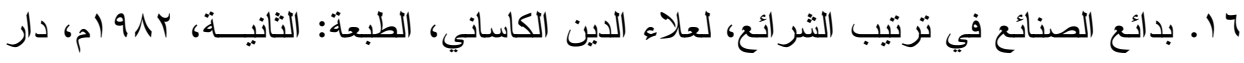

$$
\text { الكتاب العربي - بيروت. }
$$

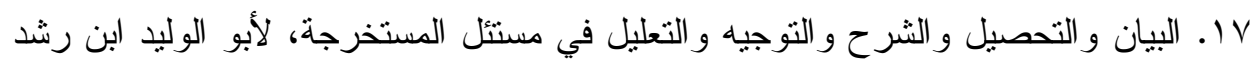

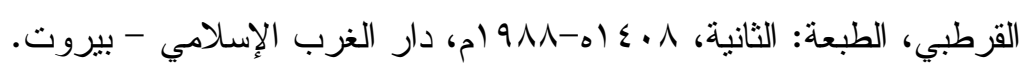

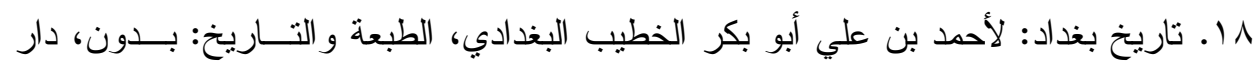

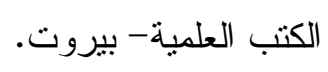

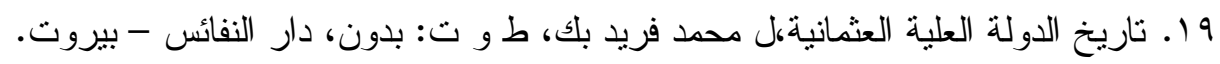

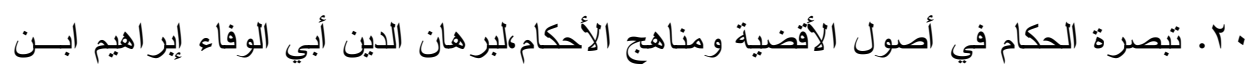

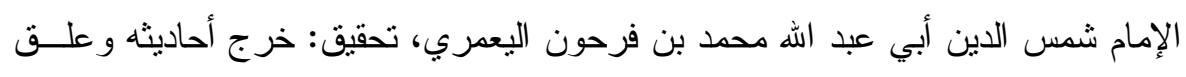

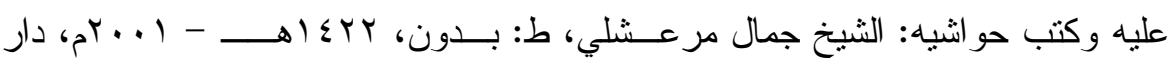

$$
\text { الكتب العلمية، لبنان - بيروت. }
$$

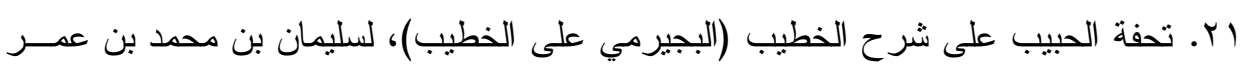

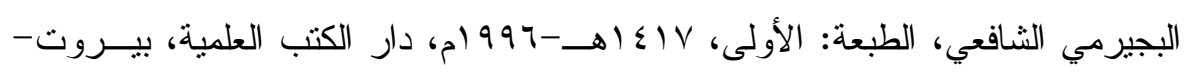
لبنان.

r. r. تغير الفتوى في الفقه الإسلامي، د. عبد الحكيم الرميلي، الطبعة: الأولــى، 17 • بام،دار الكتب العلمية.

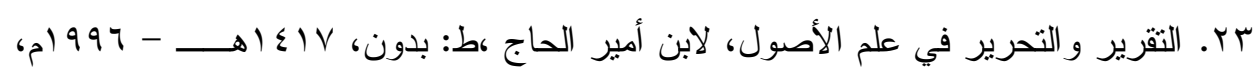
دار النشر: دار الفكر - بيروت. 
ع r. التمهيد لما في الموطأ من المعاني و الأسانيد، لأبو عمر يوسف بن عبد الله بن عبد البـر

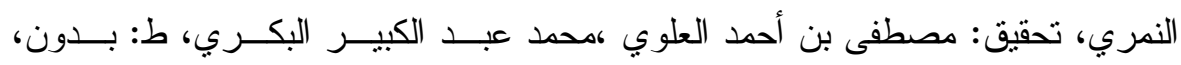

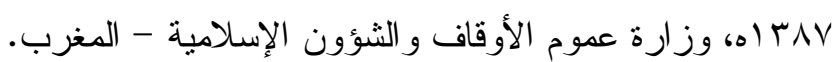

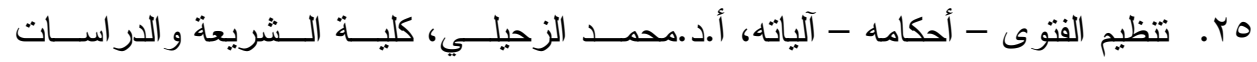
الإسلامية، جامعة الثارقة. جr. تيسير التحرير كلمحد أمين بن محمود البخاري المعروف بأمير بادشاه الحنفي،ط:بـــدون،

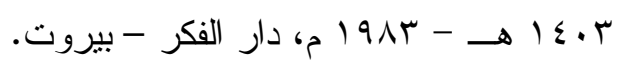

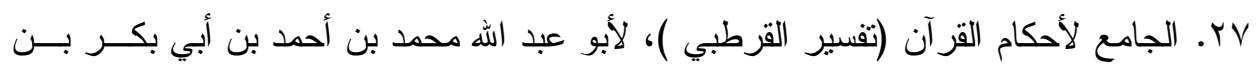

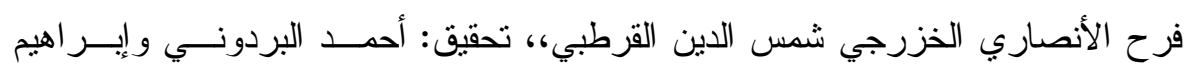

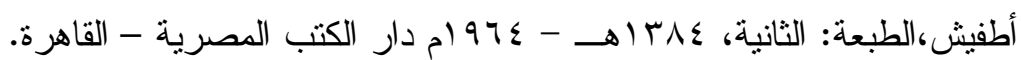

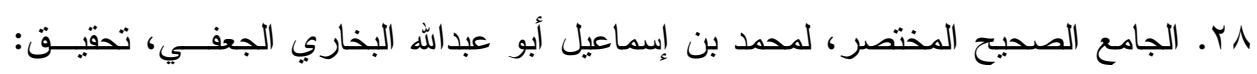

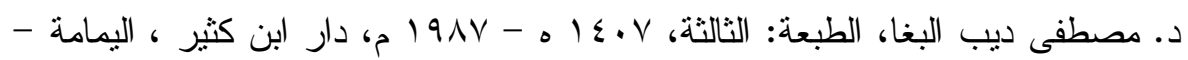
بيروت.

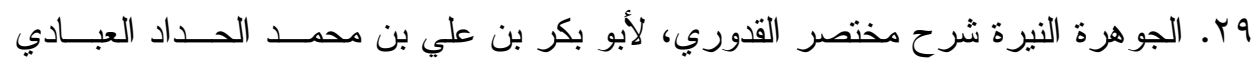

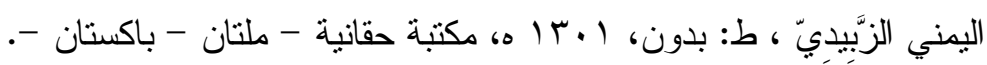

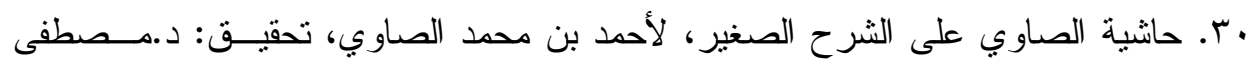

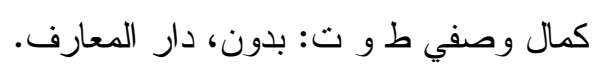

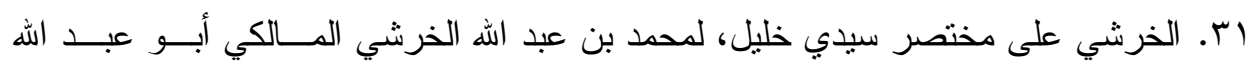
طو ت: بدون،دار الفكر للطباعة - بيروت. rr. الديباج المذهب في معرفة أعيان علماء المذهب، لإبر اهيم بن علي بن محمد بن فرحهـون

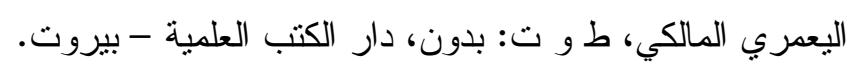

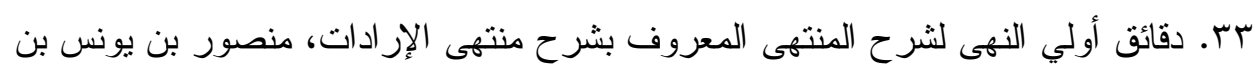

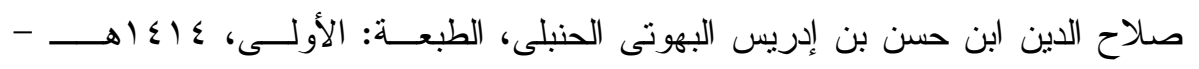

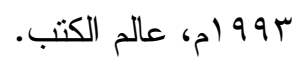

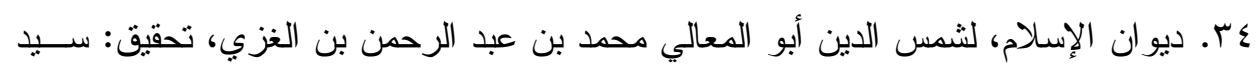

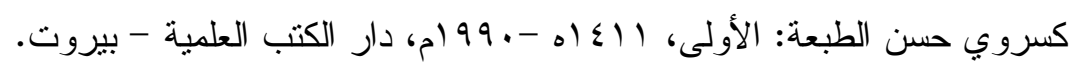


هr. سنن ابن ماجه، لمحمد بن يزيد أبو عبدالله القزويني، تحقيق: محمد فؤاد عبــــ البــاقي،

$$
\text { طو ت: بدون دار الفكر - بيروت. }
$$

جس. سنن أبي داود، لسليمان بن الأشعث أبو داود السجستاني الأزدي، تحقيق: محمد محيـي

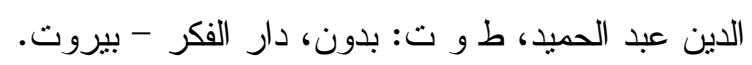

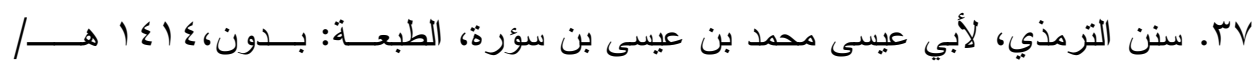

$$
\text { ع } 99 \text { م دار الفكر بيروت - لبنان. }
$$

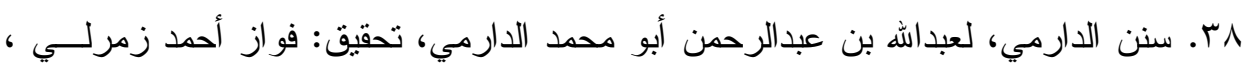

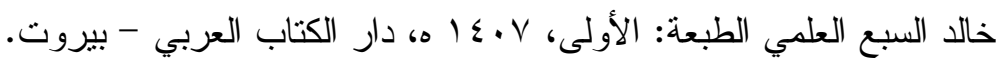

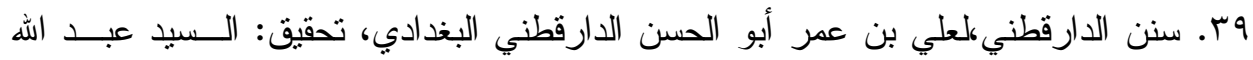

$$
\begin{aligned}
& \text { هاثم يماني المدني }
\end{aligned}
$$

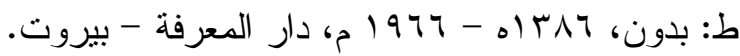

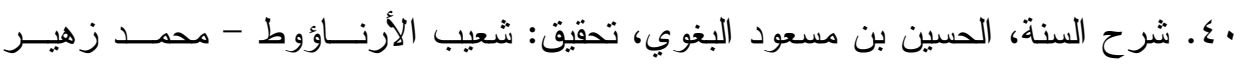

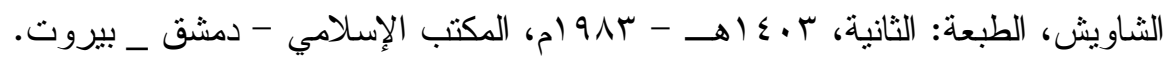

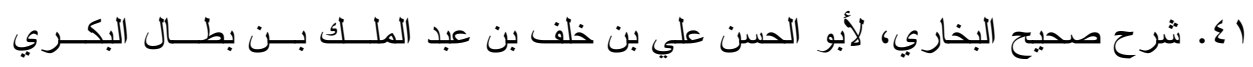

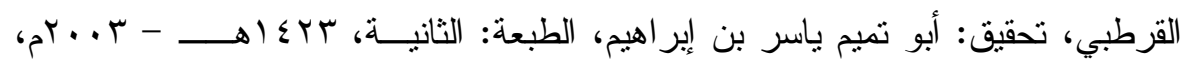

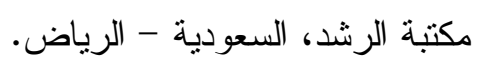

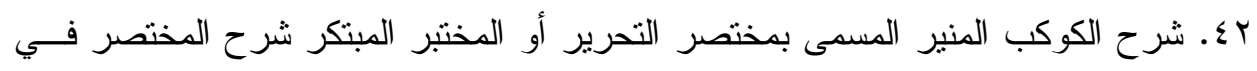

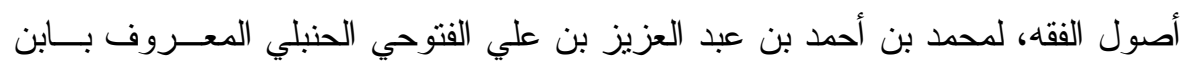

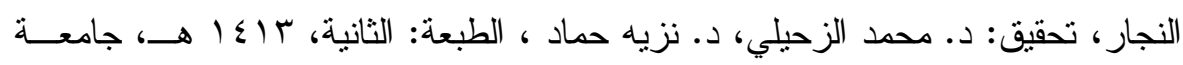

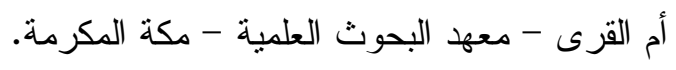

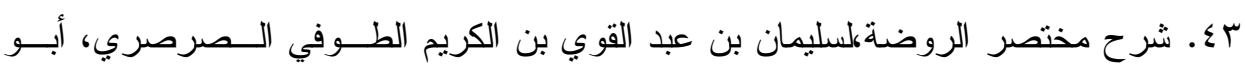

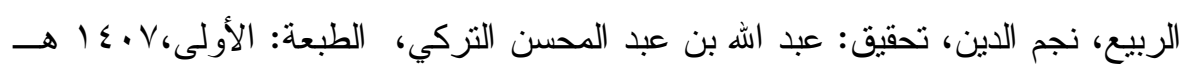

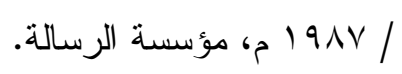

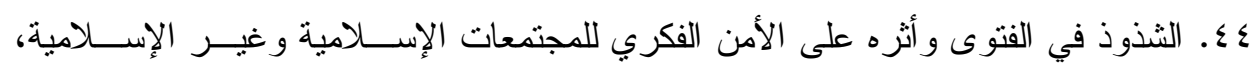

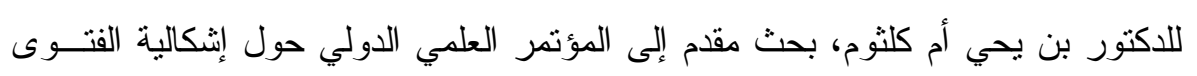

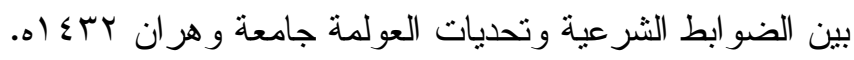


هـ. الثذوذ في الفتوى مفهومه ومعاييره، أسبابه و آثاره، لصلاح الدين سلامة فرج، مــؤتمر

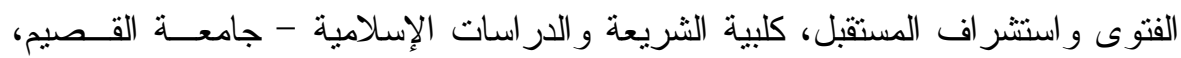
.0) $\leqslant$ ०

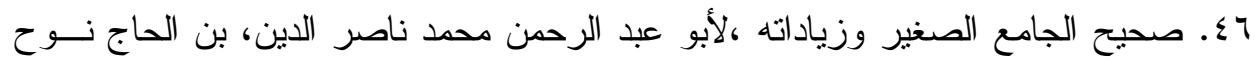

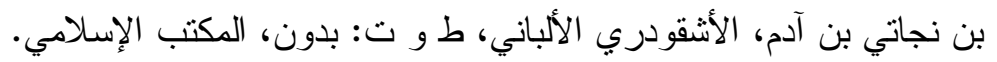

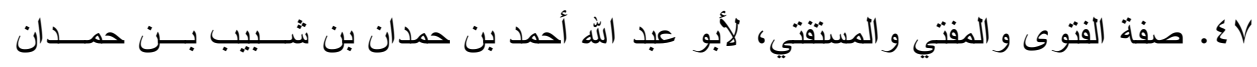

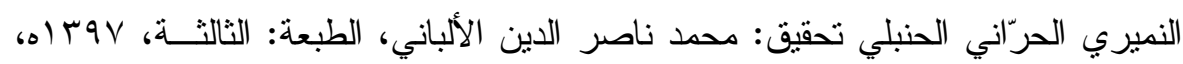

$$
\text { المكتب الإسلامي - بيروت. }
$$

^ــ ضو ابط الاجتهاد و الفتوى للاكتور أحمد علي طه، الطبعة: الأولى، ت: بدون، دار الوفاء للطباعة و النشر .

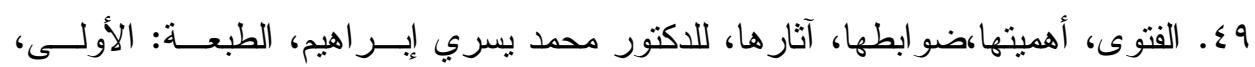

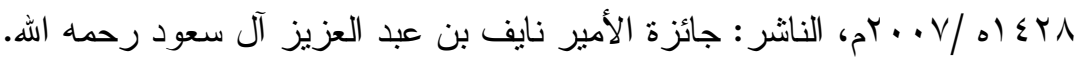

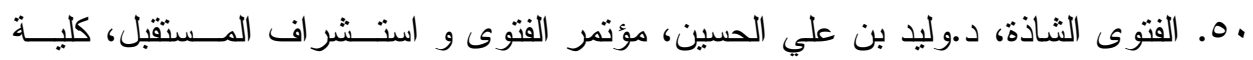

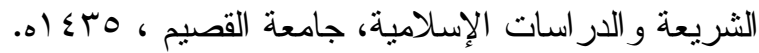

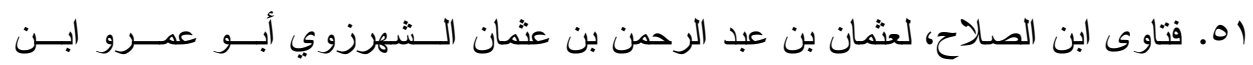

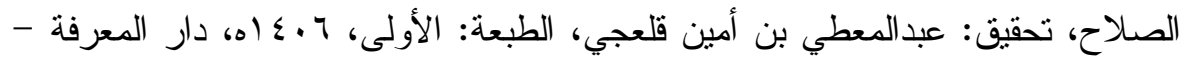

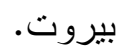

ro. الفتاوى الثاذه وخطورتها، أ. د عجيل جاســم النـشمي،بحث مقــدم لـــؤتمر الفتــوى

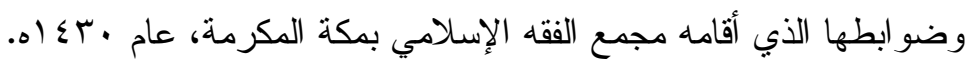

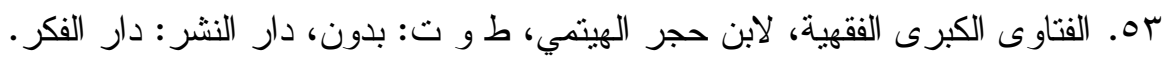

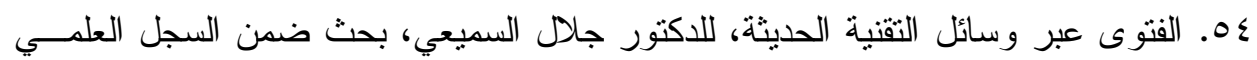

$$
\text { لمؤتمر الفتوى واستشر اف المستقبل. }
$$

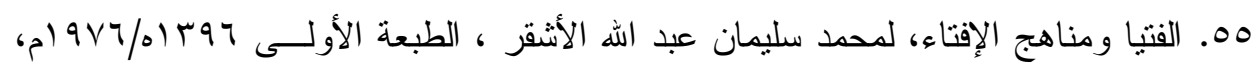
مكتبة المنار الإسلامية، الكويت. هـ الفروق أو أنوار البروق في أنواء الفروق (مع الهوامش )، لأبو العباس أحمد بن إدريس

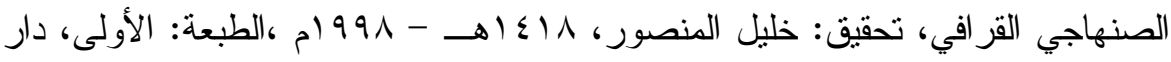

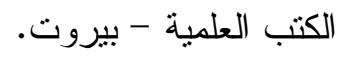




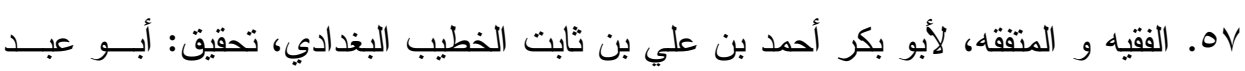

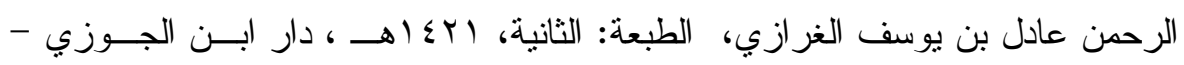
السعودية.

10. فقه المو ازنات الدعوية ( معالمه وضوابطه )، للاكتور معاذ محمد أبو الفتوح البيـانوني،

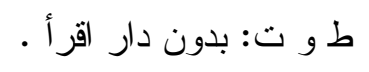

ه. قواطع الأدلة في الأصول، لأبو المظفر منصور بن محمد بن عبد الجبــار الـسمعاني،

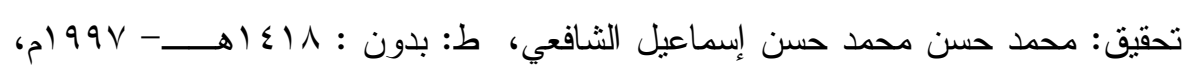
دار الكتب العلمية - بيروت.

• 7. الكتاب المصنف في الأحاديث و الآثار، لأبو بكر عبد الله بن محمد بن أبي شيبة الكوفي،

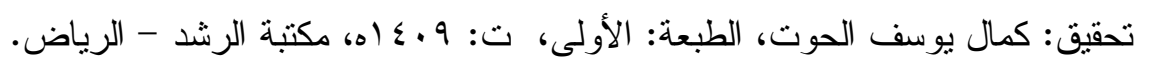

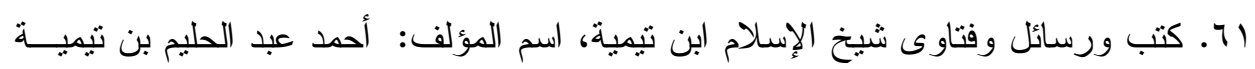

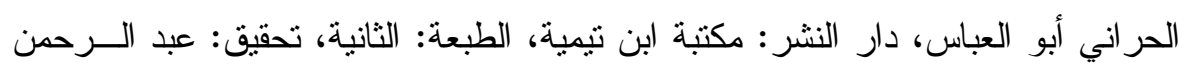
بن محمد بن قاسم العاصمي النجدي لوني

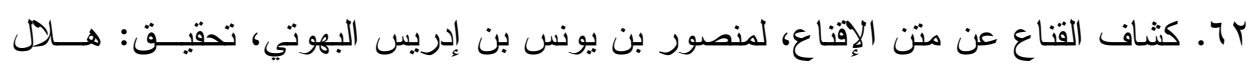
مصيلحي مصطفى هلا، ط: بدون، بـ؛ (ه، دار الفكر - بيروت.

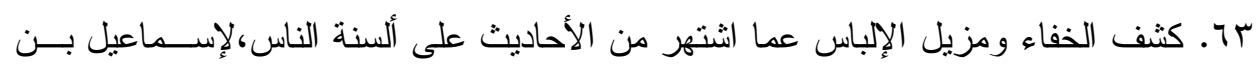

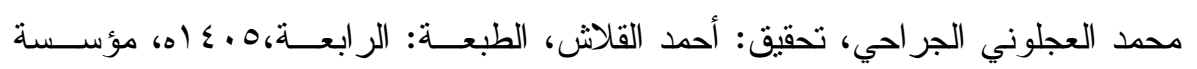

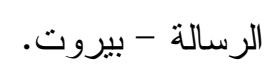

ع ا. كفاية الأخيارفي حل غاية الإختصار ، لتقي الدين أبي بكر بن محمد الحسيني الحـصيني

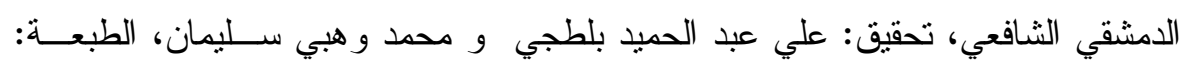

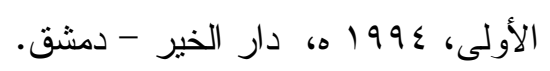

ه7. الكفاية في علم الرواية، لأحمد بن علي بن ثابت أبو بكر الخطيب البغدادي، تحقيق: أبـــو

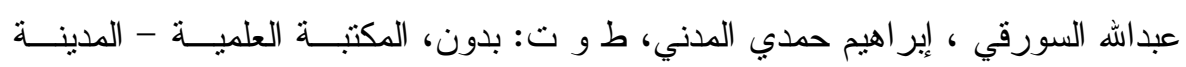
المنورة.

77. كنز العمال في سنن الأقو ال و الأفعال،علاء الدين علي المتقي بن حسام الــدين الهنــدي،

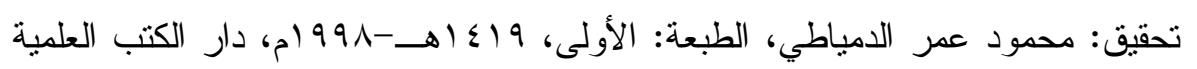


VIT. لسان العرب، لأبي الفضل جمال الدين محمد ابن منظور، طوت: بدون، دار المعسارف هـ مصر

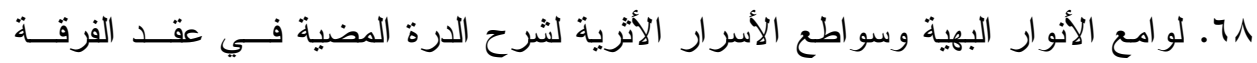

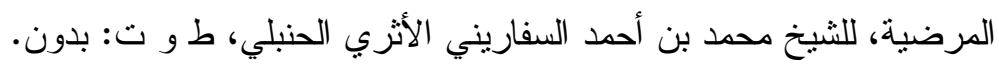

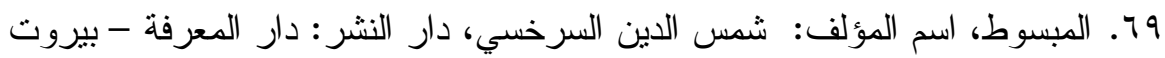

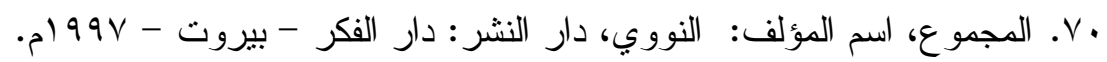
اV. المدخل إلى السنن الكبرى، لأحمد بن الحسين بن علي بن موسى البيهقي أبو بكر ، تحقق: محمد ضياء الرحمن الأعظمي، طو ت: بدون، دار الخلفاء للكتاب الإسلامي - الكويت.

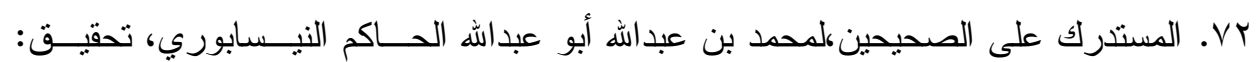

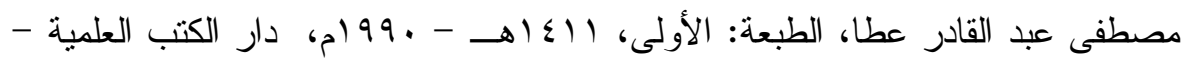
بيروت.

rV. المستصفى في أصول الفقه، حجة الإسلام محدد بن محمد الطوسي الغز الي، طبعة بو لاق الأولى.

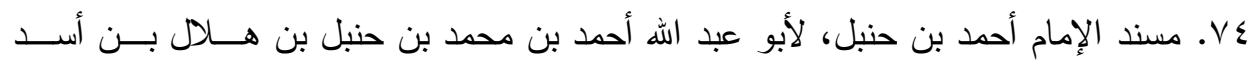

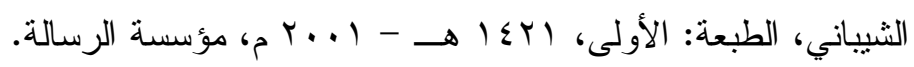
ه v. المسند الصحيح المختصر من السنن بنقل العدل عن العدل عن رسول الله صلى الله عليه

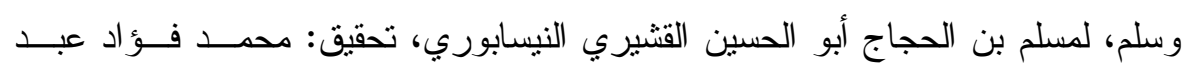

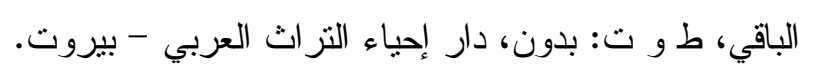

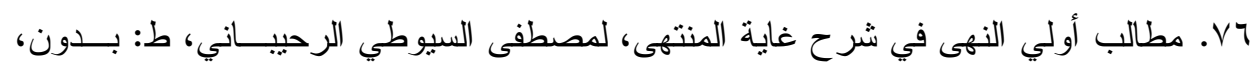

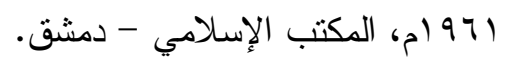

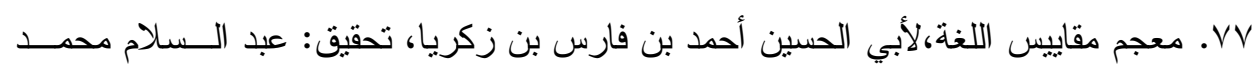

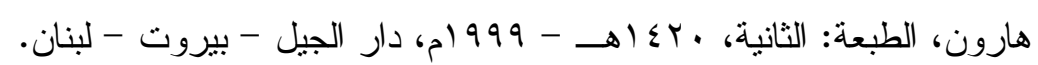

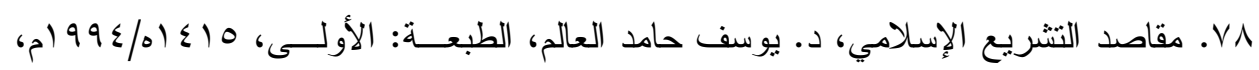
الدار العالمية للكتاب الإسلامي، المملكة العربية السعودية.

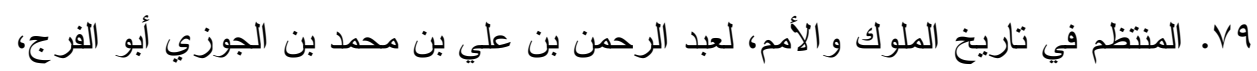

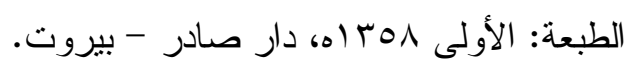


• ^. الموافقات، لإبر اهيم بن موسى بن محمد اللخمي الغرناطي الثهير بالثاطبي ، تحقيـق

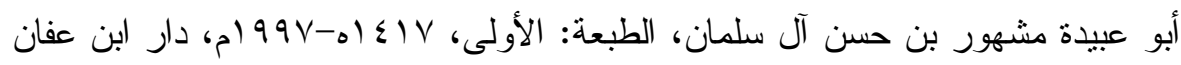
- السعودية.

ا 1. الموسوعة الفقهية الكوينتية، لوز ارة الأوقاف و الثشئون الإسلامية لدولة الكويـــ، الطبعــة

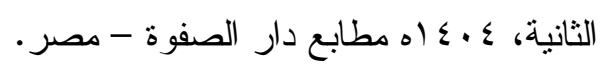

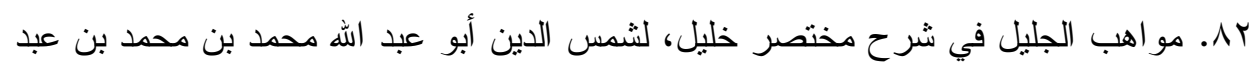

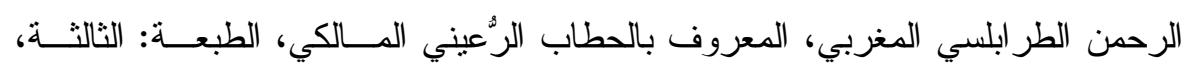

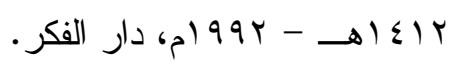

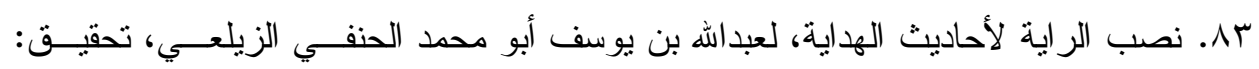

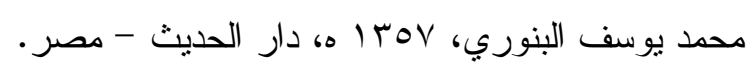

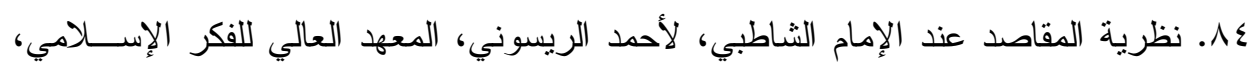

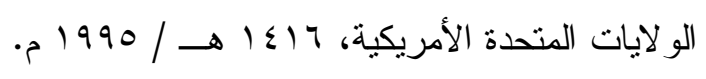

المواقع الإكترونية:

ا. موقع الألوكة الأكترونه:

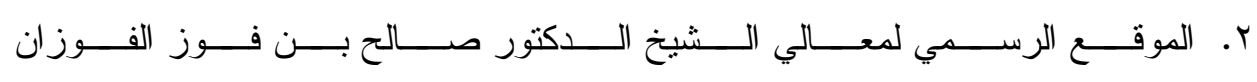
.ht t ps://www.al f awzan.af .org.sa r. الموقع الرسمي لهيئة كبار العلماء

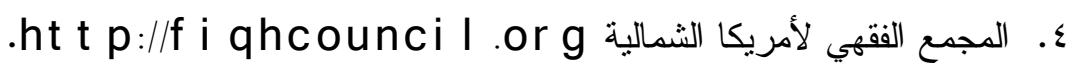

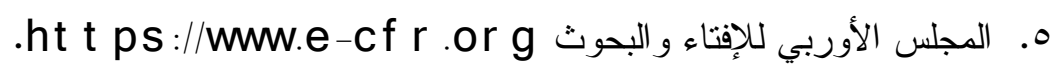

